Check for updates

Cite this: Nat. Prod. Rep., 2017, 34, 1359

Received 30th July 2017

DOI: 10.1039/c7np00041c

rsc.li/npr

\section{The chemistry and chemical ecology of nudibranchs}

\author{
Lewis J. Dean and Michèle R. Prinsep (iD *
}

Covering: up to the end of February 2017

Nudibranchs have attracted the attention of natural product researchers due to the potential for discovery of bioactive metabolites, in conjunction with the interesting predator-prey chemical ecological interactions that are present. This review covers the literature published on natural products isolated from nudibranchs up to February 2017 with species arranged taxonomically. Selected examples of metabolites obtained from nudibranchs across the full range of taxa are discussed, including their origins (dietary or biosynthetic) if known and biological activity.
Introduction

Taxonomy

The origin of nudibranch natural products

Scope of review

Dorid nudibranchs

5.1 Bathydoridoidea

5.1.1 Bathydorididae

5.2 Doridoidea

5.2.1 Actinocyclidae

5.2.2 Cadlinidae

5.2.3 Chromodorididae

5.2.4 Discodorididae

5.2.5 Dorididae

5.3 Onchidoridoidea

5.3.1 Onchidorididae

5.3.2 Goniodorididiae

5.4 Phyllidioidea

5.4.1 Dendrodoridae

5.4.2 Phyllidiidae

5.5 Polyceroidea

5.5.1 Aegiridae

5.5.2 Hexabranchidae

5.5.3 Polyceridae

6 Cladobranchs

6.1 Aeolidioidea

6.1.1 Aeolidiidae

6.1.2 Facelinidae

6.2 Arminoidea

6.3 Doridoxoidea

$6.4 \quad$ Fionoidea

$\begin{array}{ll}\text { 6.5 } & \text { Flabellinoidea } \\ 6.6 & \text { Tritonioidea } \\ 6.6 .1 & \text { Tethydidae } \\ \text { 6.6.2 } & \text { Tritoniidae } \\ 6.7 & \text { Unassigned families } \\ 6.7 .1 & \text { Charcotiidae } \\ 6.7 .2 & \text { Dotidae } \\ 6.7 .3 & \text { Proctonotidae } \\ 7 & \text { Nematocysts and zooxanthellae } \\ 8 & \text { Conclusions } \\ 9 & \text { Conflicts of interest } \\ 10 & \text { Acknowledgements } \\ 11 & \text { References }\end{array}$

\section{Introduction}

Nudibranchs, often called sea slugs or more poetically, "butterflies of the sea", ${ }^{1}$ are a diverse group of marine gastropod molluscs, representing over 4700 known species. ${ }^{2}$ After shedding their shells as larvae, nudibranchs thereafter remain shell-less; indeed the name nudibranch literally translates to "naked gill", a reference to the exposed cerata on the backs of many species. ${ }^{3}$ Whilst essentially blind, nudibranchs perceive their environment through chemosensory interactions with two specialised rhinophores on their heads. ${ }^{3,4}$ These carnivores are important consumers in benthic communities, feeding mostly upon sessile organisms, (sponges, cnidarians, tunicates and bryozoans), although some species hunt other nudibranchs. Both specialist and generalist feeders are known and can be found in practically all oceans. ${ }^{3}$

Having lost the physical protection of a shell, nudibranchs often utilise chemical defences to deter predators. ${ }^{3}$ Given that their typical prey species are some of the most prolific producers of natural products, ${ }^{5}$ it is perhaps unsurprising to 

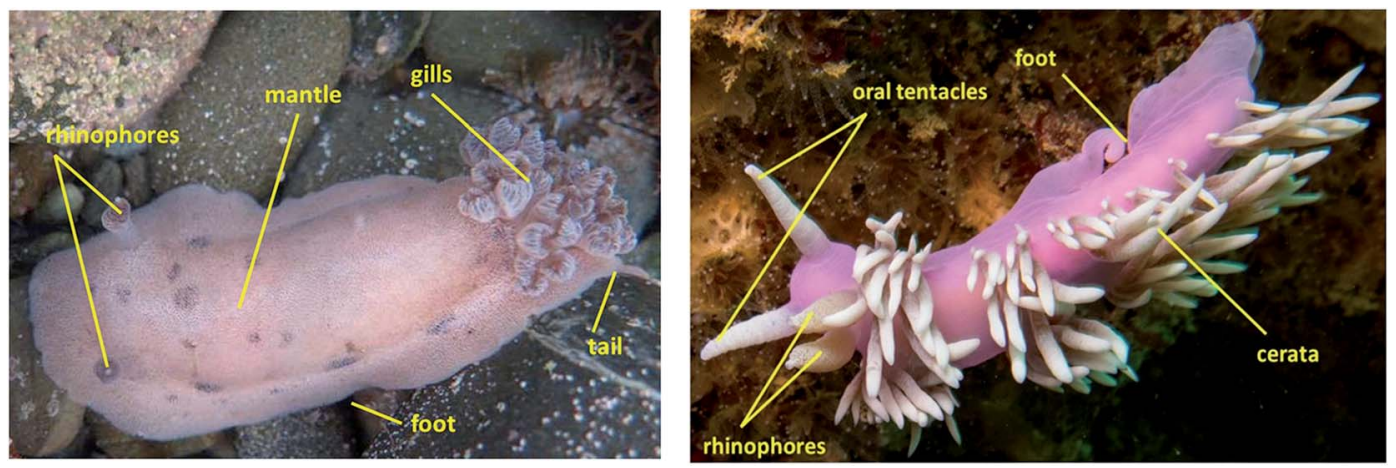

Fig. 1 General morphology of a dorid nudibranch (Alloiodoris lanuginata) (left), highlighting the dorsal gill plumage and an aeolid nudibranch (Jason mirabilis) with characteristic cerata (right). Note the presence of rhinophores on both. Photographs courtesy of Tracey Bates. (After Picton and Morrow, 2006).3

find that many nudibranchs are known to sequester these defences. ${ }^{6}$ The vibrant colours associated with many nudibranch species are often correlated with those of their prey, ${ }^{6}$ however, de novo production of defences is also known. ${ }^{7}$ Nudibranchs have thus attracted many natural product researchers due to the potential for discovery of bioactive metabolites, in conjunction with the chemical ecological interactions between predator and prey that exist for many species.

\section{Taxonomy}

Broadly speaking, nudibranchs can be separated into two distinct groups based on their general morphology (Fig. 1) ${ }^{3}$ and digestive glands; dorids and aeolids. ${ }^{7}$ Dorid nudibranchs (clade: Euctenidiacea) have an intact digestive gland ${ }^{7}$ and are distinguished by a feather-like plume of gills on their dorsal side, circling the anus. ${ }^{3}$ They also commonly feature discrete pockets, bumps and other distortions, on their skin known as mantle dermal formations (MDFs), in which bioactive defence chemicals are typically stored., ${ }^{3,8}$ Aeolid nudibranchs (clade: Cladobranchia) have a branched digestive gland ${ }^{7}$ and lack gills. ${ }^{3}$ They are characterised by the presence of dorsal projections known as cerata, which function in place of gills by facilitating gas exchange through the epidermis. ${ }^{3}$ In many aeolid species, the digestive tract also extends into the cerata and the tips often contain cnidosacs; stinging cells absorbed from prey species that are used for the nudibranch's own defence. ${ }^{3}$

Strictly speaking, a branched digestive gland is indicative of a non-dorid nudibranch, known as a cladobranch ${ }^{7}$ and true aeolids are only those belonging to the parvorder Aeolidida (Fig. 2), the only nudibranchs to possess cnidosacs. ${ }^{79}$ However, many of the non-dorid nudibranchs are said to be aeolid-like as they possess cerata, or cerata-like projections, instead of gills. ${ }^{3}$ Others do possess gills, often tucked between the mantle and foot, but they bear little resemblance to the dorsal plumes of dorids. ${ }^{3}$

The classification of nudibranchs is far from settled. There have been a number of taxonomic revisions in the past, ${ }^{10-12}$ the one presented here being that currently used as in WoRMs. ${ }^{13} \mathrm{~A}$ clear distinction between dorid and non-dorid nudibranchs is well established, although a number of cladobranch families have yet to be assigned to an appropriate superfamily. ${ }^{13}$

Molecular studies are offering new insights into phylogenetic relationships. A relatively recent report analysing RNA

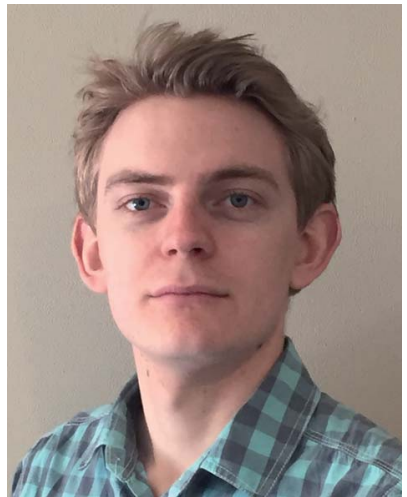

Lewis Dean obtained his BSc(Hons) at the University of Waikato in 2016, completing his research dissertation on the natural products of New Zealand nudibranchs. A past winner of a prestigious University of Waikato Sir Edmund Hillary Scholarship, he was recently awarded a University of Waikato Doctoral Scholarship and is currently undertaking a PhD under the chief supervision of Michèle Prinsep, focusing on the isolation and characterisation of bioactive metabolites from New Zealand marine algae.

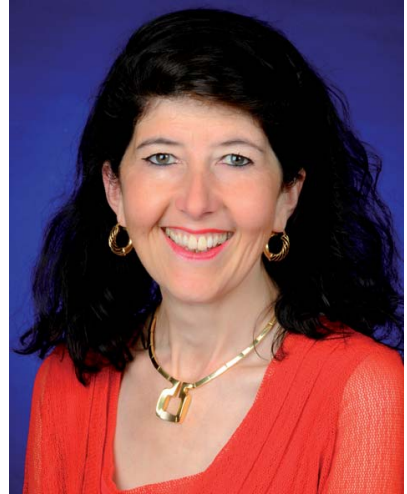

Michèle Prinsep received her BSc(Hons) and PhD degrees from the University of Canterbury, where she studied the isolation and structural elucidation of biologically active secondary metabolites from sponges and bryozoans under the supervision of Professors Blunt and Munro. She undertook postdoctoral research on cyanobacteria with Richard Moore at the University of Hawaii before returning to New Zealand to take up a lectureship at the University of Waikato, where she is currently an Associate Professor. 


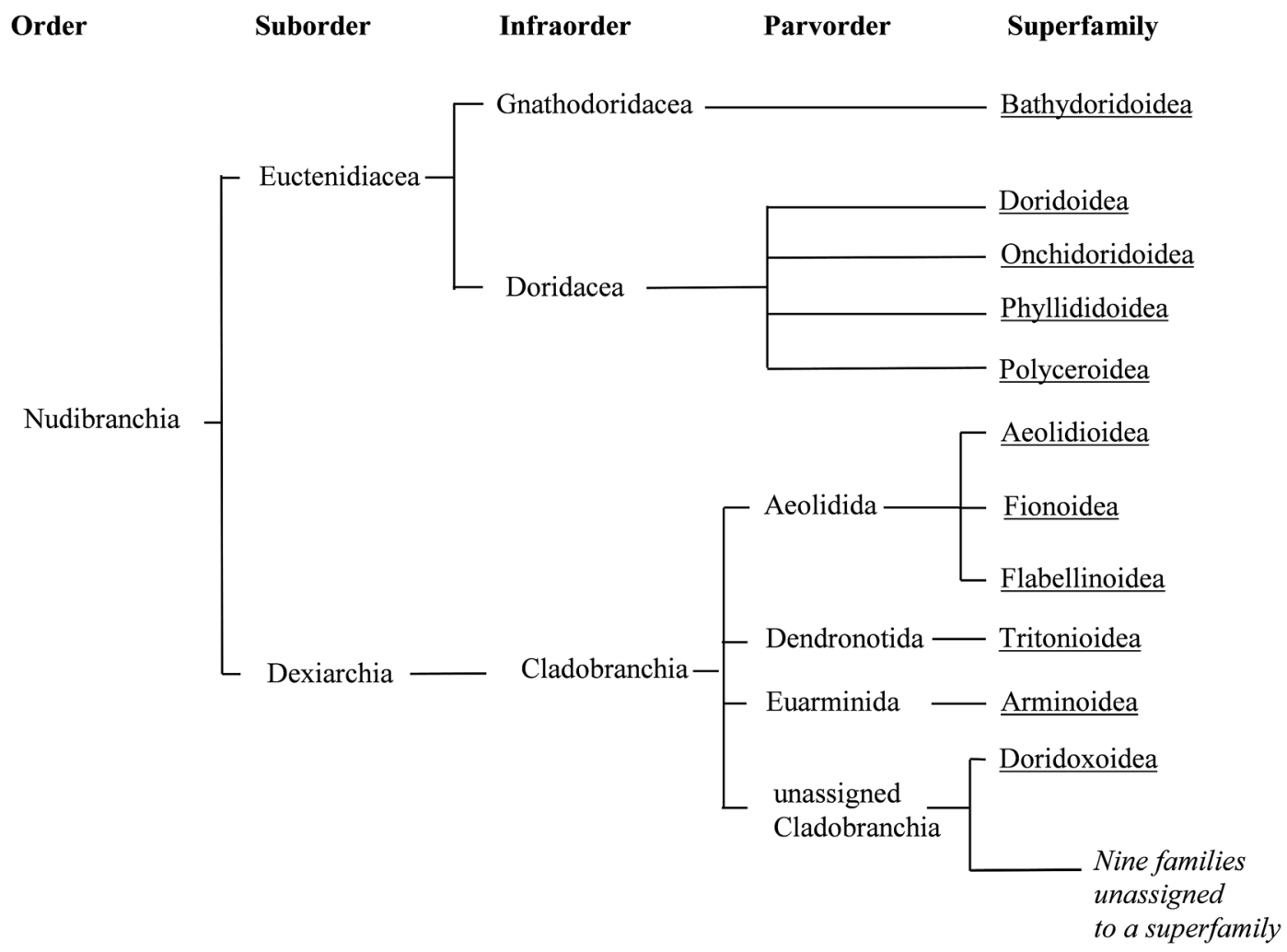

Fig. 2 Phylogenetic relationships between the taxonomic divisions currently recognised for Nudibranchia, and that are used in this review. Branches are terminated with superfamilies (underlined), whilst the roots represent taxonomic divisions (as used in WoRMS ${ }^{13}$ ).

sequence data, attempted to reconcile the groupings within Cladobranchia. ${ }^{14}$ Whilst many of the relationships highlighted in past classifications ${ }^{12}$ are retained, some new clades have been suggested (although unnamed), incorporating some of the previously unassigned families. However, this analysis is by no means conclusive since only 10 of the 32 families currently recognised were investigated. ${ }^{14} \mathrm{~A}$ similar study analysed the mitochondrial and nuclear genes of the Doridoxa genus (the only genus in the current superfamily Doridoxoidea). ${ }^{15}$

The changes proposed by the above studies serve to highlight the ever evolving nature of taxonomy. This can lead to confusion for anyone attempting to navigate the literature covering nudibranch natural products, as invariably one will come across outdated phylogenetic relationships as well as old or repurposed taxonomic names. As an example, Doridacea is now recognised as an Infraorder within Euctenidiacea representing a subdivision of dorid nudibranchs, ${ }^{13}$ whereas historically it was used as a suborder covering all dorids. ${ }^{3,7}$ Some species may also have been renamed and others folded into one another. This confusion has in some, thankfully rare, cases extended to a non-nudibranch sea slug (Pleurobranchaea meckeli) being reported as such. ${ }^{16}$

\section{The origin of nudibranch natural products}

Given that both sequestration and de novo synthesis of natural products are known in nudibranchs, it is rarely immediately clear if an isolated metabolite is of dietary origin. Feeding experiments with isotopically labelled precursors, are the only accepted procedures to prove biosynthesis of a metabolite. ${ }^{17}$ Unfortunately, the low uptake of feedstock by many marine organisms often forces the use of radioactive isotopes. ${ }^{17}$ Advances in nuclear magnetic resonance (NMR) spectroscopy have improved sensitivity and thus stable isotope experiments are increasingly becoming viable options, yet the cost of precursors, radioactive or stable, combined with the costs of very sensitive NMR instruments has inevitably restricted the use of feeding experiments in nudibranch studies.

There are many cases in the literature where de novo synthesis has been assumed, despite no feeding experiments being conducted. As the digestive glands of all nudibranchs are the source of nutrient distribution throughout the organism, it stands to reason that if a natural product is found therein, it is likely of dietary origin. ${ }^{7}$ Conversely if a metabolite is only present in the skin or mantle, and not in the viscera of a nudibranch, then it is probable that the compound is either biosynthesised in full or secondarily modified. ${ }^{7}$ Likewise, the absence or presence of the same, or structurally related, metabolite(s) in possible food species are also used to argue for biosynthesis or sequestration respectively. ${ }^{18}$ It has been further reasoned that any species of nudibranch that synthesises its own metabolites should consistently possess all metabolites, across all geographic collections. ${ }^{18}$ Species known to show variation in their natural products, especially from differing locations, may be indicative of metabolite sequestration..$^{18}$ In addition, as one of the evolutionary advantages of de novo 
synthesis is to liberate a nudibranch from a singular food source, specialist feeders may be more likely to sequester metabolites. ${ }^{7,18}$

\section{Scope of review}

There have been a number of excellent reviews of nudibranch chemistry over the years, including reviews on chemical ecology, ${ }^{19-21}$ chemical defence ${ }^{7,22,23}$ and bioactive metabolites. ${ }^{24,25}$ Many focus on specific groups of metabolites such as diterpenes ${ }^{26}$ terpenoids, ${ }^{27}$ cyanide and isothiocyanates ${ }^{28}$ and isocyanides ${ }^{29}$ (but all also include other marine invertebrates). A number of these reviews are regional in their focus, dealing with nudibranchs and other molluscs found in New Zealand, ${ }^{30,31}$ Australia, ${ }^{31,32}$ North America, ${ }^{33}$ Japan, ${ }^{34}$ Africa, ${ }^{35}$ South America ${ }^{35}$ and Antarctica. ${ }^{35}$

The annual review of marine natural products that appears in Natural Product Reports has a section on molluscs ${ }^{36 a-f}$ but given the wide scope of this review, there is no capacity to discuss nudibranchs in any detail or in a comprehensive manner over a considerable time period. There have only been three relatively recent reviews that deal with nudibranch chemistry, but two of these are not specific to nudibranchs (focus respectively on the terpene chemistry of marine molluscs ${ }^{37}$ and marine molluscs as a source of antiviral drugs $\mathrm{s}^{38}$ ) and the third is limited in scope (deals with lipids and fatty acids of nudibranchs but only eight species were examined). ${ }^{39}$

This current review focusses on the chemistry and chemical ecology of nudibranchs. It is arranged taxonomically and species are ordered as per their superfamily in the World Register of Marine Species (WoRMS) ${ }^{\mathbf{1 3}}$ to highlight both the different and similar defensive strategies adopted by the various clades. Species are referred to and ordered by the name used in the original publication but where a taxonomic revision has taken place, the correct name is given in Table 1 and noted in brackets in the text. In each section, a selection of representative, significant or otherwise interesting, nudibranch natural products are discussed, including their origins (dietary or biosynthetic) if known and biological activity.

\section{Dorid nudibranchs}

\subsection{Bathydoridoidea}

5.1.1 Bathydorididae. Bathydoridoidea is a small superfamily of deep water nudibranchs containing only the family Bathydorididae, comprised of one genus, Bathydoris. It has received little attention from natural product chemists, presumably due to difficulties in collecting specimens. A single investigation of one species has been reported to date. Hodgsonal (1), a novel, drimane sesquiterpene was isolated from the mantle of Bathydoris hodgsoni ${ }^{\mathbf{4 0}}$ and was the first known 2substituted drimane sesquiterpene of marine origin. ${ }^{\mathbf{4 0 , 4 1}}$ The distribution of 1 among individual $B$. hodgsoni specimens collected from various sites was found to be reasonably consistent and it was only detected on the extremities of the nudibranch and not in the viscera. Given that the stomach contents of $B$. hodgsoni indicated that this species is a generalist and opportunistic feeder, it was suspected that 1 is de novo synthesised. ${ }^{\mathbf{4 1}}$ In experiments, 1 deterred feeding in a potential starfish predator (Odontaster validus) at natural concentrations, highlighting its probable use as a defence allomone. ${ }^{41}$<smiles>CC(=O)OC[C@H]1C[C@@]2(C)[C@@H](CC=C1C=O)C(C)(C)C[C@H]2OC(C)=O</smiles>
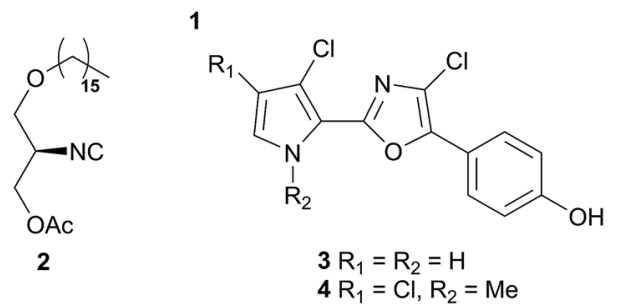

\subsection{Doridoidea}

Comprising five families, Doridoidea is by far the most studied nudibranch superfamily in terms of species, genera and metabolites reported. Searching within the MarinLit database ${ }^{\mathbf{4 2}}$ for natural products investigations into nudibranchs (Taxonomy filter: Phylum-Mollusca; Article free text filter: nudibranch) reveals 152 records (as of 28 February 2017). Of these, 80 concern species of Doridoidea (56\%).

5.2.1 Actinocyclidae. Actinocyclidae is a small family comprising two genera (Actinocyclus and Haliaxa) and only one study has been conducted on a species in this family. An isonitrile lipid, actisonitrile (2) was obtained from the mantle of a South China Sea specimen of Actinocyclus papillatus as the major component. Total synthesis was achieved and both enantiomers exhibited moderate cytotoxicity to a mammalian cell line, which, along with the selective distribution of $\mathbf{2}$, implies a likely defensive function for the metabolite. ${ }^{43}$

5.2.2 Cadlinidae. The Cadlinidae family comprises two genera (Aldisa and Cadlina) and the chemistry of representatives of both has been studied. An Indian collection of Aldisa andersoni was the source of some members of the phorbazole family of metabolites, ${ }^{44}$ including the new 9-chloro-phorbazole D (3) and N1-methyl-phorbazole A (4), which co-occurred with known phorbazoles A, B and D, previously obtained from the sponge Phorbas aff. clathrata. ${ }^{45}$ Although found mainly on the exterior of $A$. andersoni, the compounds were also present in the digestive organs of the mollusc, reinforcing the high probability that these compounds were sequestered from a Phorbas sponge, although none were observed near the collection site. ${ }^{\mathbf{4 4}}$ Phorbazole A, 3 and $\mathbf{4}$ deterred feeding by the shrimp Palaemon elegans and both 3 and 4 exhibited cytostatic effects against several human tumour cell lines (HTCLs). ${ }^{\mathbf{4}}$

Two steroidal acids, 3-oxo-chol-4-ene-24-oic acid (5) and its unsaturated analogue (6), were isolated from Aldisa sanguinea cooperi $^{\mathbf{4 6}}$ (Aldisa cooperi ${ }^{359}$ ). Cholestenone (7), an alkyl derivative of 5 and 6 was also present in the extract. A. cooperi was consistently found feeding upon the sponge Anthoarcuata 
graceae, which, whilst lacking $\mathbf{5}$ and $\mathbf{6}$, was found to contain $\mathbf{7}$ as one of its major metabolites. Cholestenone, 7, proved to be inactive in feeding experiments whereas $\mathbf{5}$ was an effective inhibitor of feeding behaviour (common goldfish). This indicated that $A$. cooperi was obtaining an inactive metabolite from its diet and modifying it to provide a defence against predators. ${ }^{46}$ It has been suggested that another steroidal metabolite, 24-norchol-4-ene-3,22-dione (8), isolated from the related nudibranch $A$. smaragdina may also be secondarily modified from 7 (ref. 47) or alternatively, result from the $\beta$-oxidation and subsequent decarboxylation of $\mathbf{5}$. However, these suggestions were tentative since no steroidal precursors were noted in the observed prey species Phorbas fictitius. ${ }^{47}$

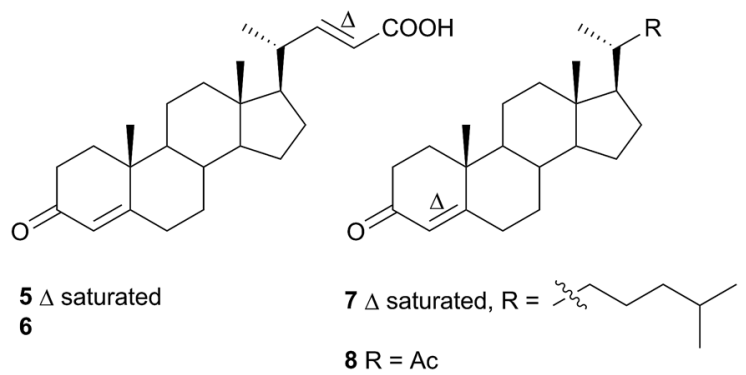

A nudibranch that has attracted significant interest is Cadlina luteomarginata, as it is one of only two species of nudibranchs known to both sequester prey metabolites and biosynthesise its own natural products ${ }^{\mathbf{4 8}}$ (the other, Dendrodoris grandioflora, will be discussed below). To date, 38 terpenoid metabolites, with 22 carbon skeletons, representing monoterpenes, ${ }^{\mathbf{4 9}}$ sesquiterpenes, ${ }^{49-51}$ diterpenes, ${ }^{52,53}$ sesterterpenes $^{54}$ and degraded sesterterpenoids ${ }^{51,55}$ and diterpenoids ${ }^{53,56}$ have been isolated from $C$. luteomarginata. ${ }^{57}$ Examples of the sequestered metabolites are glaciolide (9) ${ }^{56}$ and cadlinolide A $(\mathbf{1 0})^{\mathbf{5 3}}$ from the sponge Aplysilla glacialis, and ansellone A $(\mathbf{1 1})^{\mathbf{5 4}}$ from a prey sponge of the Phorbas genus. Their ecological roles are not well defined, ${ }^{57}$ but $\mathbf{1 1}$ has been shown to be moderately activating towards cellular processes that use the cyclic adenosine monophosphate (cAMP) signal pathway. ${ }^{54}$

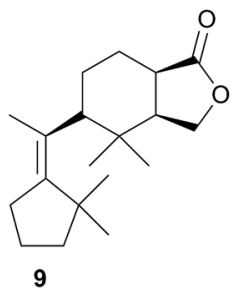

9

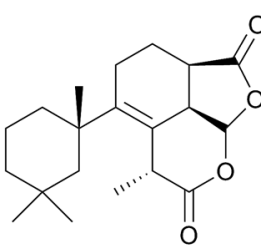

10

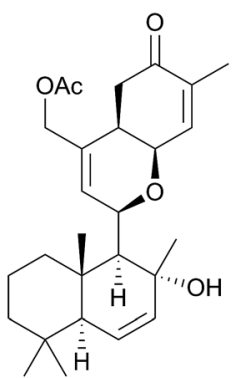

11
Terpenoid biosynthesis in C. luteomarginata was suspected when all previously analysed individuals from a British Columbian (Canadian) study consistently possessed the same three terpenoids. ${ }^{58}$ The de novo production of these terpenes; albicanyl acetate (12), cadlinaldehyde (13) and luteone (14) was subsequently proven by stable isotope labelling experiments. ${ }^{58}$
Antifeeding activity of $\mathbf{1 2}$ was detected, and it was found at high concentration in the mantle and mucus, indicating its role as a deterrent. ${ }^{51}$ A derivative of $\mathbf{1 2}, 1 \alpha, 2 \alpha$-diacetoxyalbicanyl acetate (15), was isolated from the egg masses of $C$. luteomarginata but not detected in the nudibranch itself. ${ }^{57}$ Whilst no feeding assays of $\mathbf{1 5}$ were conducted, its similarity to $\mathbf{1 2}$ indicated that it may act to protect the egg masses. ${ }^{58}$ Likewise de novo synthesis may be expected for 15, despite it not being detected to date in $C$. luteomarginata nudibranchs.

Initially, there was speculation that C. luteomarginata may be divided into subspecies based on geographic distribution, as a Californian population was originally thought not to contain any of the biosynthesised compounds 12-14. ${ }^{48,58}$ However, reexamination of this population utilising gas chromatography (GC) indicated that 12-14 were present but at low concentrations. ${ }^{48}$ It was found that broadly speaking, individuals of $C$. luteomarginata, from British Columbia, could be separated into two groups. The first group possessed 12-14 at high concentration, with other terpenoids that could be detected by GC at much lower concentration, whilst the second group contained 12-14 at concentrations below those of other GC detectable terpenoids. This variance both between and within geographic populations suggested that $C$. luteomarginata was able to downregulate biosynthesis if sufficient dietary terpenoids could be sequestered. ${ }^{48}$

A number of terpenoids were obtained from C. pellucida and C. laevis, including the furanosesquiterpene laevidiene (16) from the latter. The structures indicated a dietary origin from sponge prey, although only $C$. pellucida was observed feeding upon a sponge (Spongia agaricina). ${ }^{59}$

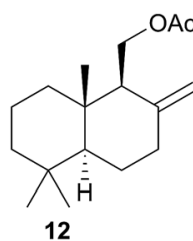<smiles>C=C1CC[C@H]2C(C)(C)C[C@@H](OC(C)=O)[C@@H](OC(C)=O)[C@@]2(C)[C@H]1COC(C)=O</smiles>

15

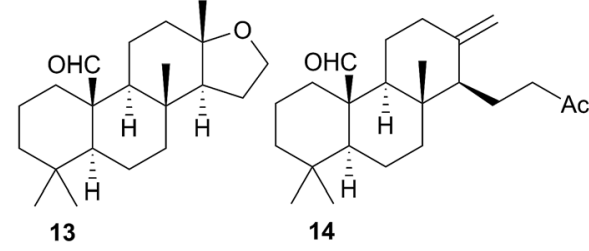

14

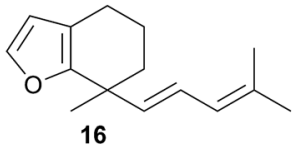

16
5.2.3 Chromodorididae. Chromodorididae is a large family with 17 accepted genera, 11 of which have been investigated chemically. The majority of natural product studies of nudibranchs have been conducted on this family, especially on the genus Chromodoris. There has been one reported study of a nudibranch from the genus Ardeadoris. An Australian collection of $A$. egretta yielded a new diterpene (17) but its bioactivity was not tested. ${ }^{60}$

Six furanoditerpenoids were obtained from Casella atromarginata (Doriprismatica atromarginata ${ }^{360}$ ) from Sri Lanka. ${ }^{61}$ Of these, two were known metabolites of an Australian Spongia sp. ${ }^{62}$ and two more were minor structural variants but two (18 
and 19) were novel metabolites, with a more highly oxidised Aring, containing a monoenolised $\alpha$-diketone function. ${ }^{61}$ It seems likely that $C$. atromarginata obtained these metabolites from its sponge prey. ${ }^{\mathbf{6 1}}$

Ceratosoma amoena (Ceratosoma amoenum ${ }^{361}$ ) from New Zealand was observed on the red alga Hymenea variolosa. ${ }^{63}$ The red algal metabolite allolaurinterol ${ }^{64}(\mathbf{2 0})$ was isolated from both the nudibranch and alga, a surprising result since, as noted by the researchers, the nudibranch dietary system is not capable of breaking down algal tissue. As an alternative explanation for this result, it was suggested that $C$. amoenum could be preying on an organism (or more likely its egg masses) that does sequester this compound from the alga. ${ }^{63}$

Nine new spongiane diterpenes were isolated from a South Australian nudibranch tentatively identified as Ceratosoma brevicaudatum $^{65}$ but later identified as Chromodoris epicura ${ }^{66}$ so perhaps it is unsurprising that these do not seem to be typical of the Cerastoma genus. A thiosesquiterpene (21) was isolated from the Australian nudibranch $C$. brevicaudatum but believed to be sequestered from a Dysidea sponge. ${ }^{67}$ The ecological role of $\mathbf{2 1}$ has not been studied, but it represents a relatively rare example of a sulphur containing sesquiterpene from the marine environment. ${ }^{67}$ Four "typical" sponge furanosesquiterpenoids, pallescensin- $\mathrm{B},{ }^{68}$ (-)-furodysinin, ${ }^{69}$ dehydroherbadysidolide $^{70}$ and herbadysidolide ${ }^{71}$ were isolated from two species of Ceratosoma; C. trilobatum and C. gracillimum. ${ }^{66}$ As previously reported, ${ }^{72}(-)$-furodysinin, exhibited feeding deterrent and ichthyotoxic properties, and additionally, concentration of the compound in the dorsal horn glands of the animals, supports the proposed defensive role of the dorsal horns. ${ }^{66}$
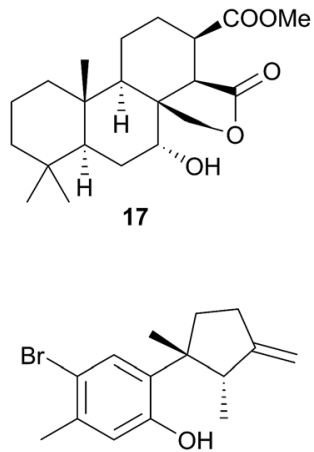

20

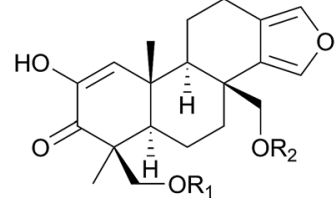

$$
18 R_{1}=R_{2}=A c
$$$$
19 R_{1}=R_{2}=H
$$
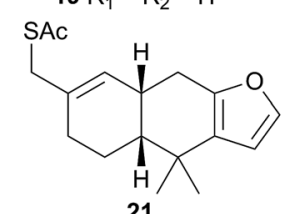

Chromodoris is the most examined of all nudibranch genera, with many reported studies,,$^{\mathbf{8}, 39,73-106}$ although many of the species in these studies originally classified as Chromodoris have been reclassified as Doriprismatica, ${ }^{75}$ Feli- $^{-}$ mida ${ }^{73,76,79,80,85,87,90,93} \quad$ Glossodoris ${ }^{79,101} \quad$ Goniobranchus $^{39,86,88,89,95,98,102-104}$ or Hypselodoris. ${ }^{74,106}$ Chromodoris species feed exclusively on sponges and sequester a large number of terpenoid metabolites from their prey including sesquiterpenes, ${ }^{73,74,78,82,106}$ norditerpenes, ${ }^{\mathbf{8 0}}$ diter-

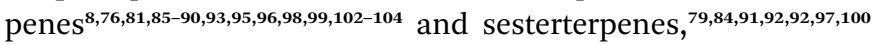
although macrolides ${ }^{77,82,83,105}$ and bromophenols ${ }^{78}$ have also been reported. In some instances, metabolites have been simultaneously isolated from sponge and nudibranch, highlighting that they are of dietary origin. For example, the macrolides laulimalide $(22)^{107,108}$ and isolaulimalide $(23)^{109}$ were isolated from sponges of the Hyattella genus and from their nudibranch predator C. lochi $^{83}$

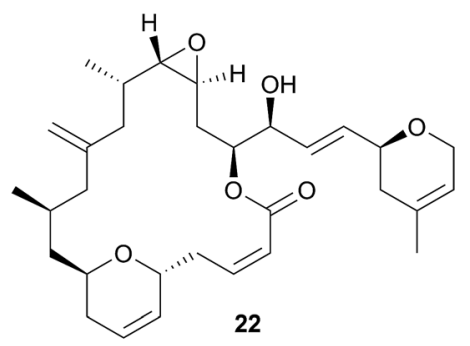<smiles></smiles>

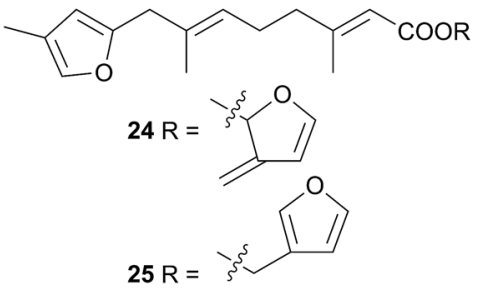

Latrunculin A, a sponge metabolite originally obtained from Latrunculia magnifica ${ }^{\mathbf{1 1 0}}$ has been isolated from several Chromodoris species, ${ }^{77,82,94,105}$ and has been shown to be selectively stored in the mantle rim for protective purposes. ${ }^{\mathbf{1 0 5}}$ In other cases, structural analogues of nudibranch metabolites have been detected in or isolated from, the sponge prey, indicating the likelihood of secondary modification of sponge metabolites. For example, the sesquiterpene marislin (24), obtained from C. marislae (Felimida marislae ${ }^{374}$ ), is related to the spongian metabolite pleraplysillin-2 (25), from Pleraplysilla spinifera, by a $[3,3]$ sigmatropic rearrangement. ${ }^{73}$ Similarly, deoxymanoalide (26) and deoxysecomanoalide (27), isolated from $C$. willani, are modified from manoalide (28) and secomanoalide (29) respectively by loss of an hydroxyl group. Both 28 and 29 were identified in the sponge prey of $C$. willani. ${ }^{100}$ Some chlorinated homoditerpenes including hamiltonin A (30) $)^{94}$ were isolated from $C$. hamiltoni along with latrunculins and a sesterterpene but in this case, the origin of the chlorinated compounds was not clear. ${ }^{94}$ Where they have been assessed, virtually all of the metabolites obtained from Chromodoris species have displayed a moderate degree of bioactivity, indicating their role in limiting predation. Despite evidence suggesting secondary modification occurs, there have been no reports of de novo synthesis within Chromodoris to date. 


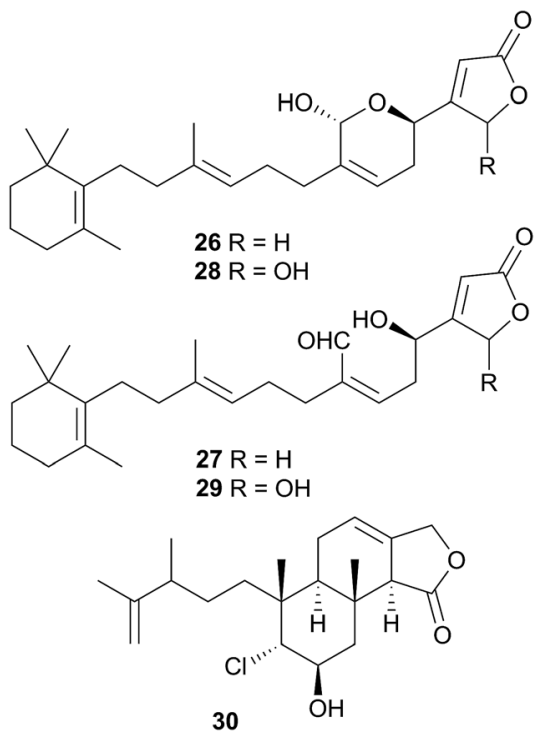

A species, denoted by researchers as Felimida grahami (Felimare grahami, ${ }^{383}$ ) sequestered rearranged terpenoids from its sponge prey Darwinella cf. oxeata. ${ }^{\mathbf{1 1 1}}$ These included oxeatamide I (31), one of three new oxeatamides $\mathrm{H}-\mathrm{J}^{111}$ found in the sponge to add to those already known ${ }^{112}$ and membranolide, ${ }^{113}$ previously isolated from the sponge Dendrilla membranosa ${ }^{\mathbf{1 1 3}}$ and from nudibranchs Goniobranchus reticulatus ${ }^{\mathbf{1 0 2}}$ and G. splendidus. ${ }^{\mathbf{1 1 4}}$

As for Chromodoris, many of the species originally reported as Glossodoris have been reclassified, in this case as Ardeadoris, ${ }^{115}$ Chromodoris, ${ }^{116}$ Doriprismatica, ${ }^{39,117-120}$ Felimare $^{121}$ and Felimida. ${ }^{\mathbf{1 2 0}}$ Although latrunculin B has been isolated from $G$. tricolor, this is now classified as Felimare ${ }^{387}$ and all other metabolites isolated from this genus are terpenoids and predominantly sponge derived. ${ }^{\mathbf{1 1 5 , 1 1 7 - 1 2 6}}$ Spongian diterpenes have been obtained, ${ }^{\mathbf{1 1 7}, \mathbf{1 1 9}}$ but most of the metabolites isolated are based on the sponge-derived scalarane sesterterpene, scalaradial (32), ${ }^{\mathbf{1 1 5}, \mathbf{1 1 9}, \mathbf{1 2 1 - 1 2 5}}$ including norscalaranes ${ }^{\mathbf{1 1 9}}$ and homoscalaranes. ${ }^{120}$ A number of the scalarane metabolites obtained were 12-keto derivatives such as $\mathbf{3 3}{ }^{\mathbf{1 2 4}}$ and since in every case, they were only obtained from the nudibranch and not from the sponge prey, it is considered highly likely that biotransformation of the sponge scalarane occurs in the nudibranch, ${ }^{\mathbf{1 2 4}}$ most likely through enzymatic oxidation. ${ }^{115}$<smiles>C[C@H](C(=O)O)c1c([C@@]2(C)CCCC(C)(C)C2)ccc2c1CNC2=O</smiles>

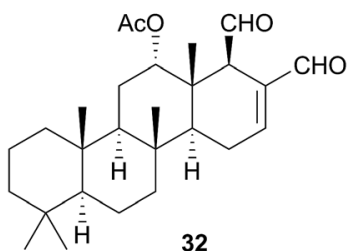

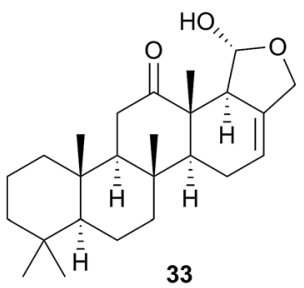

As noted above, taxonomic revisions have led many species that were formerly Chromodoris to be reclassified as Goniobranchus. From species originally reported as Goniobranchus, a range of diterpenes and norditerpenes have been obtained and all studies thus far have been of Australian specimens. ${ }^{\mathbf{6 0 , 1 1 4 , 1 2 6 - 1 2 8}}$ In most cases, known sponge metabolites were co-isolated with the novel metabolites reported and compounds were sometimes isolated from both the nudibranch and its prey sponge. 12-Acetoxy dendrillolide (34) for example was obtained from both $G$. albonares and the crimson sponge on which it was feeding. ${ }^{126}$ The activity of isolated metabolites has been quite varied. For example, of the six new oxygenated norditerpene/ bisnorditerpene metabolites isolated from G. splendidus, gracilins M-Q displayed significant potency against the HeLa S3 cell line, aplytandiene-3 was essentially inactive and the rearranged diterpene daphnelactone (35) reported from $G$. daphne in the same study was not tested. ${ }^{114}$ Another study of G. splendidus yielded some oxygenated diterpenes but these were not tested for activity. ${ }^{60}$ G. verrieri yielded seven new norditerpenes and diterpenes, all with highly rearranged carbon skeletons, such as the cyclopropyl-containing verrielactone (36) and a biosynthetic pathway to these metabolites from spongialactone was proposed. ${ }^{\mathbf{1 2 7}}$ All six new spongian-16-one diterpenes found localised in the mantle of G. collingwoodi (an example being 37) were inactive to a range of HTCLs but preliminary testing of whole body extracts indicated some antifeedant activity against Palaemon serenus (rock pool shrimp). ${ }^{\mathbf{1 2 8}}$
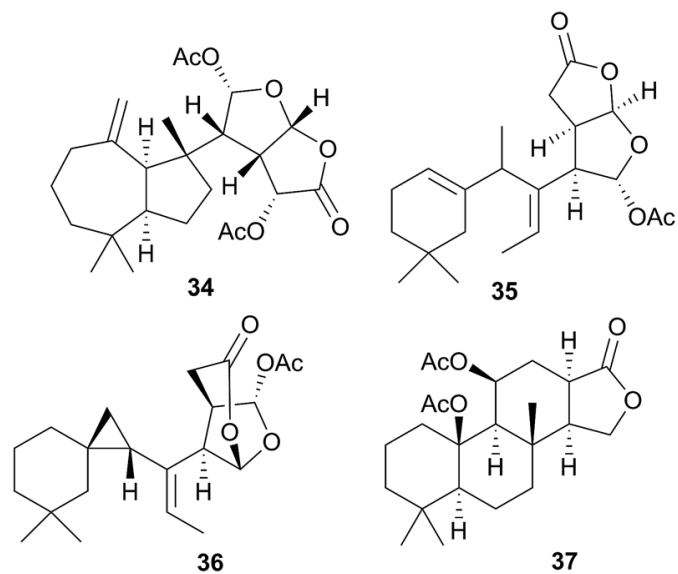

The majority of species originally reported as Hypselodoris have been reclassified as Felimare $e^{\mathbf{8 , 7 2 , 1 2 9 - 1 3 8}}$ or in one case, Risbecia $^{\mathbf{1 0 6}}$ but the genus sequesters terpenes, ${ }^{\mathbf{8}, 72,98,106,129-139}$

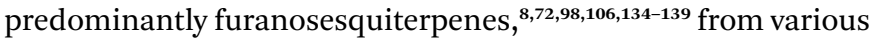
species of sponge, of which longifolin ${ }^{138}$ (38) is typical. Longifolin (38) is sequestered from Dysidea sponges $^{\mathbf{1 0 6 , 1 3 0 , 1 3 6 , 1 3 7}}$ and it and other antifeedant compounds are present in the MDFs of many Hypselodoris species ${ }^{\mathbf{8 , 7 2 , 1 3 1}}$ and released when the nudibranch is molested. There is one reported isolation of a sesterterpene from this genus. ${ }^{\mathbf{1 3 3}} \mathrm{H}$. orsini( $i$ ) (Felimare orsinii) ${ }^{\mathbf{3 9 7}}$ feeds on the sponge Cacospongia mollior but contains different metabolites to its prey. It is thought that the nudibranch converts the sponge sesterterpenoid scalaradial, into deoxoscalarin, then, a second chemical transformation produces the 
sesterterpenoid, 6-keto-deoxoscalarin which is also stored in MDFs. ${ }^{133}$

A number of oxy-polybrominated diphenyl ethers (O-PBDEs) have been isolated from the nudibranchs Miamira magnifica and M. miamirana from Australia, of which 39 from M. magnifica is a typical example. ${ }^{\mathbf{1 4 0}}$ These compounds are sequestered from sponges and although such compounds have been isolated from nudibranchs previously, ${ }^{78,141}$ they were found in the gut tissue, whereas in the Miamira specimens, they were additionally located in the mantle and dorsal horn tissues, so likely play a role in chemical defence. ${ }^{\mathbf{1 4 0}}$

As part of a study of Chromodorid species, ${ }^{8}$ Risbecia tryoni (Hypselodoris tryoni $^{\mathbf{4 0 2}}$ ) yielded the sponge metabolite (-)-furodysinin $^{142}$ and the lipid and fatty acid content has also been examined. ${ }^{39}$ There has only been one chemical study of the Tyrinna genus. Tyrinnal (40), a seco-11,12-spongiane was obtained from the mantle and MDFs of Patagonian Tyrinna nobilis (Tyrinna delicata $^{\mathbf{4 0 3}}$ ) along with three known furanosesquiterpenes. ${ }^{\mathbf{1 4 3}}$

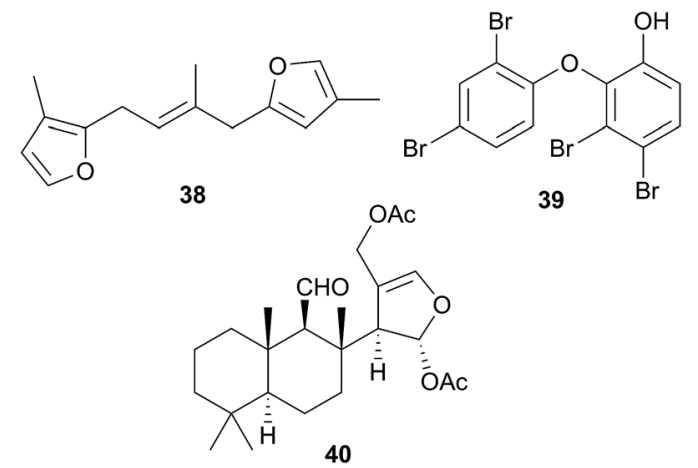

5.2.4 Discodorididae. The Discodorididae are a large family of nudibranchs consisting of 30 genera. Only eight of these have been chemically examined (and some of these examples have been reclassified to other genera within the family, ${ }^{\mathbf{1 4 4 , 1 4 5}}$ or in one case, to a genus in the Dorididae family ${ }^{146}$ ) but they have yielded metabolites from a range of classes.

A number of diterpenoid diacylglycerols have been isolated from this family, including the anisodorins 1-5, which were obtained from the skin of the Patagonian species Anisodoris fontainei (Doris fontainii ${ }^{\mathbf{4 0 5}}$ ) along with two further analogues. ${ }^{\mathbf{1 4 6}}$ These last two compounds were previously reported from the same species ${ }^{\mathbf{1 4 7}}$ (but erroneously classified as Archidoirs carvi ${ }^{\mathbf{1 4 6}}$ ) and are diastereoisomers of two further diacylglycerols obtained from Archidoris tuberculata (Doris pseudoargus ${ }^{\mathbf{4 0 9}}$ ), collected along the northern Spanish coast. ${ }^{147}$ Surprisingly, the isomers from each source display opposite absolute stereochemistry in their terpenoid moiety. The absolute stereochemistry of anisodorin 5, 41 was established through synthesis of its enantiomer ${ }^{\mathbf{1 4 8}}$ and $\mathbf{4 1}$ itself has also been synthesised. ${ }^{\mathbf{1 4 9}}$ Anisodoris nobilis (Peltodoris nobilis ${ }^{\mathbf{4 0 4}}$ ) was the source of doridosine $^{\mathbf{1 4 4}}$ (1-methylguanosine), a hypotensive compound ${ }^{\mathbf{1 5 0}}$ that was also obtained from the Australian sponge Tedania digitata. ${ }^{151}$ A degraded sesquiterpenoid was obtained from $A$. nobilis as the odoriferous principle. ${ }^{152}$

Asteronotus cespitosus specimens collected from Australia and the Philippines contained a range of halogenated metabolites and two sesquiterpenes. ${ }^{\mathbf{1 4 1}}$ One of these was a novel chlorinated pyrrolidone (42), while all of the other metabolites had been previously isolated from Dysidea herbacea. ${ }^{\mathbf{1 4 1}}$ Pyrrolidone (42) has a similar structure to dysideapyrrolidone, ${ }^{\mathbf{1 5 3}}$ a sponge metabolite.

Isoguanosine, a compound previously isolated as a constituent of the croton bean ${ }^{154}$ was obtained from Diaulula sandiegensis. ${ }^{155} \mathrm{~A}$ Californian population of $D$. sandiegensis contained a series of nine chlorinated acetylenes, of which 43 is a typical example. ${ }^{156}$ Over twenty years later, six of the metabolites were isolated from the sponge Haliclona lunisimilis which was collected in the same area as the nudibranchs were originally. ${ }^{157}$ The two major metabolites found in D. sandiegensis (both ketones) were not present in the sponge, although the corresponding alcohols were, suggesting modification of the alcohols by the nudibranch. ${ }^{\mathbf{1 5 7}}$ Steroidal metabolites, diaulusterols A (44) and B (45), have been isolated from a British Columbian collection of $D$. sandiegensis. ${ }^{158}$ Stable isotope experiments indicated that the polyketide chain of $\mathbf{4 4}$ was biosynthesised by the nudibranch itself, whereas there was no evidence of uptake in the steroidal nucleus. ${ }^{159}$ Radiolabelled incorporation also failed to prove biosynthesis of the steroid nucleus. ${ }^{159}$ This suggested that as for Aldisa cooperi, ${ }^{46}$ a precursor steroid was sequestered and subsequently modified, although a prey species has yet to be identified..$^{\mathbf{1 5 8 , 1 5 9}}$
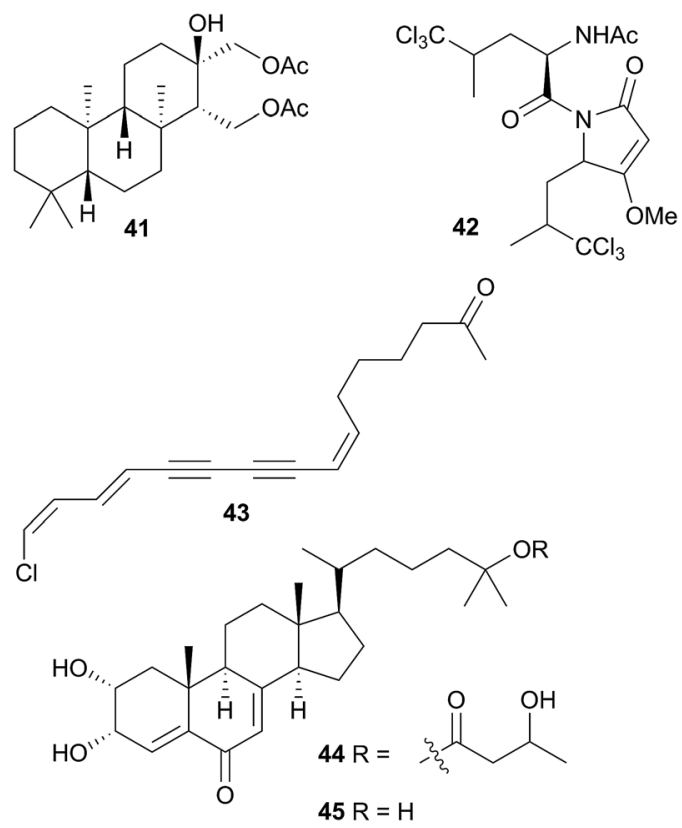

Five species of the Halgerda genus collected from various locations around Australia and from Okinawa, Japan were examined. Of these, $H$. aurantiomaculata yielded the new tryptophan derivative halgerdamine (46), in addition to four known nitrogenous compounds, while $H$. gunnessi yielded mixtures of acylated tetrasaccharides. ${ }^{\mathbf{1 4 5}}$ No secondary metabolites were detected in H. theobroma, H. rubicunda (Sclerodoris rubicunda ${ }^{\mathbf{4 0 6}}$ ) or $H$. willeyi, leading the authors to suggest that these nudibranchs may have evolved to exploit a wider range of food including nontoxic sponges rather than sequestering or synthesising protective compounds. ${ }^{\mathbf{1 4 5}}$ Organic extracts of an Indian specimen 
of $H$. stricklandi displayed modest activity to Staphylococcus aureus and no activity against a range of other bacterial and fungal species. ${ }^{\mathbf{1 6 0}}$

Jorunna funebris is another nudibranch to yield non terpenoid natural products. Studies of the nudibranch and its prey, sponges of the genus Xestospongia, indicate that $J$. funebris sequesters a range of isoquinolinequinones ${ }^{160-163}$ and bistetrahydroisoquinolines ${ }^{\mathbf{1 6 2 , 1 6 4 , 1 6 5}}$ from the sponge. Some of the isoquinolinequinones have been synthesised ${ }^{166}$ and the metabolites possess a range of biological activities, including antibacterial activity, ${ }^{161,164}$ cytotoxicity to HTCLs, ${ }^{162,164,165}$ and NF- - B inhibitory activity. ${ }^{162}$ Jorumycin (47) was not found in the sponge but was isolated from the mucus and mantle of an Indian collection of $J$. funebris. It exhibited very potent cytotoxicity towards various tumour types but was only available in small quantities due to instability of the carbinolamine moiety. ${ }^{\mathbf{1 6 4}}$ Pretreatment of the nudibranch tissues with potassium cyanide, resulted in isolation of jorunnamycins A-C (C pictured as 48), more stable compounds which retained high cytotoxicity to human tumour cell lines. ${ }^{165}$ Zalypsis ${ }^{\circledR}$, a synthetic compound derived from jorumycin, ${ }^{\mathbf{1 6 7}}$ is currently in Phase II clinical trials for treatment of endometrial and cervical cancer. ${ }^{168}$
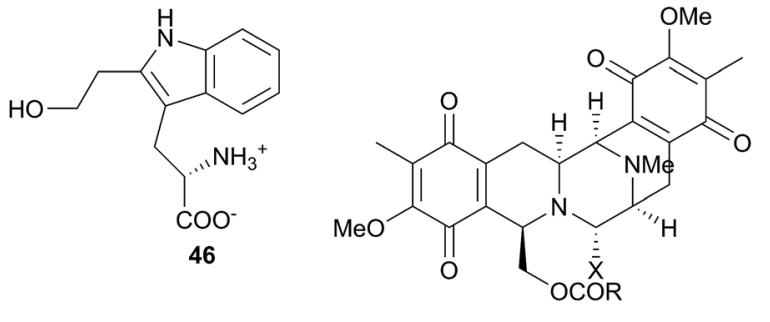

$47 \mathrm{R}=\mathrm{Me}, \mathrm{X}=\mathrm{OH}$

$48 \mathrm{R}=\mathrm{Et}, \mathrm{X}=\mathrm{CN}$

Several studies have chemically linked the nudibranch $\mathrm{Pel}$ todoris atromaculata to its prey sponges Petrosia ficiformis ${ }^{\mathbf{1 6 9 , 1 7 0}}$ and Haliclona fulva, ${ }^{171}$ indicating sequestration of sponge metabolites by $P$. atromaculata, including sterols, ${ }^{169}$ the polyacetylene alcohols, petroformynes ${ }^{\mathbf{1 7 0}}$ and fulvinol-related polyacetylenes. ${ }^{\mathbf{1 7 0}}$ One of these last compounds was moderately cytotoxic to the SKMEL-28 melanoma cell line. ${ }^{171}$ The lipid and fatty acid content of the related Platydoris sp. were examined as part of a study of eight nudibranch species. ${ }^{39}$

The sesquiterpene glyceride esters, tanyolides A and B were isolated from Sclerodoris tanya from Southern California. Located mainly in the mantle of the nudibranch, both deterred feeding by fish predators and were also synthesised. ${ }^{172}$ Feeding experiments utilising $\left[2-{ }^{13} \mathrm{C}\right]$ mevalonolactone indicated that Sclerodoris tanya is capable of de novo biosynthesis of the terpenoid fragment of tanyolide B. ${ }^{173}$

5.2.5 Dorididae. The Dorididae family consists of six genera. All Dorididae species originally classified as Archidoris and Austrodoris have been reclassified as Doris ${ }^{\mathbf{4 0 5 , 4 0 7 - 4 1 0}}$ so technically only this genus has been chemically examined, but there have been quite a number of reports published under the original genera names. ${ }^{147,152,173-180}$ Given the reclassification, it is unsurprising that terpenoid glyceryl esters have been reported from all three genera and seem to serve as "chemical markers" of the family. ${ }^{174}$
Species originally classified as Archidoris have yielded sesquiterpenoic ${ }^{152,175,176}$ and diterpenoic acid $^{\mathbf{1 4 7 , 1 5 2 , 1 7 6 - 1 7 8 , 1 8 0}}$ glycerides, in addition to a glyceryl ether. ${ }^{152}$ Archidorin (49) ${ }^{178}$ is a typical example. Many of these compounds were isolated from the skin or mantle of the nudibranchs and were icthyotoxic, ${ }^{147,152,177,178,180}$ and in one study, were additionally shown to be passed from the adults into the egg masses for protection. ${ }^{\mathbf{1 8 0}}$ Diastereoisomeric variants of some of the diterpenoic acid glycerides were obtained from geographically distinct populations of Archidoris nudibranchs ${ }^{\mathbf{1 4 7}}$ and some of these compounds have been synthesised. ${ }^{\mathbf{1 7 4 , 1 7 9}}$ Evidence from biosynthetic feeding experiments indicate that the nudibranchs likely synthesise these molecules de novo. ${ }^{\mathbf{1 7 3}}$

The Antarctic nudibranch Austrodoris kerguelenensis (Doris kerguelenensis ${ }^{\mathbf{4 1 0}}$ ) has yielded a number of diterpene glycerides with a variety of skeletons, even within one population, ${ }^{\mathbf{1 8 1}}$ including ent-labdane, ${ }^{\mathbf{1 8 2 , 1 8 3}}$ labdane, ${ }^{\mathbf{1 8 4}}$ halimane, ${ }^{\mathbf{1 8 4 , 1 8 5}}$ clerodane $^{184,186,187}$ and isocopalane ${ }^{188}$ frameworks. ${ }^{186,189}$ Some norsesquiterpenes ${ }^{\mathbf{1 9 0}}$ have also been isolated from this well-studied species. Of the compounds isolated, some of the diterpene diacylglycerides had feeding deterrent activity against the predatory seastar Odontaster validus, ${ }^{191}$ some of the clerodane (palmadorins $\mathrm{A}$ and $\mathrm{B}$ ) and labdane (palmadorins $\mathrm{M}-\mathrm{O}$ ) diterpenes were growth inhibitory to human erythroleukamia (HEL) cells and palmadorin M (50) was shown to be apoptotic to these cells. ${ }^{184}$ Not surprisingly, as for Archidoris, it is thought likely that the above compounds are biosynthesised de novo by the nudibranch. ${ }^{191,192}$

The verrucosins are also diterpenoid acid glycerides obtained from Doris verrucosa ${ }^{\mathbf{1 9 3 , 1 9 4}}$ and in addition to icthyotoxicity, verrucosins A and B (51 and 52) were shown to be potent activators of protein kinase $\mathrm{C}$ and to promote tentacle regeneration in the freshwater hydrozoan Hydra vulgaris. ${ }^{195}$ Biosynthetic feeding experiments with ${ }^{14} \mathrm{C}$ labelled mevalonic acid and glycerol resulted in poor incorporation into the verrucosins so de novo biosynthesis was not proven but good incorporation into sterols did establish that the mevalonate pathway was operative in the nudibranch. ${ }^{196}$ A xylosyl thioether, 9-[5'-deoxy$5^{\prime}$ (methylthio)- $\beta$-D-xylofuranosyl $]$ adenine was also obtained from $D$. verrucos$a^{197-199}$ and biosynthetic studies indicated that it
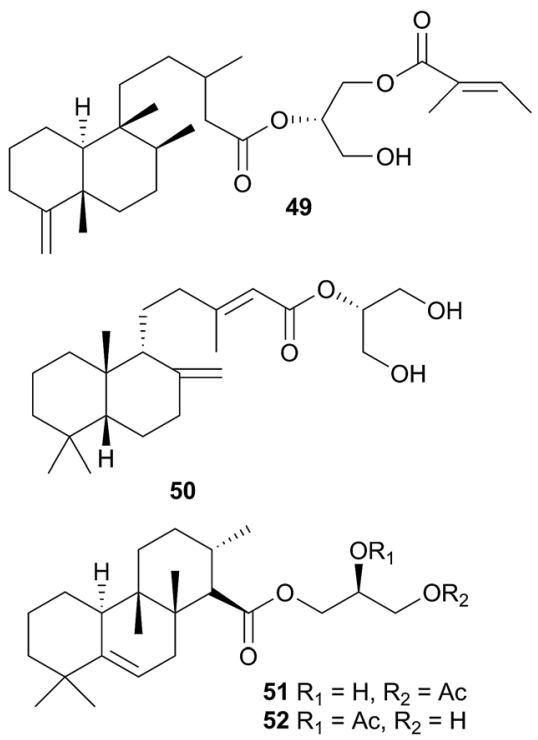
arises in $D$. verrucosa from isomerisation of endogenous $5^{\prime}$ deoxy-5'-methylthioadenosine (MTA). ${ }^{200}$

\subsection{Onchidoridoidea}

The Onchidoridoidea consists of five families but only representatives of the Onchidorididae and the Goniodorididiae have been examined for natural products.

5.3.1 Onchidorididae. The family Onchidorididae comprises five genera and has been little studied chemically. Only one species from each of two genera (Acanthodoris and Adalaria) has been examined. Acanthodoris nanaimoensis from British Columbia yielded three sesquiterpenoid aldehydes with novel skeletons, nanaimoal, ${ }^{201}$ acanthodoral $^{202}$ and isoacanthodorane. ${ }^{202}$ Biosynthetic studies involving injecting the animals with $\left[1,2{ }^{13} \mathrm{C}_{2}\right]$ acetate, indicated that the compounds were biosynthesised de novo by the nudibranchs and a biosynthetic scheme was proposed. ${ }^{203}$ A degraded triterpenoid, lovenone (53) was isolated from skin extracts of a Norwegian collection of Adalaria loveni and displayed modest cytotoxicity to two HTCLs. A dietary origin was suspected, given the lack of any such metabolites in a closely related species. ${ }^{204}$

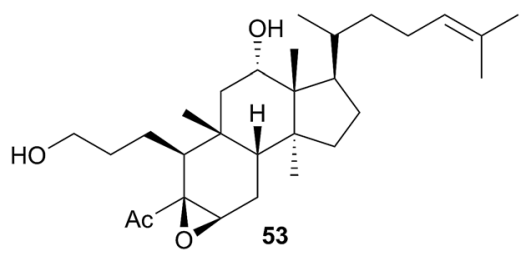

5.3.2 Goniodorididiae. The Goniodorididiae family comprises eight genera of which only one, Hopkinsia, has been examined for natural products. Hopkinsia rosacea (Okenia rosa$c e a^{411}$ ) yielded a seemingly unique apocarotenoid, hopkinsiaxanthin which is similar to the carotenoid fucoxanthin found in marine plants. ${ }^{205,206}$ The alkaloid 2,5,6-tribromo- $N$-methylgramine was obtained from the nudibranch Okenia zoobotryon and from its bryozoan prey, Zoobotryon verticillatum ${ }^{\mathbf{1 3 7}}$ (Amathia verticillata ${ }^{\mathbf{2 0 7}}$ ).

\subsection{Phyllidioidea}

The Phyllidiodea superfamily comprises three families (Dendrodoridae, Mandeliidae and Phyllidiidae) and is very well studied, although no representatives of the Mandeliidae have been studied to date. All metabolites isolated thus far from this superfamily have been terpenes.

5.4.1 Dendrodoridae. Two of the three genera comprising the Dendrodoridae family (Dendrodoris and Doriopsilla) have been chemically examined. The discovery of de novo synthesis of the drimane sesquiterpene polygodial (54) in Dendrodoris limbata was the first proven example of biosynthesis in a nudibranch. ${ }^{208}$ The antifeeding properties of 54, in conjunction with its localisation solely within the mantle, indicated its defensive role. ${ }^{208}$ Surprisingly, $\mathbf{5 4}$ was found to be toxic to D. limbata if injected directly into the hepatopancreas, ${ }^{\mathbf{2 0 9 , 2 1 0}}$ presumably due to its reactivity with free amino groups. ${ }^{\mathbf{2 0 8 , 2 1 0}}$ It was speculated that a protected form of $\mathbf{5 4}$ must be produced in order to facilitate transport throughout the nudibranch. Olepupuane
(55) was also found in D. limbata and was converted to 54 in the presence of aqueous acid, suggesting that $\mathbf{5 5}$ was the protected form. ${ }^{210}$ A mixture of three fatty acid esterified sesquiterpenoids isolated from $D$. limbata may offer an alternative storage or handling method of the toxic $\mathbf{5 4}$ for the nudibranch. ${ }^{211}$

Biosynthesis of $\mathbf{5 4}$ and related compounds has been proven in Dendrodoris grandiflora through radiolabelling experiments. ${ }^{\mathbf{2 1 2 , 2 1 3}}$ Whilst 54 was extracted from the mantle, the fatty acid esterified sesquiterpenoids were found in the digestive glands along with a series of known spongian terpenes. ${ }^{212}$ Other studies have reported drimane sesquiterpenes from Dendrodoris carbunculosa, ${ }^{214}$ D. nigra, D. tuberculosa and D. krebsii. ${ }^{215,216}$ The anatomical distribution and role that such terpenes may play has been investigated in Mediterranean Dendrodoris nudibranchs. ${ }^{217}$ The presence of sequestered sponge metabolites might indicate a dual defence for Dendrodoris species but they were completely absent from the mantle, where one would expect to find defence allomones. Unlike Cadlina luteomarginata, in which it appears de novo synthesis is downregulated when sequestered metabolites are available, ${ }^{48} \mathrm{D}$. grandiflora still utilises its own natural products for defence.

Drimane biosynthesis has also been reported in Dendrodoris arborescens, in the form of 56, following radiolabelling studies and another drimane, $6 \beta$-acetoxypolygodial (57), was also isolated from the mantle of $D$. arborescens. ${ }^{213}$ Feeding experiments with ${ }^{14} \mathrm{C}$ - and ${ }^{13} \mathrm{C}$-labelled glucose on $D$. limbata and D. grandiflora indicated that glucose was incorporated into the terpenoid portion of drimanes via the standard mevalonate pathway. ${ }^{218} \mathrm{~A}$ more recent study identified the presence of symbiotic bacteria in the outer tissues of D. nigra and it was suggested that they could be implicated in defence from predators. ${ }^{219}$

In a New Zealand study, the sesquiterpene cinnamolide (58) was detected in all specimens of $D$. denisoni examined, regardless of geographic location or age, potentially indicating that it was biosynthesised by the nudibranch. ${ }^{61}$ Cinnamolide (58) has previously only been obtained from terrestrial plants. ${ }^{220}$

Studies of species of the related Doriopsilla genus including $D$. albopunctata $^{215,216}$ D. janaina, ${ }^{215}$ D. pelseneeri ${ }^{221}$ and D. areolata $^{\mathbf{2 1 1 , 2 2 2 - 2 2 4}}$ indicated that they also contained drimane sesquiterpenoids, as well as enantiomerically related sesquiterpenoids of the ent-pallescensin A skeleton. ${ }^{221-224}$ Biosynthetic investigations of $D$. areolata $^{222,223}$ and $D$. pelseneeri ${ }^{225}$ indicated that they produce both drimane sesquiterpenoids and sesquiterpenoids with the ent-pallescensin A skeleton de novo and their presence in the mantle of $D$. areolata indicated that they too were involved in the chemical defence of the nudibranch. ${ }^{222,223}$
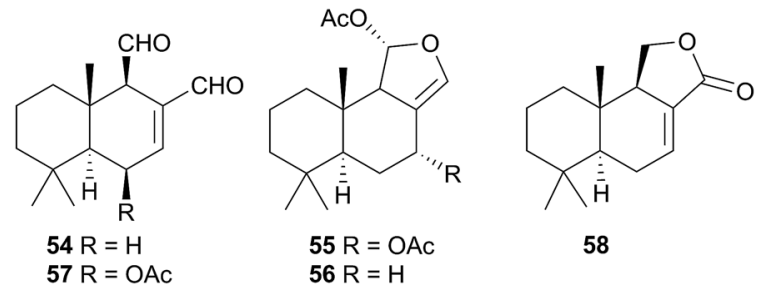

$56 \mathrm{R}=\mathrm{H}$ 
5.4.2 Phyllidiidae. Representatives of four of the five genera comprising the Phyllidiidae family (Phyllidia, Phyllidiella, Phyllidiopsis and Reticulidia) have been chemically studied. Despite de novo synthesis being well documented among the superfamily Phyllidioidea, sequestering of metabolites still occurs, especially within the genus Phyllidia. A number of highly bioactive metabolites have been reported from this genus following the isolation of 9-isocyanopupukeanane (59) from $P$. varicosa. ${ }^{226}$ Evaluating the prey of the nudibranch revealed that $\mathbf{5 9}$ was sequestered from a sponge of the Hymeniacidon genus. The mucus secreted by $P$. varicosa is concentrated with respect to $\mathbf{5 9}$ and is known to be toxic to fish and crustaceans. ${ }^{226}$ 2-Isocyanopupukeanane was later isolated from the nudibranch and again shown to be sequestered from a Hymeniacidon sp. ${ }^{227}$ epi-9-Isocyanopupukeanane (60) has been reported to co-occur with 59 in $P$. bourgini ${ }^{228}$ (Phyllidiella rosans ${ }^{412}$ ). Thiocyano derivatives of these metabolites, 61-62, have also been isolated from $P$. varicosa and its sponge prey Axinyssa aculeata and were noted to be moderately antibacterial. ${ }^{229}$ Subsequent studies have found a number of related nitrogenous mono-, bi- and tricyclic sesquiterpenes from Phyllidia sp. ${ }^{230}$ P. varicosa, ${ }^{231,232} P$. ocellata ${ }^{232-234}$ P. coelestis, ${ }^{235}$ and P. pustulosa. ${ }^{231,232,236,237}$ Phyllidia pustulosa has been reclassified as Phyllidiella pustulos $\mathbf{4}^{\mathbf{4 1 3}}$ so unsurprisingly, several studies of the animal reported as Phyllidiella pustulosa also yielded nitrogenous sesquiterpenes, ${ }^{238-242}$ although one additionally yielded nitrogenous diterpenes, ${ }^{240}$ which had also been isolated previously from a sponge. ${ }^{240}$ Phyllidiopsis krempfi also yielded nitrogenous sesquiterpenes and a sesquiterpene peroxide. ${ }^{232}$ Potent antifouling activity has been reported for some of these compounds against barnacle larvae $e^{232,237,243,244}$ and several also possess antimalarial activity against Plasmodium falciparum..$^{\mathbf{2 3 4 2 3 9}}$ The lipid content of Phyllidia coelestis ${ }^{\mathbf{2 4 5}}$ and the fatty acid content of $P$. varicos ${ }^{246}$ and Phyllidiella pustulosa ${ }^{246}$ have also been examined.

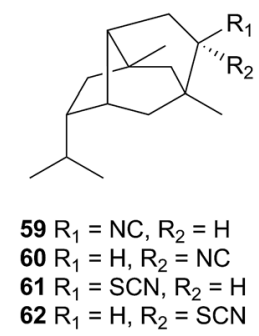

A series of cytotoxic, antifouling sesquiterpenes (63-66) was isolated from Reticulidia fungia ${ }^{247}$ which possess an unique carbonimidic dichloride functionality. Two of the metabolites, reticulidins $A(63)$ and $B(64)$ are novel to the nudibranch and were moderately cytotoxic to two HTCLs, ${ }^{247}$ whilst the other two metabolites (65 and 66) had previously been isolated from the sponge Pseudaxinyssa pitys. ${ }^{\mathbf{2 4 8 , 2 4 9}}$ The structural similarities to 65, and the rarity of the carbonimidic dichloride functionality, suggests that 63 and 64 are also likely sequestered from an, as yet unidentified, Pseudaxinyssa sponge.<smiles>CC1(C)[C@H](Cl)[C@H](O)C[C@]2(C)C=C(/C=C/N=C(Cl)Cl)CC[C@@H]12</smiles><smiles>CC1(C)[C@H](Cl)[C@H](O)C[C@]2(C)CC(/C=C/N=C(Cl)Cl)=CC[C@H]12</smiles><smiles>CC(C)=CCC[C@]1(C)C/C(=C(/Cl)CN=C(Cl)Cl)C[C@H](O)[C@@H]1Cl</smiles>

\subsection{Polyceroidea}

Although only three of the five families in the Polyceroidea have been chemically examined, the superfamily represents a remarkably diverse range of dorids that have attracted considerable attention from researchers.

5.5.1 Aegiridae. Two genera (Aegires and Notodoris) comprise the Aegiridae family but only Notodoris species have been examined to date. Nudibranchs of this genus, are specialist feeders, known to prey predominantly on sponges of the genus Leucetta, ${ }^{250}$ and are bright yellow, matching the colour of their sponge prey. The colouration in the sponges is caused by a range of at least 13 imidazole alkaloids ${ }^{250-253}$ of which naamidine A (67) is a representative metabolite. Many of these compounds have also been isolated from Notodoris citrina ${ }^{250}$ and $N$. gardineri ${ }^{251}$ after feeding on Leucetta. In addition, three metabolites only present in the nudibranch were obtained; dorimidazole A (68), ${ }^{251}$ preclathridine A (69) and clathridine B<smiles>COc1ccc(Cc2nc(NC3=NC(=O)C(C)C3=O)n(C)c2Cc2ccc(O)cc2)cc1</smiles><smiles>C[18O]c1ccc2c(c1)OCO2</smiles> 
(70) ${ }^{252}$ Biosynthesis of these compounds is unlikely, due to structural similarities with other sponge metabolites. ${ }^{251}$ Some of these compounds have been found to be antiparasitic ${ }^{251}$ and are presumably sequestered by Notodoris for this activity. ${ }^{251}$

5.5.2 Hexabranchidae. The family Hexabranchidae contains one genus, Hexabranchus, which has predominantly, but not exclusively, yielded macrolides. Hawaiian specimens of the bright red "Spanish dancer" nudibranch, Hexabranchus sanguineus, have yielded a number of bioactive macrocyclic lactones (macrolides). Ulapualide A (71) and B (72) were isolated from egg masses, in high concentration, and were both cytotoxic (against leukaemia) and antifungal in nature. ${ }^{254}$ They were also detected in the nudibranch itself, although at much lower concentrations. ${ }^{254}$ Three additional related macrolides, ulapualides C-E were isolated from egg masses of $H$. sanguineus, also obtained from Hawaii. Only ulapualide $\mathrm{C}$ was isolated in sufficient quantity for compounds), is derived from potent depolymerisation of the actin cytoskeleton within cells. ${ }^{262}$

Most of these macrolides are strongly suspected of being of dietary origin as they were found in both the mantle and digestive tracts of the nudibranch. ${ }^{258}$ Furthermore, halichondramide $^{261}$ and derivatives have been isolated from Halichondria sponges and these sponges are known prey species of $H$. sanguineus. Halichondramide itself, is absent in all specimens of $H$. sanguineus, despite being the major metabolite of the sponge, ${ }^{258,261}$ so it has been suggested that the nudibranch is either secondarily converting halichondramide into compounds such as $\mathbf{7 4}$, or selectively excluding it. ${ }^{258}$ Since halichondramide is very cytotoxic $\left(\mathrm{LD}_{\mathrm{LO}}\right.$ in mice when injected subcutaneously is $\left.1.4 \mathrm{mg} \mathrm{kg}^{-1}\right),{ }^{261}$ it may be too potent for use by $H$. sanguineus.

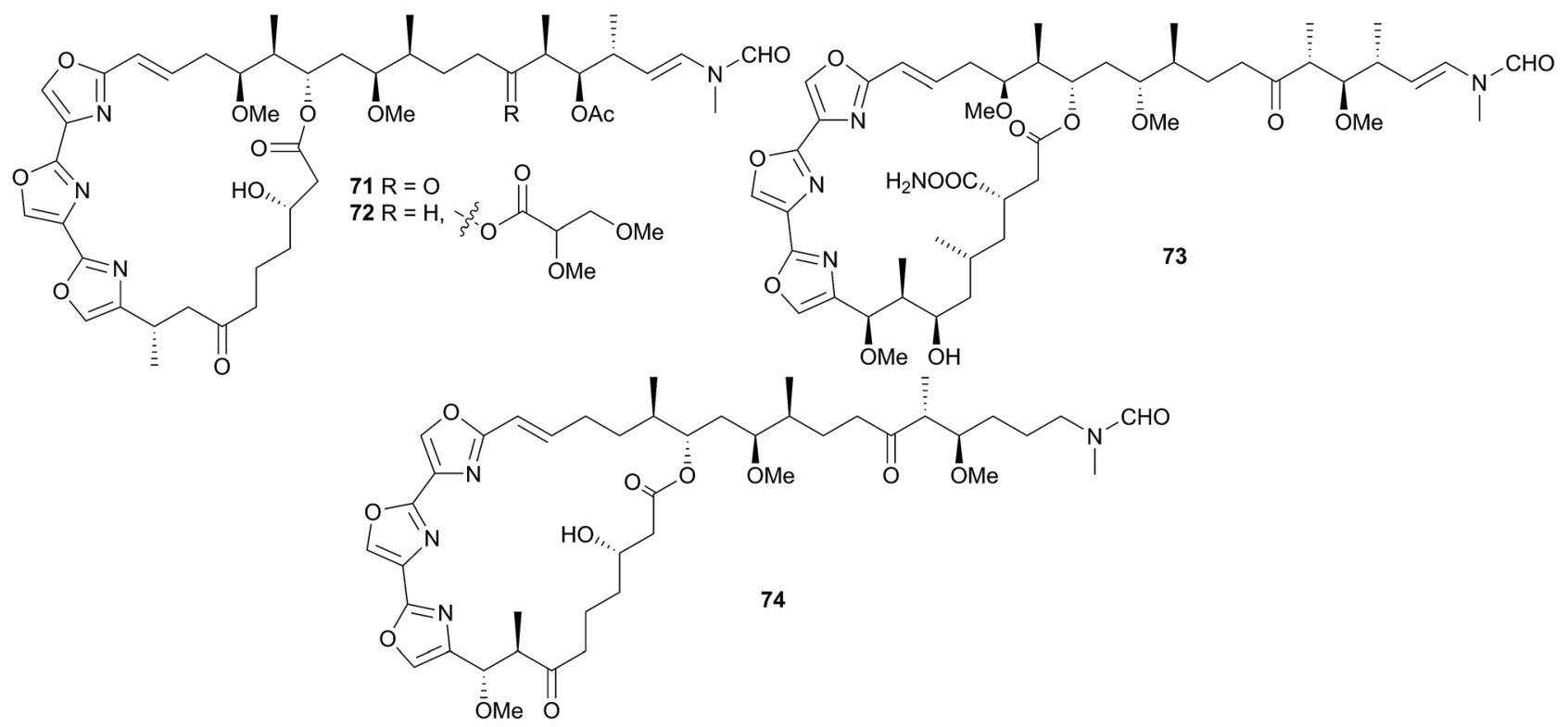

bioactivity testing and although it exhibited cytotoxicity against several HTCLs, it was 2-4 fold less potent than ulapualides A 71 and $\mathrm{B} 72 .{ }^{255}$

Other macrolides have also been isolated from $H$. sanguineus and its egg masses from various locations. These include kabiramide C (73) $)^{256-258}$ and related compounds ${ }^{256,258-260}$ and halichondramide derivatives ${ }^{258,260,261}$ such as dihydrohalichondramide (74). Ulapualides, kabiramides and halichondramide derivatives possessed a range of bioactivities, including cytotoxicity $^{254,255,260,261}$ and antifungal properties ${ }^{254,256,259,261}$ and the latter two macrolide families have been shown to deter feeding in both fish (Thalassoma lunare) and crabs (Dardunus megistos). ${ }^{258}$ Macrolides have been found at higher concentrations in egg masses than in the adult nudibranchs, ${ }^{254,258}$ suggesting that their main function is to protect these vulnerable egg masses, although it has been postulated that the macrolides are also secreted in the mucus of $H$. sanguineus thus conferring protection on the adult as well. ${ }^{258}$ One investigation has highlighted that the bioactivity of $\mathbf{7 1}$ (and hence presumably that of related
Hurghadin (75), the red pigment responsible for the colouration of $H$. sanguineus, has been isolated from an Egyptian specimen $^{263}$ and as it is a carotenoid, it is almost certainly sequestered. The occurrence of $\mathbf{7 5}$ in the mantle follows an inverse relationship with the known macrolides, indicating that it may provide an alternative chemical defence, in addition to acting as a visual warning to potential predators, ${ }^{263}$ although with no bioactivity studies conducted on 75 , this is only conjecture. The apocarotenoid apoastacenal was isolated from $H$. sanguineus egg masses from $\operatorname{Japan}^{264}$ as a new natural product (but known synthetic compound). ${ }^{265}$

$H$. sanguineus is a generalist feeder on many species of sponge. An adult specimen from the South China Sea was found to contain a mixture of nitrogenous sesquiterpenoids rather than macrolides, ${ }^{266}$ two of which were known metabolites from Axinella, Acanthella and Dysidea sponges, and two were novel. ${ }^{266}$ However, as both novel compounds were found in the digestive tract of the nudibranch, this suggests that they too are of dietary origin. 
A Fijian specimen of $H$. sanguineus analysed by very sensitive NMR spectroscopy (600 MHz spectrometer with a $1 \mathrm{~mm}$ hightemperature superconducting cryoprobe), yielded, in addition to a number of related macrolides, two thiazole cyclic peptides, sanguinamide A (76) and sanguinamide B (77). ${ }^{259}$ Both 76 and 77 were present at extremely low concentrations across the whole individual $(0.0023 \%$ and $0.011 \%$ dry weight respectively) suggesting that the compounds were not major components in $H$. sanguineus defence and likely represented metabolites of an as yet unidentified prey species. ${ }^{259}$ Although no dietary source has been identified for the sanguinamides, the structures suggest that cyanobacteria or tunicates may be their original source. $^{259}$ Both 76 (ref. 267) and 77 (ref. 68) have been synthesised; synthesis of the former revised the configuration to (76). Sanguinamide B analogues were active against Pseudomonas aeruginosa, reducing twitching motility. ${ }^{268,269}$ predatory nudibranch, feeds upon smaller nudibranchs, preferentially Tambja abdere and T. eliora, which in turn prey on the bryozoan Sessibugula translucens. Tambjamines A-D 78-81 were found in all four organisms, indicating their production by the bryozoan then sequestration and concentration up the food chain. ${ }^{270}$

Tambjamines have also been noted to deter feeding in fish, and thus likely act as a defence against both generalist and specialist feeders. ${ }^{271}$ Conversely, the Tambja nudibranchs and $R$. tigris have developed the ability to track their respective prey through chemoreception of these same compounds. ${ }^{271}$ In the slime trails of $T$. abdere, 78-81 were present at low concentrations, as well as being released in a mucus at relatively high concentrations when $T$. abdere was molested. ${ }^{270,271} R$. tigris was noted to track the slime trail of $T$. abdere, but would sometimes break off attack if the mucus was released, ${ }^{270}$ indicating that the

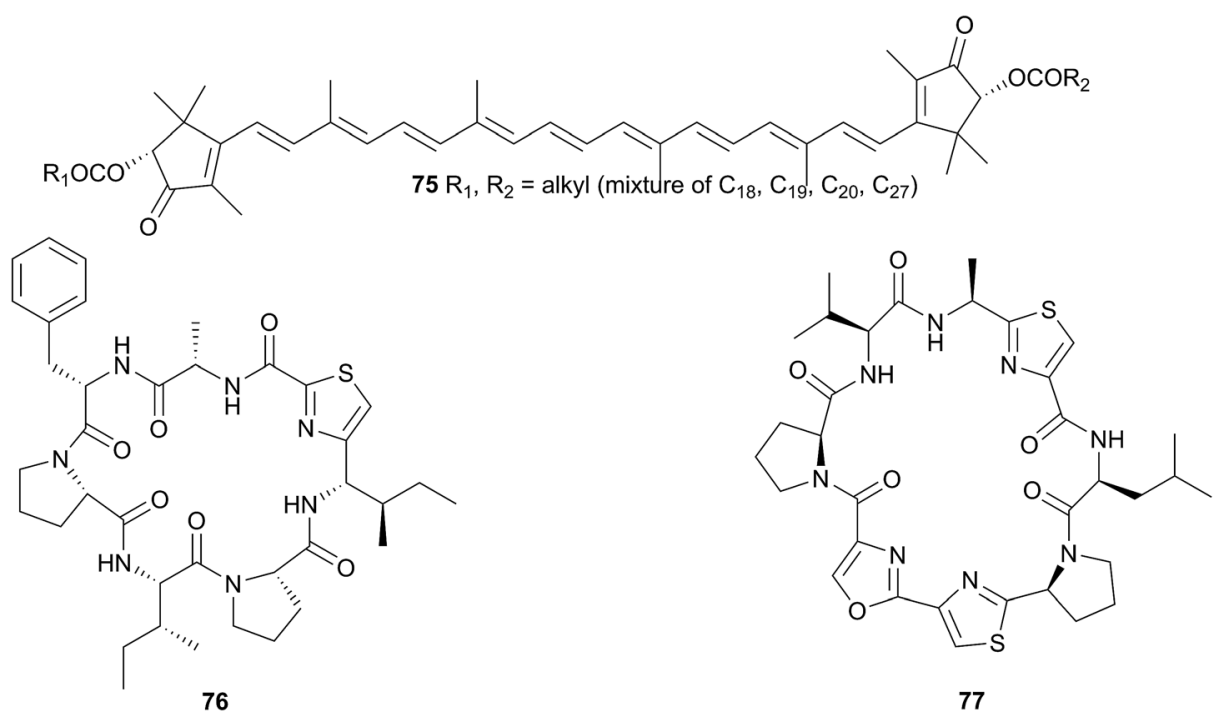

The implication of these studies, is that $H$. sanguineus can sequester a variety of metabolites to utilise in defence and can seemingly do so from a range of prey species. ${ }^{259,266}$

5.5.3 Polyceridae. The Polyceridae is comprised of three subfamilies, the Nembrothinae, the Polycerinae and the Triophinae. The Nembrothinae contains three genera, Nembrotha, Tambja and Roboastra, all of which utilise a series of antimicrobial and cytotoxic alkaloids, the tambjamines, which are known to be sequestered metabolites. ${ }^{270}$ Roboastra tigris, a large

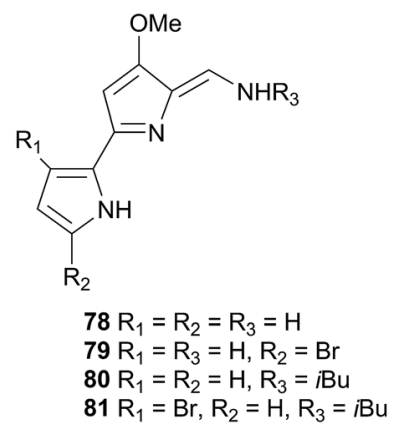

antifeeding properties of the tambjamines still affected $R$. tigris if their concentration was sufficient. ${ }^{271}$ In the event that T. eliora was attacked, it would attempt to flee rather than secrete a defence, suggesting that the lower concentration of tambjamines in $T$. eliora prevents release of a mucus. ${ }^{271}$ Similarly, $T$. eliora preferentially selected low concentrations of tambjamines (consistent with natural concentrations in S. translucens) in a Y maze, but was deterred if concentrations were high. ${ }^{271}$ Thus the tambjamines, in addition to being an antifeedant, in Tambja species, act as a tracking pheromone at low concentrations and an alarm pheromone at higher concentrations. ${ }^{271}$

Tambjamines, including 78-81 and new variants, have since been reisolated from $T$. eliora ${ }^{272}$ and from a bryozoan. ${ }^{273} \mathrm{~A}$ related yellow pigment was obtained from a bacterium ${ }^{274}$ and a related blue tetrapyrrole pigment was isolated independently from Nembrotha kubaryana, ${ }^{\mathbf{9 8}}$ a compound ascidian, ${ }^{275}$ a bryozoan $^{276}$ and from the predator-prey pairing Nembrotha spp. and the ascidian Atapozoa sp. ${ }^{277}$ and was identical to that produced by a mutant bacterium, ${ }^{278}$ indicating that it is likely of bacterial 
origin in all cases. Tambjamines have also been isolated from several predator-prey pairings; Tambja ceutae and the bryozoan Bugula dentata, ${ }^{\mathbf{2 7 9}}$ Tambja stegosauriformis and B. dentata ${ }^{\mathbf{1 3 7}}$ and from Nembrotha spp. and the ascidian Atapozoa sp. ${ }^{277,280}$ Some tambjamines, especially $\mathbf{8 1}$, have been investigated for pharmaceutical uses as they have been shown to be cytotoxic against a number of tumour cell lines. ${ }^{272,275}$ Proposed mechanisms for the cytotoxicity include intercalation into DNA as well as the promotion of single-strand DNA oxidative cleavage, although a lack of selectivity for tumour cells over healthy cells has been noted as a prominent obstacle to drug development. ${ }^{281}$

The Triophinae subfamily consists of nine genera of which only two (Triopha and Limacia) have been chemically examined. Two temperate nudibranchs from this subfamily, Triopha catalinae and Limacia clavigera also feed exclusively on bryozoans. $^{282,283}$ The structurally related triophamine $(\mathbf{8 2})^{282}$ and limaciamine $(\mathbf{8 3})^{\mathbf{2 8 3}}$ have been isolated from $T$. catalinae and $L$. clavigera respectively. Unlike the tambjamines, triophamine $\mathbf{8 2}$ has been shown to be de novo synthesised by T. catalinae $^{\mathbf{2 8 4 , 2 8 5}}$ and has also been isolated from a nudibranch in the closely related Polycerinae subfamily, Polycera tricolor. ${ }^{152}$ The geometry of the double bonds has been determined by total synthesis. ${ }^{286}$

The structural similarities between triophamine 82 and limaciamine $\mathbf{8 3}$ has led to speculation that $\mathbf{8 1}$ is also biosynthesised, ${ }^{283}$ but this has yet to be proven. As no bioactivity studies were conducted on these metabolites, their biological roles can only be speculated upon. The carotenoid triophaxanthin was first isolated as the main pigment of Triopha carpenteri $^{287}\left(T\right.$. catalinae $\left.^{\mathbf{4 1 4}}\right)$ but subsequent isolations from a tunicate ${ }^{288}$ and a cuttlefish ${ }^{289}$ and its presence in the gut of $T$. carpenteri, ${ }^{287}$ indicate that it is dietary in nature.
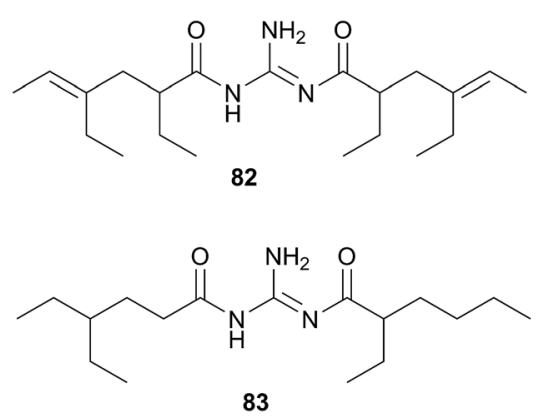

\section{Cladobranchs}

\subsection{Aeolidioidea}

The superfamily Aeolidioidea, comprises seven families but only two (Aeolidiidae and Facelinidae) have been studied. Despite this, the superfamily has attracted much attention from researchers, largely due to the genus Phyllodesmium, the only aeolid genus known not to sequester cnidocysts or nematocysts. ${ }^{290}$

6.1.1 Aeolidiidae. Of the nine genera comprising the Aeolidiidae family, a single species of each of three, Aeolidia, Aeolidiella (Berghia ${ }^{\mathbf{4 1 5}}$ ) and Spurilla has been chemically examined. When Aeolidia papillosa ate the sea anemone Anthopleura elegantissima, the alarm pheromone from A. elegantissima, anthopleurine, persisted in the nudibranch tissues for over five days. After this time, Aeolidia papillosa could evoke alarm responses in anemones without touching them, stimulating them to withdraw the tentacles and oral disk and to leave the body regions with the highest anthopleurine concentrations open to attack. ${ }^{291}$ Aeolidiella stephanieae (Berghia stephanieae ${ }^{\mathbf{4 1 5}}$ ) exclusively feeds on glass anemones of the Aiptasia genus which usually contain endosymbiotic dinoflagellates that provide nutrients such as fatty acids to their host. A study where breeding pairs of Berghia stephanieae were fed with either symbiotic or aposymbiotic Aiptasia pallida, revealed differences in the fatty acid profiles of their egg masses. ${ }^{292}$ An Argentinian collection of a number of individuals of Spurilla sp. revealed that the prey cnidocysts in the nudibranch cerata were highly variable in type and abundance and thus from a variety of sea anemone species. ${ }^{293}$

6.1.2 Facelinidae. Facelinidae is a large family of nudibranchs comprised of 34 genera. Representatives of just four of these genera (Cratena, Hermissenda, Phidiana and Phyllodesmium) have been studied chemically. Some prenylphenols were isolated from the skin of Cratena peregrina, ${ }^{294}$ two of which were found previously in a brown alga ${ }^{295}$ and in the digestive glands of another nudibranch, Dendrodoris grandiflora, ${ }^{212}$ indicating their dietary origin. Chitin was found in C. peregrina (and Flabellina affinis) as intracellular granules in skin epidermal cells and the epithelial cells of the stomach. ${ }^{296}$ These nudibranchs prey on Cnidaria and the chitin granules are released in response to nematocysts fired by prey tentacles and form aggregates with the nematocyst tubules, thus protecting the animals from the effects of the tentacles. In granular form, the chitin maintains skin flexibility while still conferring protection. ${ }^{296}$

L-6-Bromohypaphorine (84) was isolated from Hermissenda crassicornis and found to be an agonist of human $\alpha 7$ nicotinic acetylcholine receptor. ${ }^{297}$ A dietary origin of $\mathbf{8 4}$ is likely, as the compound has been found in the sponges Pachymatisma johnstoni $^{298}$ and Aplysina sp., ${ }^{299}$ as well as the tunicate Aplidium conicum. ${ }^{\mathbf{3 0 0}}$ Whilst $H$. crassicornis is largely considered a generalist feeder, a recent report noted a preference for colonial tunicates in its diet, especially Aplidium solidum. ${ }^{301}$ It would therefore seem likely that the source of $\mathbf{8 4}$ in the nudibranch is from either A. conicum itself or another Aplidium species.

Two indole alkaloids, phidianidines A (85) and B (86), were isolated from Phidiana militaris and were cytotoxic against a number of cell lines, including C6 and HeLa tumour cells. ${ }^{302}$ They remain to date, the only known marine natural products with the 1,2,4-oxadiazole core. The rarity of this backbone, coupled with the total lack of any precursor metabolite in a known prey species, precludes the possibility of $P$. militaris sequestering 85 and 86 . Whilst de novo synthesis might therefore be suspected, isotope studies are needed for confirmation. If isotope studies fail to show evidence of biosynthesis, then an unidentified prey species must possess the metabolites, or precursors thereof, or the source could potentially be a symbiotic organism. The biological activity of 85 and 86 coupled with their structural rarity, have led to syntheses of the natural 
products $^{303-306}$ and analogues ${ }^{307-309}$ for exploration of their neuroprotective effects. ${ }^{303-309}$

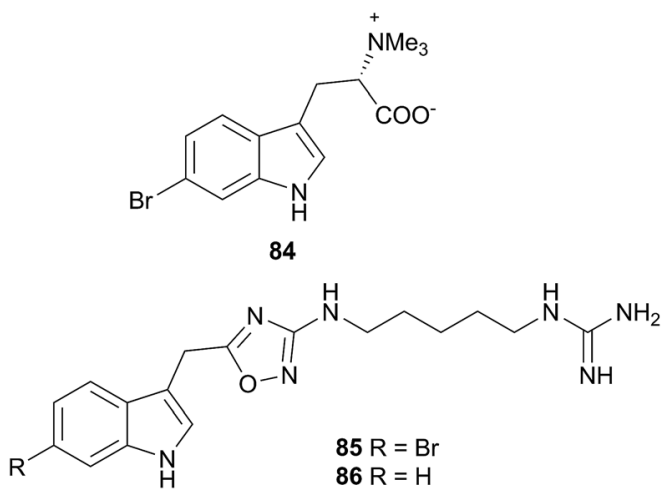

The genus Phyllodesmium is the only aeolid genus known not to sequester cnidocysts or nematocysts. ${ }^{290}$ Without the physical defence utilised by many aeolids, it might be expected that Phyllodesmium sp. would obtain a chemical defence in its place and indeed, this has been shown to be the case. ${ }^{\mathbf{2 9 0 , 3 1 0 - 3 1 2}}$ The cytotoxic diterpene trocheliophorol (87) was isolated from Phyllodesmium longicirra ( $P$. longicirrum ${ }^{418}$ ) and the soft coral Sarcophyton trocheliophorum, upon which it was found. ${ }^{310}$ The cerata of the nudibranch were concentrated with $\mathbf{8 7}$ and were noted to detach when molested, suggesting that $P$. longicirra was sequestering a defensive metabolite. ${ }^{310}$ Similarly, Phyllodesmium guamensis ( $P$. guamense $^{\mathbf{4 1 6}}$ ) was also found grazing upon soft corals; Sinularia maxima, S. polydactyla and an unidentified Sinularia species. ${ }^{\mathbf{3 1 1}}$ The diterpene 11 $\beta$-acetoxypukalide (88) was sequestered from these corals by $P$. guamense and concentrated in its cerata. Diterpene $\mathbf{8 8}$ deterred feeding by the predatory pufferfish Canthigaster solandri at concentrations lower than those found in the cerata. ${ }^{\mathbf{3 1 1}}$ Four polycyclic diterpenes were isolated from a single specimen of Phyllodesmium longicirrum from the Great Barrier Reef, Australia, of which 4-oxochatancin (89) deterred feeding by Canthigaster solandri. ${ }^{313}$ Although the food source of the nudibranch was not collected, it was noted that $P$. longicirrum usually feeds on soft coral of the Sarcophyton genus. ${ }^{313}$ This, coupled with 89 possessing a planar structure the same as that of isosarcophytin from Indian Ocean S. elegans ${ }^{\mathbf{3 1 4}}$ but stereochemistry the same as that of chatacin $^{315}$ from an Okinawan Sarcophyton sp., means that 89 is very likely a sequestered metabolite.

Sesquiterpenes are also sequestered by Phyllodesmium aeolids. Those obtained from $P$. lizardensis ( $P$. lizardense ${ }^{\mathbf{4 1 7}}$ ), were also found at an elevated concentration in the cerata ${ }^{290}$ and their dietary source was found to be a coral of the Heteroxenia genus. Although these sesquiterpenes were inactive in antifungal, antibacterial or antialgal assays and were not tested for feeding deterrence, a related compound, (+)-6-hydroxy- $\alpha$ muurolene, has been found to be lethal to brine shrimp. ${ }^{312} \mathrm{~A}$ mixture of eight diverse sesquiterpenes was also isolated from $P$. magnum, including a novel asteriscane terpene $(\mathbf{9 0}) \cdot{ }^{316}$ Of the remaining seven metabolites, four were known from corals of the Sinularia genus and three were known from the brown alga Dictyopteris divaricata, ${ }^{316}$ suggesting sequestration and that $P$. magnum may graze upon corals as well as brown algae. Whilst
90 was a novel natural product, a more recent study of Sinularia capillosa highlighted compounds with similar backbones, ${ }^{\mathbf{3 1 7}}$ indicating that 90 may be a metabolite of an unidentified Sinularia sp., or be otherwise secondarily modified, as opposed to being biosynthesised de novo.
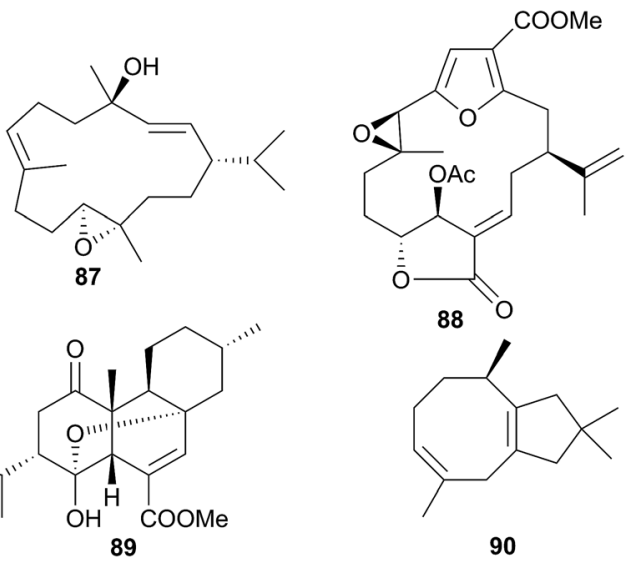

\subsection{Arminoidea}

Consisting of the two families, Arminidae (seven genera) and Doridomorphidae (one genus), this superfamily has received minimal attention from natural products researchers, with only two species of the Arminidae (Armina and Dermatobranchus) being investigated to date. A series of seven briarane diterpenes, including the chlorinated example 91, was isolated from the nudibranch Armina maculata and its octocoral prey Veretillum cynomorium $^{\mathbf{3 1 8 - 3 2 0}}$ as was a cembranoid, preverecynarmin (92), ${ }^{320}$ highlighting that all were of dietary origin for the nudibranch. Similarly, four related diterpenoids, ophirin (93), calicophirin B (94), 13-deacetoxyl calicophirin B (95) and 13-deacetoxy-3deacetyl calicophirin B (96), were isolated from the nudibranch Dermatobranchus ornatus. ${ }^{321}$ Of these, 94 and 95 were subsequently found within a prey species, a gorgonian of the Muricella genus. ${ }^{321}$ This indicated that these compounds may be of dietary origin, with 93 and 96 being sourced from an unidentified prey species or otherwise secondarily modified.

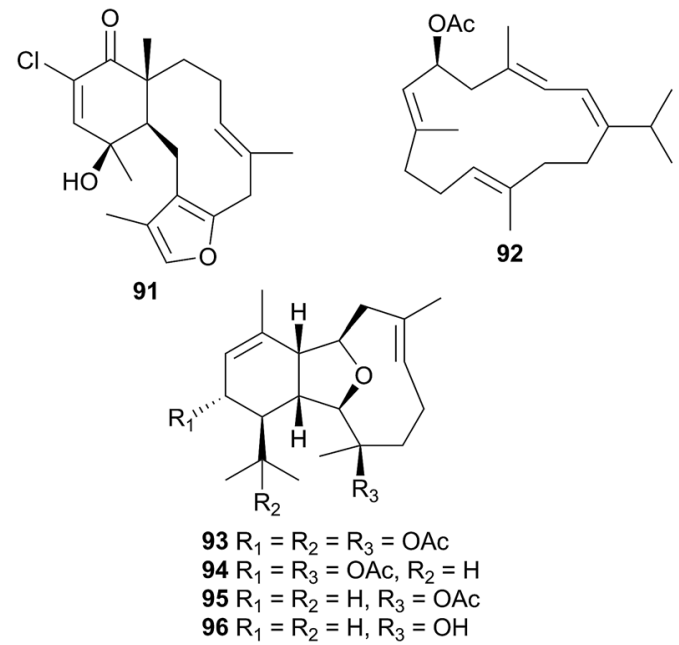




\subsection{Doridoxoidea}

Of the unassigned Cladobranchs, there has been one superfamily designated, the Doridoxoidea which in turn consists of one family (the Doridoxidae) containing one genus (Doridoxa). Under former classification systems, ${ }^{12}$ Doridoxoidea was not strictly a cladobranch, but evidence emerged to suggest that this superfamily should be included under Cladobranchia, ${ }^{15}$ and it is now classified as such. ${ }^{13}$ There have been no natural product studies of Doridoxoidea species, possibly as they, like the Bathydoridoidea, are polar, deep water nudibranchs and are thus considerably more difficult to collect. $^{\mathbf{1 2}}$

\subsection{Fionoidea}

This superfamily contains the families Fionidae and Pseudovermidae but has barely been examined. A study of Phestilla melanobranchia (Tenellia melanobranchia ${ }^{\mathbf{4 1 9}}$ ) (Fionidae) which feeds on the coral Tubastrea coccinea, yielded the known sponge alkaloids, $4^{\prime}$-de- $N$-methylaplysinopsin (97) and 6-bromo-4'-de- $N$ methylaplysinopsin (98), which were also obtained from the prey coral. $^{322}$ A study of Phestilla sibogae (Tenellia sibogae ${ }^{\mathbf{4 2 0}}$ ) highlighted that the nudibranch can track its coral prey through chemoreception using its rhinophores ${ }^{4}$ but the study did not involve isolating any metabolites that could potentially be implicated. The researchers noted that the rhinophores responded to various amino acids, with the most intense responses to aspartic and glutamic acids, ${ }^{4}$ so suggested that $P$. sibogae tracked corals through amino acids. ${ }^{4}$ However, as no natural product investigations have been conducted, the possibility remains that the nudibranch may detect and respond to secondary metabolites in corals that it wishes to sequester. After all, tracking of metabolites is not unprecedented in nudibranchs, as the response of Roboastra tigris to the tambjamines highlights (see Section 5.5.3 above). ${ }^{270}$

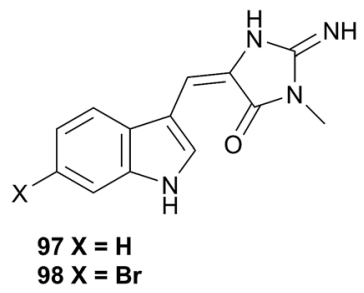

\subsection{Flabellinoidea}

The Flabellinoidea is divided into two families, the Flabellinidae (eight genera including Flabellina and Flabellinopsis) and the Notaeolidiidae (one genus) but there has been very little chemical research into these nudibranchs. As noted above, chitin was found in skin epidermal cells and the epithelial cells of the stomach of Flabellina affinis as intracellular granules. ${ }^{296} \mathrm{~F}$. affinis was also noted to feed and lay its eggs upon several species of hydroid of the Eudendrium genus and to contain the same polyhydroxylated sterols as the hydroid but only the major component of this sterol mix was isolated and only from the hydroid. ${ }^{323}$ The ubiquitous carotenoid astaxanthin ${ }^{324}$ was found in Flabellinopsis iodina and its sponge diet. ${ }^{287}$

\subsection{Tritonioidea}

Nudibranchs of this superfamily, sometimes referred to as dendronotoids, are further separated into nine families, of which only two, the Tethydidae (two genera) and the Tritoniidae (nine genera) have received any attention from natural product chemists.

6.6.1 Tethydidae. Tethydidae, comprises two genera; (Melibe and Tethys) and natural product biosynthesis has been observed in both. ${ }^{325,326}$ Nudibranchs of this family are unusual in that they do not feed on sessile, benthic organisms, but rather on free swimming planktonic crustaceans. ${ }^{7,325}$ They have developed an extended oral veil which acts as a net to sweep up their prey, and are noted to swim freely in the water column. ${ }^{325}$ Melibe leonina is found along the entire coastline of Northern America and is noted to have a fruity aroma. ${ }^{327}$ Degraded terpenoids, 2,6-dimethyl-5heptenoic acid (a known synthetic compound) ${ }^{328}$ and 2,6dimethyl-5-heptenal ${ }^{325}$ (99), were isolated from the nudibranch, of which 99 was found to be the source of this scent. De novo synthesis was confirmed via stable isotope feeding studies. ${ }^{325}$ Whilst no bioactivity studies of $\mathbf{9 9}$ were conducted, a potential sea star predator (Pyncnopodia helianthoides) was repelled upon contact with $M$. leonina. ${ }^{325}$ The complete mitochondrial genome of M. leonina has recently been determined. ${ }^{329,330}$

Prostaglandin (PG) lactones have been isolated from the related species Tethys fimbria ${ }^{\mathbf{3 2 6 , 3 3 1}}$ which is known to synthesise some of these de novo. ${ }^{326,332}$ These are synthesised from, and act as protected forms of, the free PG acids, ${ }^{326}$ compounds known to promote a range of hormonal responses in many organisms. PG molecules are classified by the structure of their central ring system, donated by a letter, which indicates the membrane protein that the PG will interact with. ${ }^{333}$ A subscript indicates the number of double bonds present in the aliphatic side chains. $T$. fimbria synthesises and stores PG lactones of the E class, $\mathrm{PGE}_{2}$ 1,15-lactone (100) and $\mathrm{PGE}_{3}-1,15$-lactone (101), in its cerata. ${ }^{326}$ When molested, T. fimbria emits a mucus from its body and cerata and if the cerata become detached, they can continue to release mucus for a number of hours. When molested, the nudibranch converted 100 and 101 back to the free acid forms $\mathrm{PGE}_{2}(\mathbf{1 0 2})$ and $\mathrm{PGE}_{3}(\mathbf{1 0 3})$ respectively, ${ }^{326}$ suggesting that the free acid forms 102 and 103 were being utilised in the nudibranch's defence. PGlactones of the $\mathrm{F}$ series have also been detected in T. fimbria (not pictured, but $9(S)$-hydroxy derivatives of $\mathbf{1 0 0}$ and $\mathbf{1 0 1})^{332}$ but are only present in the ovotestis (hermaphroditic gland of the nudibranch) and not the cerata, indicating that they may play a role in reproduction as opposed to defence. ${ }^{332}$

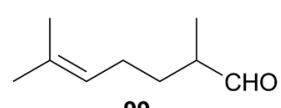

99
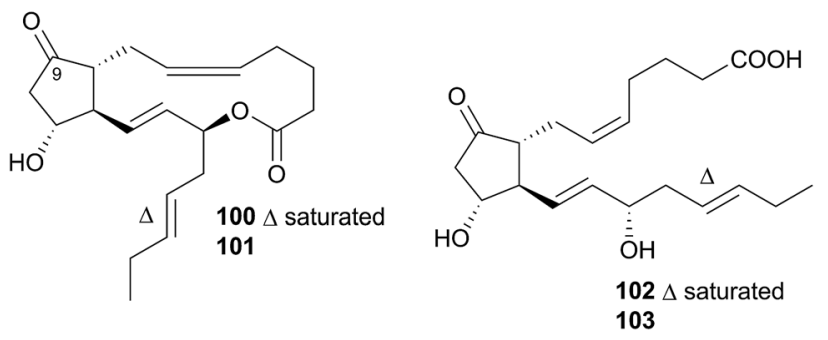
6.6.2 Tritoniidae. The most diverse of the Tritinoidea families is Tritoniidae. Comprising nine genera, these nudibranchs are noted to sequester metabolites from their prey. ${ }^{334,335}$ The macrolactone amphidinolide $\mathrm{P}(\mathbf{1 0 4})$, was isolated from the octocoral Stragulum bicolor and its nudibranch predator Marionia limceana from Brazil. ${ }^{335}$ Prior to this isolation, $\mathbf{1 0 4}$ has only been isolated from laboratory cultures of the marine dinoflagellate Amphidinium sp..$^{336}$ but $S$. bicolor appears to host a diverse but so far uncultivable dinoflagellate community and $\mathbf{1 0 4}$ was present in much higher concentration in the octocoral than was reported in Amphidinium sp. Although 104 was passed up trophic levels to Marionia limceana, no evidence was presented that it was actively sequestered and despite it having been reported as possessing moderate cytotoxicity, ${ }^{336} \mathbf{1 0 4}$ was found to be inactive when tested against the HCT-116 cell line in this study. ${ }^{335}$
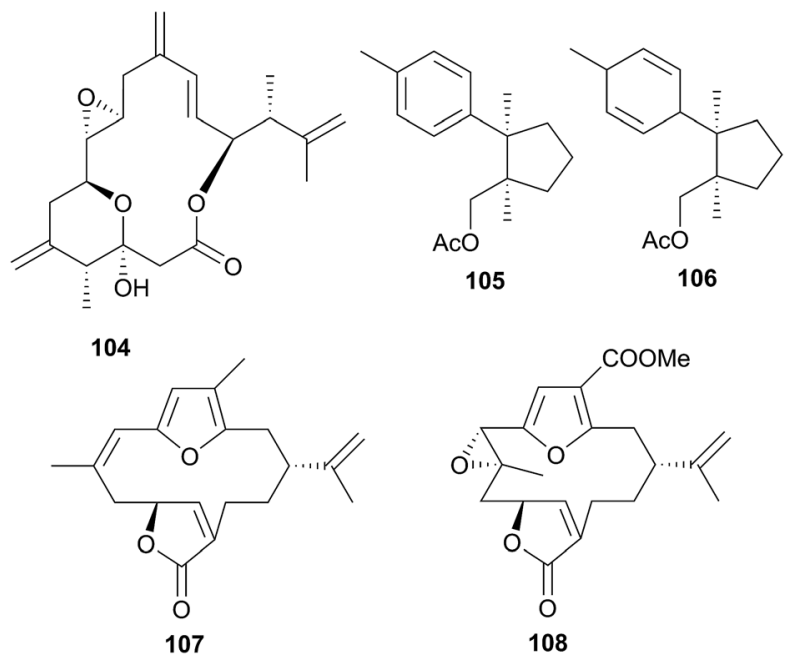

A series of six terpenoid metabolites has been isolated from two nudibranch populations of Tochuina tetraquetra ${ }^{337}$ (T. gigantea $^{\mathbf{4 2 3}}$ ). Specimens from Port Hardy, British Columbia were noted to contain tochuinyl acetate (105), dihydrotochuinyl acetate (106), rubifolide (107) and pukalide (108). Analysis of a prey species, the soft coral Gersemia rubiformis, present at Port Hardy, indicated that $\mathbf{1 0 5}$ and $\mathbf{1 0 6}$ were minor metabolites of this species. Rubifolide $\mathbf{1 0 7}$ had been previously detected in $G$. rubiformis. ${ }^{338}$ Whilst a known source of $\mathbf{1 0 8}$ was not found at Port Hardy, it has been previously reported from tropical corals, Sinularia, ${ }^{339}$ and gorgonians of the genus Lophogorgia. ${ }^{337}$ A second collection of $T$. tetraquetra, from Bamfield, British Columbia, revealed the diterpenoid ptilosarcenone (109) and its butanoate analogue (110). ${ }^{337}$ The sea pen Ptilosarcus gurneyi, a prey species of $T$. tetraquetra in Bamfield waters, is known to produce 109. ${ }^{340}$ As it appears that the nudibranch sequesters natural products from various prey species, ${ }^{337}$ it is therefore not surprising that the geographically separated populations possess different compositions of natural products.

Tritonia hamnerorum was observed on its prey, the sea fan Gorgonia ventalina at very high densities, in the Florida Keys, U.S.A., resulting in the isolation of the furano-germacrene julieannafuran (111) from both sea fan and nudibranch. T. hamnerorum concentrated $\mathbf{1 1 1}$ relative to other sea fan metabolites and $\mathbf{1 1 1}$ either significantly reduced or entirely prevented reef fish feeding on the nudibranch in both natural and laboratory environments. ${ }^{341}$

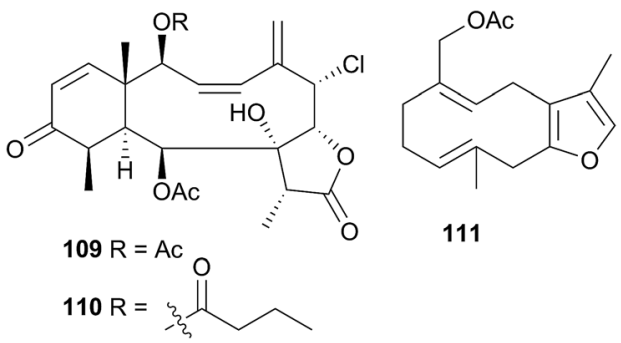

1-O-Hexadecyl glycerol (chimyl alcohol) was detected in the Antarctic nudibranch Tritoniella belli and its usual prey, the stoloniferan coral Clavularia frankliniana. The common predatory Antarctic sea star Odontaster validus, showed feeding deterrence to both $T$. belli mantle tissue and to chimyl alcohol. ${ }^{342}$ A series of sesquiterpenes, tritoniopsins A-D (112-115), were isolated from the nudibranch Tritoniopsis elegans and its soft coral prey Cladiella krempfi. ${ }^{334}$ The major metabolites in both species were found to be 112 and 113 but the relative ratio of these was inverted in the predator-prey pair, such that $\mathbf{1 1 2}$ dominated the T. elegans extract and 113 dominated the extract of C. krempfi. Tritoniopsin A 112 was concentrated within the mantle tissue of $T$. elegans, to a greater degree than were 113-115, suggesting that 112 plays a defensive role for the nudibranch and that it was preferentially sequestered from the coral. No bioassays were conducted for 112, but weak to moderate cytotoxicity was observed for tritoniopsin B 113 against a selection of rat cell lines. ${ }^{334}$
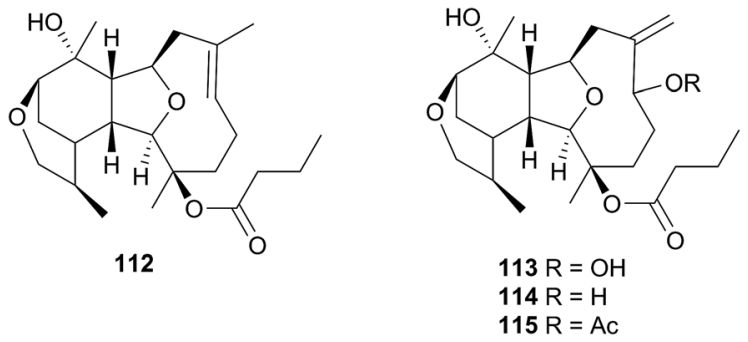

\subsection{Unassigned families}

6.7.1 Charcotiidae. Only three of the nine unassigned families have been subject to natural products investigations. The first, Charcotiidae, contains three genera (Charcotia, Leminda and Pseudotritonia) and only the Antarctic nudibranch Charcotia granulosa and the tropical nudibranch Leminda millecra have been examined chemically. Granuloside (116), a homosesterterpene lactone, was isolated from the Antarctic nudibranch Charcotia granulosa. ${ }^{343}$ Whilst sesterterpenes are known in some dorid nudibranchs, granuloside (116) is the only known linear homosesterterpene in all of nature. ${ }^{343}$ It was isolated from the lipophilic extract of the external part of the nudibranch and was absent in the gut and the digestive gland. Additionally, neither 116 nor any related compound was found in the specialist prey of the nudibranch, 
the bryozoan Beania erecta, strongly suggesting a de novo biosynthetic origin. ${ }^{344}$

L. millecra is known to sequester sesquiterpenes. ${ }^{345,346}$ Millecrones A (117) and B (118), as well as millecrols A (119) and B (120), were isolated from a South African population of $L$. millecra ${ }^{345}$ Analysis of the nudibranch's stomach contents revealed spicules from the soft corals Alcyonium foliatum, A. valdiviae and Capnella thyrsoidea.$^{345}$ Limited antimicrobial activity was noted for 117, 119 and 120. A separate analysis of another South African population of $L$. millecra and its local prey, identified the dietary origin of 117 and $118 .^{346} \mathrm{GC}$ analysis indicated that 117 originated from the soft coral Alcyonium fauri, whilst $\mathbf{1 1 8}$ was from the gorgonian Leptogorgia palma. ${ }^{346}$ At least eleven other sesquiterpenes were detected (structures not shown) in the latter study by GC. These were also expected to be of dietary origin, from various octocoral prey species, due to the backbone common with typical octocoral metabolites. ${ }^{346}$ Some of the triprenylated toluquinones and toluhydroquinones obtained from Leminda millecra induced apoptosis in oesophageal cancer cell lines. ${ }^{347}$
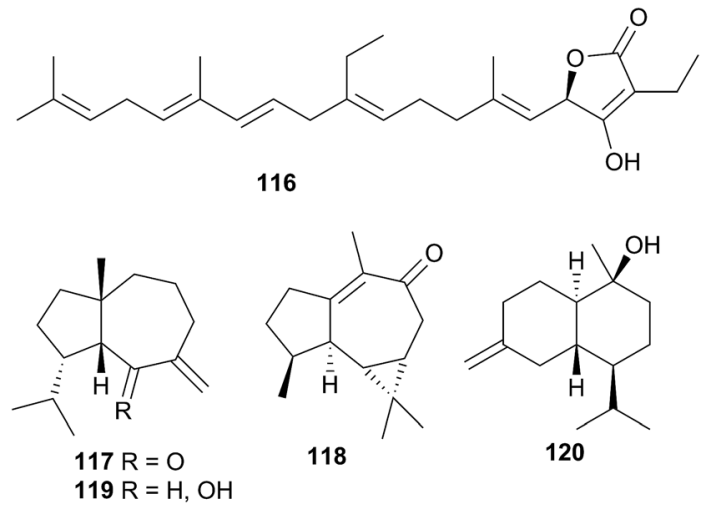

6.7.2 Dotidae. Members of the Dotidae family (comprising four genera) have been reported to feed exclusively on hydrozoans. ${ }^{348}$ Only one species from this family has been chemically studied. A Spanish collection of Doto pinnatifida yielded dotofide (121), a guanidine-interrupted terpenoid ${ }^{348}$ but 121 was not found in the hydrozoan Nemertesia antennina, the exclusive prey of D. pinnatifida, suggesting the likelihood of de novo biosynthesis. ${ }^{348}$ A new species, $D$. carinova has recently been described and compared with $D$. antarctica but as yet, no chemistry has been reported for either species. ${ }^{349}$

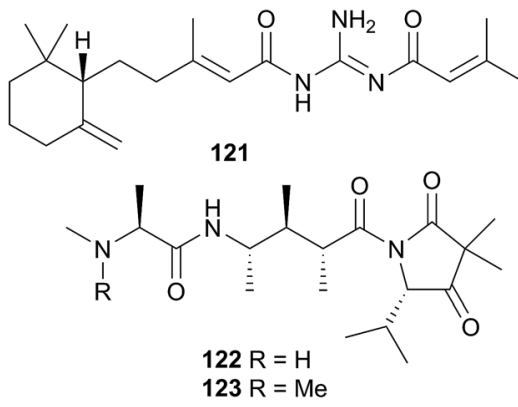

6.7.3 Proctonotidae. Of the five genera comprising the Proctonotidae family, only Janolus has been studied. The tripeptide janolusimide (122) was isolated from the

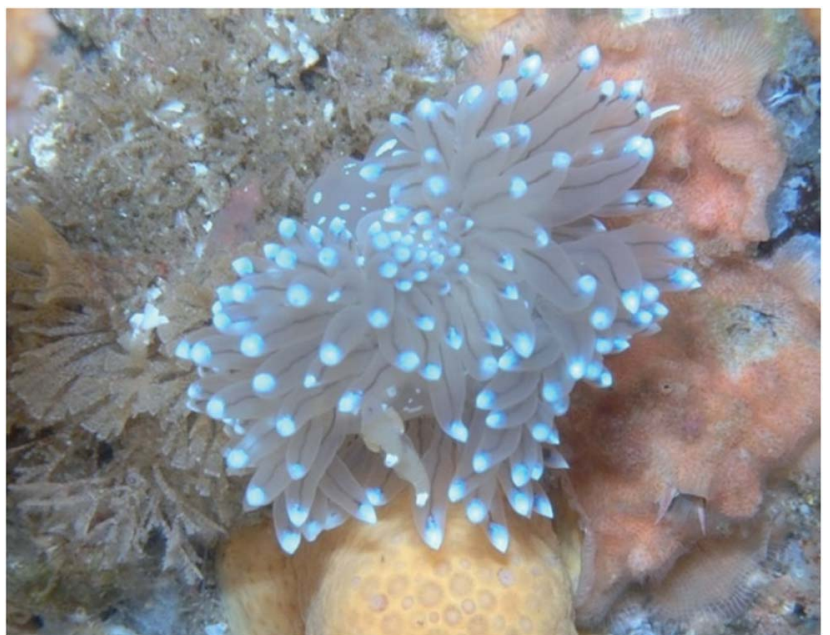

Fig. 3 Janolus cristatus feeding on Bugulina flabellata in the Shetland Islands. Photograph courtesy of Joanne Porter.

Mediterranean nudibranch Janolus cristatus. ${ }^{350}$ Janolusimide (122) was toxic to mice (LD $5 \mathrm{mg} \mathrm{kg}^{-1}$; i.p.) and antagonism of its neurotoxic action at lower concentrations by atropine suggested that 122 affects the acetylcholine receptors. ${ }^{350}$ More recently, an $N$-methyl analogue of $\mathbf{1 2 2}$, janolusimide B (123) was isolated from a New Zealand population of the bryozoan, Bugula flabellata $^{351}$ (Bugulina flabellata ${ }^{352}$ ) from Stewart Island. This bryozoan is native to the British Isles but has since spread to Australasia, the western coastline of the U.S.A. and throughout the Atlantic and Mediterranean. In New Zealand at least, it is considered a fouling "weed" for all intents and purposes. ${ }^{353}$ The structural similarity between 122 and 123 suggested an ecological interaction between $J$. cristatus and B. flabellata. ${ }^{351}$ Indeed, J. cristatus is known to feed predominantly on bryozoans, including B. flabellata (Fig. 3). ${ }^{354}$ However, as $\mathbf{1 2 2}$ was never identified in the bryozoan, and $\mathbf{1 2 3}$ was never found in the nudibranch, it was unclear if $J$. cristatus sequestered 122 from its diet or secondarily modified it from 123.

A subsequent investigation into a different New Zealand population of B. flabellata found evidence of both $\mathbf{1 2 2}$ and $\mathbf{1 2 3}$ within the bryozoan. ${ }^{355}$ Small scale extraction of New Zealand collections of Janolus novozealandicus and Bugulina flabellata and screening of the extracts by tandem liquid chromatography mass spectrometry (LCMS) indicated the presence of both $\mathbf{1 2 2}$ and $\mathbf{1 2 3}$ and suggested the presence of a series of at least six related tripeptides. The relative abundance of $\mathbf{1 2 2}$ and $\mathbf{1 2 3}$ is inverted within J. novozealandicus (122 dominant) with respect to B. flabellata (123 dominant) suggesting preferential uptake of 122. An egg mass of $J$. novozealandicus was also extracted and screened and of the two tripeptides, only $\mathbf{1 2 2}$ was found (as the main metabolite), highlighting its potential role as a defensive compound, ${ }^{355}$ although further studies are needed to confirm this.

\section{Nematocysts and zooxanthellae}

Sequestration of whole organisms (zooxanthellae) or nematocysts by some aeolid nudibranchs has been given its own 
section as, strictly speaking, it is not natural products chemistry. Nevertheless these processes deserve a brief mention. As has already been noted, virtually all aeolid species except those of the Phyllodesmium genus are known to sequester the stinging cells from their cnidarian prey. ${ }^{\mathbf{9 , 2 9 0}}$ The nematocysts are taken up by the aeolids and transported to the tips of cerata where multiple cells are incorporated into a single cnidosac. ${ }^{9}$ The use of a cnidosac is almost certainly in defence, as aeolids which have had their cerata removed are considerably more likely to be consumed. In most species, the cerata are also known to regenerate, indicating that they serve an important function to the aeolids. ${ }^{9}$ The exact mechanisms by which the nudibranch is able to protect itself from the sting of these cells are not fully understood. ${ }^{9,356}$ The presence of epithelial linings within the viscera has been observed and noted to absorb the damage from a discharged nematocyst, thus protecting the nudibranch. ${ }^{9}$ Application of aeolid mucus to the sea anemone Anthopleura elegantissima lowered the number of nematocyst discharges, with respect to mucus of other nudibranchs. ${ }^{9}$ This highlighted that aeolids used multiple strategies to cope with the stinging cells. A relatively recent study tested the hypothesis that aeolids transfer immature nematocysts to the cnidosacs and then allow them to mature, thus avoiding the potential damage caused by transporting a charged nematocyst. ${ }^{356}$ Utilising a fluorescent dye, researchers were able to show that there was a change in $\mathrm{pH}$ as the nematocysts were incorporated into the cnidosacs. As an accumulation of protons is necessary for nematocysts to mature, this supported the hypothesis that aeolids themselves were maturing the nematocysts. ${ }^{356}$

Whilst sequestration of nematocysts is common in all aeolids except those of Phyllodesmium, an interesting symbiotic relationship has been observed in a number of cladobranchs. Zooxanthellae, photosynthetic dinoflagellates, are frequently found within the cells of cladobranchs' branched digestive gland. ${ }^{357}$ This symbiosis has been observed in a number of Phyllodesmium species and may highlight why this genus does not sequester nematocysts. ${ }^{357,358}$ Aeolids of the Phestilla (Tenellia ${ }^{\mathbf{4 1 9 4 2 0}}$ ) (Fionidae family) and Pteraeolidia (Facelinidae family) have also been noted to possess zooxanthellae symbionts. A number of non-aeolid cladobranchs also obtain these symbiotic organisms, namely the dendronotoids of Melibe and Doto genera as well as Doridomorpha gardineri (Doridomorphidae family) and Pinufius rebus (unassigned Cladobranchia, Superfamily Arminoidea, Family Pinufidae). ${ }^{357,358}$ The advantages offered to these cladobranchs are obvious, in that the transfer of (primary) metabolites can enhance survivability if food is scarce. ${ }^{357}$ Interestingly, there have been no reported cases of zooxanthellae symbiosis within any of the dorid nudibranchs. This is presumably because their unbranched digestive gland and lack of cerata (or similar projections) limits the available surface area for zooxanthellae photosynthesis.

\section{Conclusions}

The natural products chemistry of nudibranchs is extensive and well documented. Terpenes and sesquiterpenes in particular, dominate those metabolites that have been isolated, although virtually all classes of natural products are represented. The sequestering of these metabolites from prey species is seemingly the most common source of nudibranch natural products. Indeed, metabolites have been sequestered from sponges, corals, tunicates, gorgonians and bryozoans. Whilst de novo synthesis is rarer than sequestration of natural products, it can still be found throughout all of Nudibranchia. Secondary modification is also suspected in a number of cases. Unsurprisingly, terpenes still dominate the types of structures observed.

It is certainly true that dorids have received considerably more research attention than their cladobranch counterparts. This is perhaps due to a perceived notion that cladobranchs, especially aeolids, utilise a physical defence (cnidosacs) over a chemical one. Furthermore, many dorids are known to feed exclusively on sponges, and sponges themselves are known to be the most prolific producers of marine natural products, ${ }^{36 c}$ so the natural products chemistry of those dorids that feed on sponges might also be expected to be rich in metabolites. However, as this review has highlighted, natural products are found within all branches of Cladobranchia (that have been studied). De novo synthesis is known within the dendronotoids and suspected in some aeolids. There have even been reports of unprecedented novelty, including the first examples of marine metabolites with a 1,2,4oxadiazole core $(\mathbf{8 5} \text { and } \mathbf{8 6})^{\mathbf{3 0 2}}$ as well as the first known linear homosesterterpene (116). ${ }^{343}$ These examples challenge the historical notion that the dorids represent the greatest source of nudibranch natural products. In light of this, more investigations into cladobranchs should be conducted moving forwards.

Even within the dorid nudibranchs, there has been an uneven allocation of research attention. Certainly the Doridoidea are well represented but many of these investigations are from species of a single genus, Chromodoris. Similarly, Hexabranchus sanguineus, has received considerable attention but no reports into other Hexabranchus species have been carried out. This preference of some superfamilies and some species over others means that there are still many nudibranchs to be properly studied. Perhaps the biggest message to be gained from this review, is that very few natural products have proven ecological roles. Indeed in some cases, only structures have been reported with absolutely no consideration for their bioactivity. Of all the metabolites presented within this review for which an ecological role is known or suspected, all but the PGF-lactones isolated from Tethys fimbria, are used in defence. Although the defensive capabilities of natural products are assumed in many cases, very few have been shown to actually deter predation. However, proving a chemical ecological role is not a simple task. Typically this requires dissection of the nudibranch into its mantle, viscera and other parts, instead of whole organism extraction, as well as conducting a number of antifeeding tests and bioassays. In many cases, natural product investigations are pharmaceutically driven and the chemical ecology is only of secondary interest. Thus, extensive ecological studies are relatively rare in the literature, given the time and amount of metabolite required to adequately perform these experiments. 
Table 1 Current classification (WoRMS) of nudibranchs covered in this review

\section{Reported}

Superfamily

Family

Subfamily

Genus

Species

Reclassification or (correction)

Dorids

Bathydoridoidea

Doridoidea
Bathydorididae

Actinocyclidae

Cadlinidae

Chromodorididae

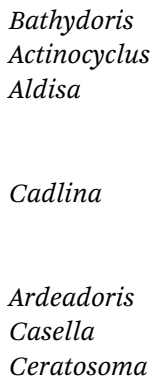

Chromodoris

Felimida

Glossodoris

Goniobranchus

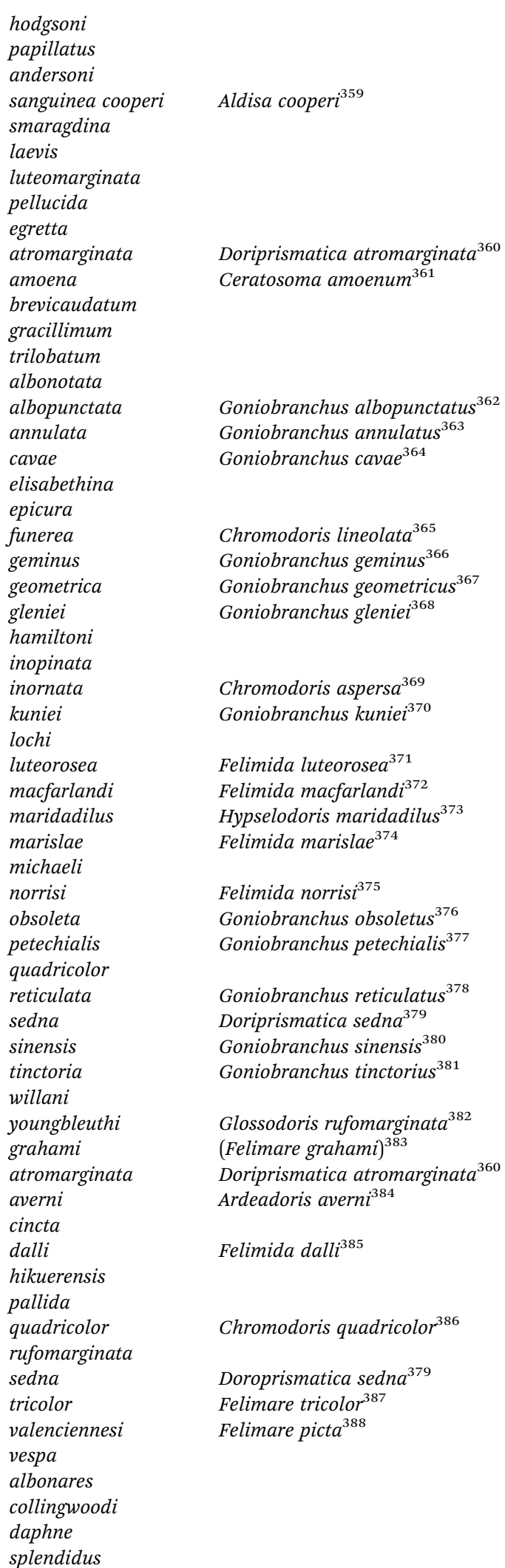


Table 1 (Contd.)

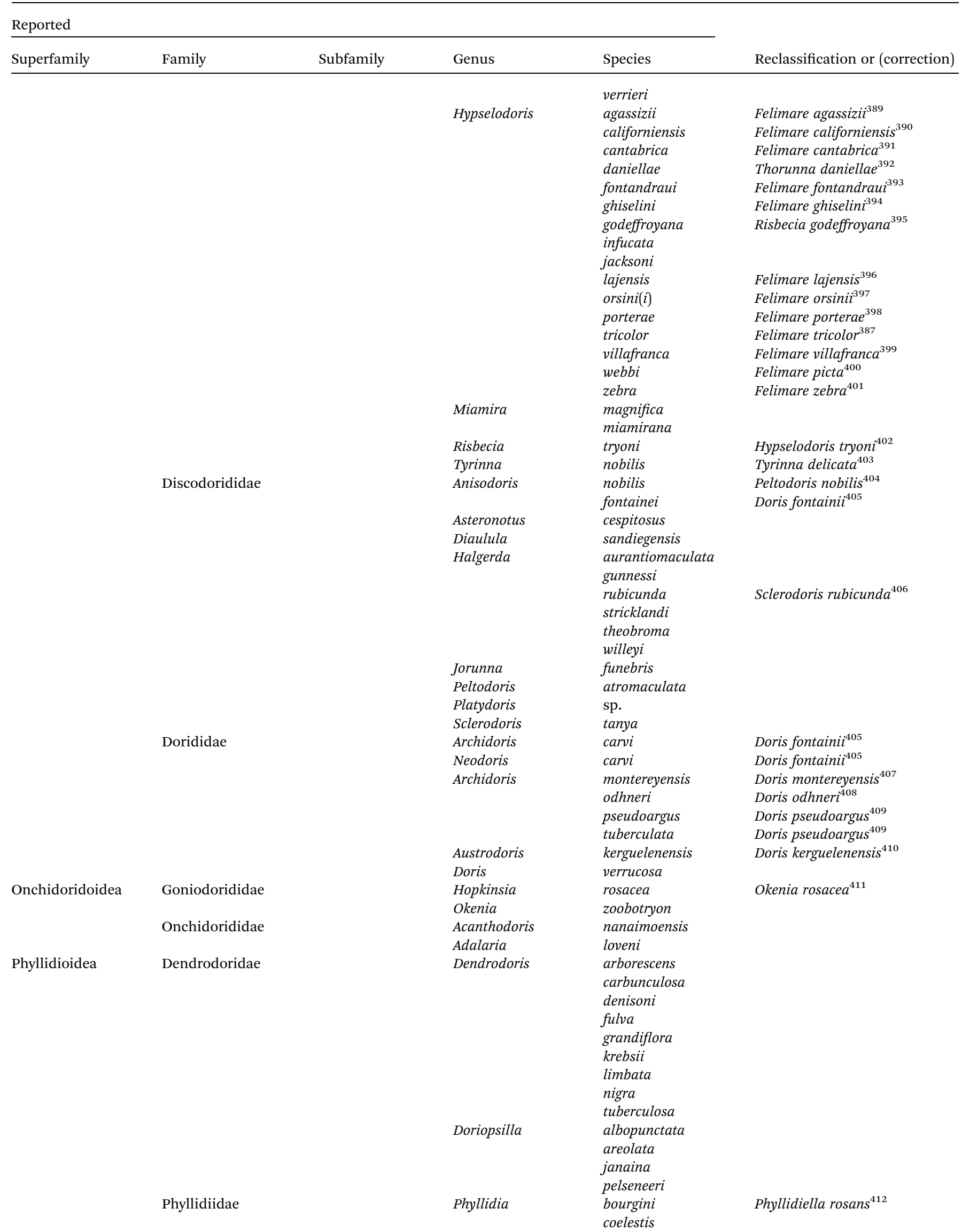


Table 1 (Contd.)

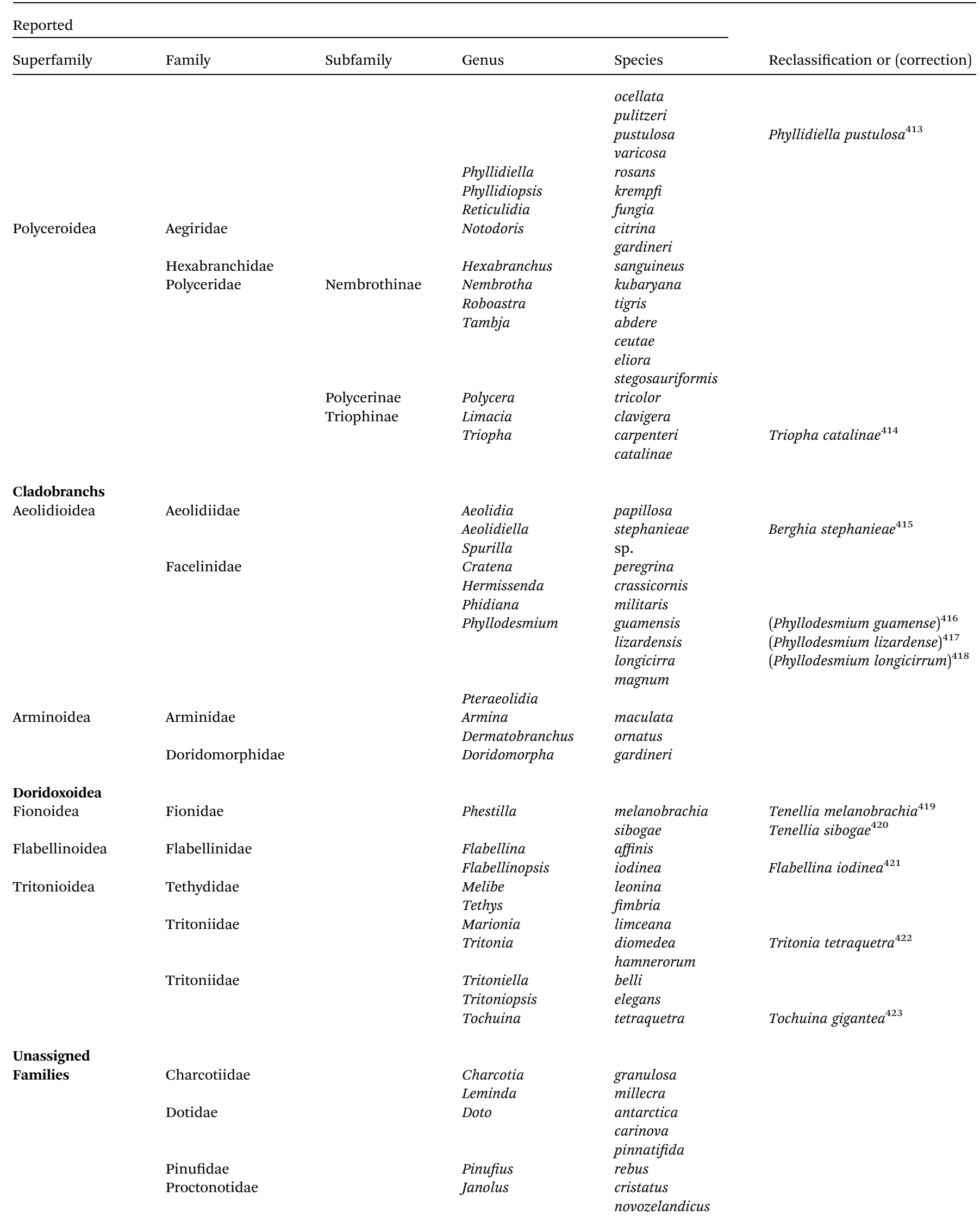




\section{Conflicts of interest}

There are no conflicts to declare.

\section{Acknowledgements}

We thank Tracey Bates, Rex Fairweather and Joanne Porter for the photographs provided for this review, Tracey Bates and Rex Fairweather for helpful discussions and the anonymous reviewers for their helpful suggestions which have improved this manuscript.

\section{References}

1 R. C. Anderson, Int. Zoo Yb., 1995, 34, 65-70, DOI: 10.1111/ j.1748-1090.1995.tb00659.x.

2 S. Gofas, Nudibranchia In MolluscaBase, 2017, 15 May, 2017, accessed through: World Register of Marine Species (WoRMS) at, http:/www.marinespecies.org/aphia.php? $\mathrm{p}=$ taxdetails\&id $=1762$.

3 B. E. Picton and C. C. Morrow, Nudibranchs of the British Isles, 1996, http://www.seaslug.org.uk/nudibranchs/ index.html, accessed 7 January, 2016.

4 B. F. Murphy and M. G. Hadfield, Comp. Biochem. Physiol., 1997, 118A, 727-735, DOI: 10.1016/S0300-9629(97)00014-5.

5 G.-P. Hu, J. Yuan, L. Sun, Z.-G. She, J.-H. Wu, X.-J. Lan, X. Zhu, Y.-C. Lin and S.-P. Chen, Mar. Drugs, 2011, 9, 514525, DOI: $10.3390 /$ md9040514.

6 D. J. Faulkner and M. T. Ghiselin, Mar. Ecol.: Prog. Ser., 1983, 13, 295-301, DOI: 10.3354/meps013295.

7 G. Cimino and M. T. Ghiselin, Chemoecology, 1999, 9, 187207, DOI: $10.1007 / \mathrm{s} 000490050052$.

8 M. Carbone, M. Gavagnin, M. Haber, Y.-W. Guo, A. Fontana, E. Manzo, G. Genta-Jouve, M. Tsoukatou, W. B. Rudman, G. Cimino, M. T. Ghiselin and E. Mollo, PLoS One, 2013, 8, e62075.

9 P. G. Greenwood, Toxicon, 2009, 54, 1065-1070, DOI: 10.1016/j.toxicon.2009.02.029.

10 H. Wägele and R. C. Willan, Zool. J. Linn. Soc., 2000, 130, 83181, DOI: 10.1111/j.1096-3642.2000.tb02196.x.

11 M. Schrödl, H. Wägele and R. C. Willan, Zool. Anz., 2001, 240, 83-97, DOI: 10.1078/0044-5231-00008.

12 P. Bouchet, J. Fryda, B. Hausdorf, W. Ponder, A. Valdés and A. Warén, Malacologia, 2005, 47, 261-263.

13 WoRMS, http://www.marinespecies.org/aphia.php? $\mathrm{p}=$ taxdetails\&id=1762, accessed 15 May, 2017.

14 J. A. Goodheart, A. L. Bazinet, A. G. Collins and M. P. Cummings, R. Soc. Open Sci., 2015, 2, 150196, DOI: 10.1098/rsos.150196.

15 J. Mahguib and A. Valdés, Polar Biol., 2015, 38, 1369-1377, DOI: 10.1007/s00300-015-1700-5.

16 A. W. W. van Wyk and M. T. Davies-Coleman, Tetrahedron, 2007, 63, 12179-12184.

17 M. J. Garson, Chem. Rev., 1993, 93, 1699-1733, DOI: 10.1021/cr00021a003.
18 D. J. Faulkner, T. F. Molinski, R. J. Anderson, E. J. Dumdei and E. Dilip de Silva, Comp. Biochem. Physiol., Part B: Biochem. Mol. Biol., 1990, 97, 233-240.

19 P. Karuso, Bioorg. Mar. Chem., 1987, 1, 31-60, DOI: 10.1007/ 978-3-642-72726-9_2.

20 P. Proksch, Biol. Unserer Zeit, 1991, 21, 26-30, DOI: 10.1002/ biuz.19910210110.

21 G. Cimino, A. Fontana and M. Gavagnin, Curr. Org. Chem., 1999, 3, 327-372.

22 P. Proksch, Toxicon, 1994, 32, 639-655, DOI: 10.1016/00410101(94)90334-4.

23 G. Cimino and G. Sodano, in Sponges Time Space, Proc. 4th Int. Porifera Congr, ed. R. W. M. Van Soest, T. M. G. Van Kempen and J.-C. Braekman, 1994, pp. 459-472.

24 M. Ishibashi, Y. Yamaguchi and Y. J. Hirano, in Biomaterials from Aquatic and Terrestrial Organisms, ed. M. Fingerman and R. Nagabhushanam, 2006, pp. 513-535.

25 G. Cimino, M. L. Ciavatta, A. Fontana and M. Gavagnin, in Bioactive Compounds from Natural Sources, ed. C. Tringali, 2001, pp. 577-637.

26 M. Gavagnin and A. Fontana, Curr. Org. Chem., 2000, 4, 1201-1248, DOI: 10.2174/1385272003375798.

27 R. J. Andersen, E. D. De Silva, E. J. Dumdei, P. T. Northcote, C. Pathirana and M. Tischler, in Recent Advances in Phytochemistry, Biochem. Mevalonic Acid Pathway Terpenoids, 1990, vol. 24, pp. 265-282.

28 M. J. Garson, J. S. Simpson, A. E. Flowers and E. J. Dumdei, Bioactive Natural Products (Part B), in Studies in Natural Products Chemistry, 2000, vol. 21, pp. 329-372.

29 M. J. Garson and J. S. Simpson, Nat. Prod. Rep., 2004, 21, 164-179, DOI: 10.1039/b302359c.

30 T. Grkovic, D. R. Appleton and B. R. Copp, Chem. N.Z., 2005, 69, 12-15.

31 M. J. Garson, Prog. Mol. Subcell. Biol., 2006, 43(Molluscs), 159-174.

32 M. J. Garson, Chem. Aust., 2004, 71, 16-18.

33 R. J. Andersen, K. Desjardine and K. Woods, Prog. Mol. Subcell. Biol., 2006, 43(Molluscs), 277-301.

34 T. Miyamoto, Prog. Mol. Subcell. Biol., 2006, 43(Molluscs), 199-214.

35 M. T. Davies-Coleman, Prog. Mol. Subcell. Biol., 2006, 43(Molluscs), 133-157.

36 (a) J. W. Blunt, B. R. Copp, R. A. Keyzers, M. H. G. Munro and M. R. Prinsep, Nat. Prod. Rep., 2017, 34, 235-294, DOI: 10.1039/C6NP00124F; (b) J. W. Blunt, B. R. Copp, R. A. Keyzers, M. H. G. Munro and M. R. Prinsep, Nat. Prod. Rep., 2016, 33, 382-431, DOI: 10.1039/C5NP00156K; (c) J. W. Blunt, B. R. Copp, R. A. Keyzers, M. H. G. Munro and M. R. Prinsep, Nat. Prod. Rep., 2015, 32, 116-211, DOI: 10.1039/C4NP00144C; (d) J. W. Blunt, B. R. Copp, R. A. Keyzers, M. H. G. Munro and M. R. Prinsep, Nat. Prod. Rep., 2014, 31, 160-258, DOI: 10.1039/c3np70117d; (e) J. W. Blunt, B. R. Copp, R. A. Keyzers, M. H. G. Munro and M. R. Prinsep, Nat. Prod. Rep., 2013, 30, 237-323, DOI: 10.1039/C2NP20112G; (f) J. W. Blunt, B. R. Copp, R. A. Keyzers, M. H. G. Munro and M. R. Prinsep, Nat. Prod. Rep., 2012, 29, 144-222, DOI: 10.1039/C2NP00090C. 
37 I. W. Mudianta, A. M. White, Suciati, P. L. Katavic, R. R. Krishnaraj, A. E. Winters, E. Mollo, K. L. Cheney and M. J. Garson, Pure Appl. Chem., 2014, 86, 995-1002, DOI: 10.1515/pac-2013-1111.

38 V. T. Dang, K. Benkendorff, T. Green and P. Speck, J. Virol., 2015, 89, 8114-8118, DOI: 10.1128/JVI.00287-15.

39 N. V. Zhukova, Mar. Drugs, 2014, 12, 4578-4592, DOI: 10.3390/md12084578.

40 K. Iken, C. Avila, M. L. Ciavatta, A. Fontana and G. Cimino, Tetrahedron Lett., 1998, 39, 5635-5638, DOI: 10.1016/S00404039(98)01095-8.

41 C. Avila, K. Iken, A. Fontana and G. Cimino, J. Exp. Mar. Biol. Ecol., 2000, 252, 27-44, DOI: 10.1016/S0022-0981(00) 00227-6.

42 MarinLit, The Royal Society of Chemistry, http:// pubs.rsc.org/marinlit/, accessed 29 June 2017.

43 E. Manzo, M. Carbone, E. Mollo, C. Irace, A. Di Pascale, Y. Li, M. L. Ciavatta, G. Cimino, Y.-W. Guo and M. Gavagnin, Org. Lett., 2011, 13, 1897-1899, DOI: 10.1021/ol200377w.

44 G. Nuzzo, M. L. Ciavatta, R. Kiss, V. Mathieu, H. Leclercqz, E. Manzo, G. Villani, E. Mollo, F. Lefranc, L. D'Souza, M. Gavagnin and G. Cimino, Mar. Drugs, 2012, 10, 17991811, DOI: $10.3390 / \mathrm{md} 10081799$.

45 A. Rudi, Z. Stein, S. Green, I. Goldberg, Y. Kashman, Y. Benayahu and M. Schleyer, Tetrahedron Lett., 1994, 35, 2589-2592, DOI: 10.1016/S0040-4039(00)77179-6.

46 S. W. Ayer and R. J. Andersen, Tetrahedron Lett., 1982, 23, 1039-1042, DOI: 10.1016/S0040-4039(00)87016-1.

47 M. Gavagnin, N. Ungur, E. Mollo, J. Templado and G. Cimino, Eur. J. Org. Chem., 2002, 1500-1504, DOI: 10.1002/1099-0690(200205)2002:9<1500::AID-

EJOC1500>3.0.CO;2-D.

48 J. Kubanek, D. J. Faulkner and R. J. Anderson, J. Chem. Ecol., 2000, 26, 377-389, DOI: 10.1023/A:1005405304862.

49 D. L. Burgoyne, E. J. Dumdei and R. J. Andersen, Tetrahedron, 1993, 49, 4503-4510, DOI: 10.1016/S00404020(01)81280-1.

50 J. E. Thompson, R. P. Walker, S. J. Wratten and D. J. Faulkner, Tetrahedron, 1982, 38, 1865-1873, DOI: 10.1016/0040-4020(82)80035-5.

51 J. Hellou, R. J. Anderson and J. E. Thompson, Tetrahedron, 1982, 38, 1875-1879, DOI: 10.1016/0040-4020(82)80036-7.

52 K. Gustafson, R. J. Andersen, C. H. He and J. Clardy, Tetrahedron Lett., 1985, 26, 2521-2524, DOI: 10.1016/ S0040-4039(00)98826-9.

53 M. Tischler, R. J. Andersen, M. I. Choudhary and J. Clardy, J. Org. Chem., 1991, 56, 42-47, DOI: 10.1021/jo00001a010.

54 J. Daoust, A. Fontana, C. E. Merchant, N. J. de Voogd, B. O. Patrick, T. J. Kieffer and R. J. Andersen, Org. Lett., 2010, 12, 3208-3211, DOI: 10.1021/ol101151f.

55 J. Hellou, R. J. Andersen, S. Rafii, E. Arnold and J. Clardy, Tetrahedron Lett., 1981, 22, 4173-4176, DOI: 10.1016/ S0040-4039(01)82096-7.

56 M. Tischler and R. J. Andersen, Tetrahedron Lett., 1989, 30, 5717-5720, DOI: 10.1016/S0040-4039(00)76179-X.
57 E. J. Dumdei, J. Kubanek, J. E. Coleman, J. Pika, R. J. Anderson, J. R. Steiner and J. Clardy, Can. J. Chem., 1997, 75, 773-789, DOI: 10.1139/v97-094.

58 J. Kubanek, E. I. Graziani and R. J. Andersen, J. Org. Chem., 1997, 62, 7239-7246, DOI: 10.1021/JO970695V.

59 A. Fontana, M. Gavagnin, E. Mollo, E. Trivellone, J. Ortea and G. Cimino, Comp. Biochem. Physiol., Part B: Biochem. Mol. Biol., 1995, 111, 283-290, DOI: 10.1016/0305-0491(94) 00250-X.

60 A. M. White, A. S. Dewi, K. L. Cheney, A. E. Winters, J. T. Blanchfield and M. J. Garson, Nat. Prod. Commun., 2016, 11, 921-924.

61 D. E. de Silva and P. J. Scheuer, Heterocycles, 1982, 17, 167170, DOI: 10.3987/S-1982-01-0167.

62 R. Kazlauskas, Rymantas, P. T. Murphy, R. J. Wells, K. Noack, W. E. Oberhaensli and P. Schoenholzer, Aust. J. Chem., 1979, 32, 867-880, DOI: org/10.1071/CH9790867.

63 T. Grkovic, D. R. Appleton and B. R. Copp, Chem. N. Z., 2005, 69, 12-15.

64 R. Kazlauskas, P. T. Murphy, R. J. Quinn and R. J. Wells, Aust. J. Chem., 1976, 29, 2533-2539, DOI: 10.1071/ CH9762533.

65 M. B. Ksebati and F. J. Schmitz, J. Org. Chem., 1987, 52, 3766-3773, DOI: 10.1021/jo00226a008.

66 E. Mollo, M. Gavagnin, M. Carbone, Y.-W. Guo and G. Cimino, Chemoecology, 2005, 15, 31-36, DOI: 10.1007/ s00049-005-0289-5.

67 M. B. Ksebati and F. J. Schmitz, J. Nat. Prod., 1988, 51, 857861, DOI: 10.1021/np50059a007.

68 G. Cimino, S. De Stefano, A. Guerriero and L. Minale, Tetrahedron Lett., 1975, 1425-1428, DOI: 10.1016/S00404039(00)72159-9.

69 R. Kazlauskas, P. T. Murphy, R. J. Wells, J. J. Daly and P. Schoenholzer, Tetrahedron Lett., 1978, 4951-4954, DOI: 10.1016/S0040-4039(01)85779-8.

70 G. M. Cameron, B. L. Stapleton, S. M. Simonsen, D. J. Brecknell and M. J. Garson, Tetrahedron, 2000, 56, 5247-5252, DOI: 10.1016/S0040-4020(00)00434-8.

71 C. Charles, J. C. Braekman, D. Daloze, B. Tursch, J. P. Declercq, G. Germain and M. Van Meerssche, Bull. Soc. Chim. Belg., 1978, 87, 481-486.

72 A. Fontana, C. Avila, E. Martinez, J. Ortea, E. Trivellone and G. Cimino, J. Chem. Ecol., 1993, 19, 339-356, DOI: 10.1007/ BF00993700.

73 J. E. Hochlowski and D. J. Faulkner, Tetrahedron Lett., 1981, 22, 271-274, DOI: 10.1016/0040-4039(81)80073-1.

74 G. R. Schulte and P. J. Scheuer, Tetrahedron, 1982, 38, 18571863, DOI: 10.1016/0040-4020(82)80034-3.

75 J. E. Hochlowski, D. J. Faulkner, L. S. Bass and J. Clardy, J. Org. Chem., 1983, 48, 1738-1740, DOI: 10.1021/ jo00158a030.

76 J. E. Hochlowski, D. J. Faulkner, G. K. Matsumoto and J. Clardy, J. Org. Chem., 1983, 48, 1141-1142, DOI: 10.1021/jo00155a055.

77 R. K. Okuda and P. J. Scheuer, Experientia, 1985, 41, 13551356. 
78 B. Carte, M. R. Kernan, E. B. Barrabee, D. J. Faulkner, G. K. Matsumoto and J. Clardy, J. Org. Chem., 1986, 51, 3528-3532, DOI: 10.1021/jo00368a025.

79 B. Terem and P. J. Scheuer, Tetrahedron, 1986, 42, 44094412, DOI: 10.1016/S0040-4020(01)87279-3.

80 T. F. Molinski and D. J. Faulkner, J. Org. Chem., 1986, 51, 2601-2603, DOI: 10.1021/jo00363a040.

81 T. F. Molinski, D. J. Faulkner, C. H. He, G. D. Van Duyne and J. Clardy, J. Org. Chem., 1986, 51, 4564-4567, DOI: 10.1021/jo00374a014.

82 Y. Kakou, P. Crews and G. J. Bakus, J. Nat. Prod., 1987, 50, 482-484, DOI: 10.1021/np50051a023.

83 D. G. Corley, R. Herb, R. E. Moore, P. J. Scheuer and V. J. Paul, J. Org. Chem., 1988, 53, 3644-3646, DOI: 10.1021/jo00250a053.

84 M. R. Kernan, E. B. Barrabee and D. J. Faulkner, Comp. Biochem. Physiol., Part B: Biochem. Mol. Biol., 1988, 89B, 275-278, DOI: 10.1016/0305-0491(88)90223-4.

85 S. C. Bobzin and D. J. Faulkner, J. Org. Chem., 1989, 54, 3902-3907, DOI: 10.1021/jo00277a029.

86 E. J. Dumdei, E. D. De Silva, R. J. Andersen, M. I. Choudhary and J. Clardy, J. Am. Chem. Soc., 1989, 111, 2712-2713, DOI: 10.1021/ja00189a055.

87 G. Cimino, A. Crispino, M. Gavagnin and G. Sodano, J. Nat. Prod., 1990, 53, 102-106, DOI: 10.1021/np50067a013.

88 E. Dilip de Silva, S. A. Morris, S. Miao, E. Dumdei and R. J. Andersen, J. Nat. Prod., 1991, 54, 993-997, DOI: 10.1021/np50076a011.

89 S. A. Morris, E. Dilip de Silva and R. J. Andersen, Can. J. Chem., 1991, 69, 768-771, DOI: 10.1139/v91-114.

90 M. Gavagnin, R. R. Vardaro, C. Avila, G. Cimino and J. Ortea, J. Nat. Prod., 1992, 55, 368-371, DOI: 10.1021/ np50081a014.

91 K. Sakamoto, T. Miyamoto, H. Amano, R. Higuchi, T. Komori and T. Sasaki, Tennen Yuki Kagobutsu Toronkai Koen Yoshishu, 1992, 34, 455-462.

92 T. Miyamoto, K. Sakamoto, H. Amano, R. Higuchi, T. Komori and T. Sasaki, Tetrahedron Lett., 1992, 33, 5811-5814, DOI: 10.1016/0040-4039(92)89038-E.

93 R. Puliti, M. Gavagnin, G. Cimino, C. A. Mattia and L. Mazzarella, Acta Crystallogr., Sect. C: Struct. Chem., 1992, C48, 2145-2147, DOI: 10.1107/S0108270192003196.

94 J. Pika and D. J. Faulkner, Tetrahedron, 1995, 51, 8189-8198, DOI: 10.1016/0040-4020(95)00440-J.

95 T. Miyamoto, K. Sakamoto, K. Arao, T. Komori, R. Higuchi and T. Sasaki, Tetrahedron, 1996, 52, 8187-8198, DOI: 10.1016/0040-4020(96)00388-2.

96 K. McPhail and M. T. Davies-Coleman, Tetrahedron, 1997, 53, 4655-4660, DOI: 10.1016/S0040-4020(97)00198-1.

97 T. Miyamoto, K. Sakamoto, H. Amano, Y. Arakawa, Y. Nagarekawa, T. Komori, R. Higuchi and T. Sasaki, Tetrahedron, 1999, 55, 9133-9142, DOI: 10.1016/S00404020(99)00477-9.

98 P. Karuso and P. J. Scheuer, Molecules, 2003, 8, 1-6, DOI: 10.3390/70100001-rev.

99 K. W. Yong, A. A. Salim and M. J. Garson, Tetrahedron, 2008, 64, 6733-6738, DOI: 10.1016/j.tet.2008.05.008.
100 M. H. Uddin, M. Otsuka, T. Muroi, A. Ono, N. Hanif, S. Matsuda, T. Higa and J. Tanaka, Chem. Pharm. Bull., 2009, 57, 885-887, DOI: 10.1248/cpb.57.885.

101 M. Agena, C. Tanaka, N. Hanif, M. Yasumoto-Hirose and J. Tanaka, Tetrahedron, 2009, 65, 1495-1499, DOI: 10.1016/j.tet.2008.11.101.

102 Suciati, L. K. Lambert and M. J. Garson, Aust. J. Chem., 2011, 64, 757-765, DOI: 10.1071/CH11036.

103 P. L. Katavic, P. Jumaryatno, J. N. A. Hooper, J. T. Blanchfield and M. J. Garson, Aust. J. Chem., 2012, 65, 531-538, DOI: 10.1071/CH12010.

104 P. L. Katavic, P. Jumaryatno, J. N. A. Hooper, J. T. Blanchfield and M. J. Garson, Aust. J. Chem., 2013, 66, 1461, DOI: 10.1071/CH12010_NC.

105 K. L. Cheney, A. White, I. W. Mudianta, A. E. Winters, M. Quezada, R. J. Capon, E. Mollo and M. J. Garson, PLoS One, 2016, 11, e0145134, DOI: 10.1371/ journal.pone.0145134.

106 G. Schulte, P. J. Scheuer and O. J. McConnell, Helv. Chim. Acta, 1980, 63, 2159-2167, DOI: 10.1002/hlca.19800630805.

107 C. W. Jefford, G. Bernardinelli, J. Tanaka and T. Higa, Tetrahedron Lett., 1996, 37, 159-162, DOI: 10.1016/00404039(95)02113-2.

108 A. K. Ghosh and Y. Wang, J. Am. Chem. Soc., 2000, 122, 11027-11028, DOI: 10.1021/ja0027416.

109 A. Gollner and J. Mulzer, Org. Lett., 2008, 10, 4701-4704, DOI: $10.1021 /$ ol802075v.

110 Y. Kashman, A. Groweiss, R. Lidor, D. Blasberger and S. Carmely, Tetrahedron, 1985, 41, 1905-1914, DOI: 10.1016/S0040-4020(01)96553-6.

111 M. C. A. Ramirez, D. E. Williams, J. R. Gubiani, L. L. L. Parra, M. F. C. Santos, D. D. Ferreira, J. T. Mesquita, A. G. Tempone, A. G. Ferreira, V. Padula, E. Hajdu, R. J. Andersen and R. G. S. Berlinck, J. Nat. Prod., 2017, 80, 720-725, DOI: 10.1021/ acs.jnatprod.6b01160.

112 J. M. Wojnar, K. O. Dowle and P. T. Northcote, J. Nat. Prod., 2014, 77, 2288-2295, DOI: 10.1021/np500549g.

113 T. F. Molinski and D. J. Faulkner, J. Org. Chem., 1987, 52, 296-298, DOI: 10.1021/jo00378a031.

114 Y. Hirayama, P. L. Katavic, A. M. White, G. K. Pierens, L. K. Lambert, A. E. Winters, H. Kigoshi, M. Kita and M. J. Garson, Aust. J. Chem., 2016, 69, 136-144, DOI: 10.1071/CH15203.

115 E. Manzo, M. Gavagnin, M. J. Somerville, S.-C. Mao, M. L. Ciavatta, E. Mollo, P. J. Schupp, M. J. Garson, Y.-W. Guo and G. Cimino, J. Chem. Ecol., 2007, 33, 23252336, DOI: 10.1007/s10886-007-9387-x.

116 D. Mebs, J. Chem. Ecol., 1985, 11, 713-716, DOI: 10.1007/ BF00988300.

117 M. J. Somerville, E. Mollo, G. Cimino, W. Rungprom and M. J. Garson, J. Nat. Prod., 2006, 69, 1086-1088, DOI: 10.1021/np060002i.

118 M. J. Somerville, E. Mollo, G. Cimino, W. Rungprom and M. J. Garson, J. Nat. Prod., 2007, 70, 1836, DOI: 10.1021/ np070553o. 
119 K. W. L. Yong, I. W. Mudianta, K. L. Cheney, E. Mollo, J. Blanchfield and M. J. Garson, J. Nat. Prod., 2015, 78, 421-430, DOI: 10.1021/np500797b.

120 A. Fontana, E. Mollo, J. Ortea, M. Gavagnin and G. Cimino, J. Nat. Prod., 2000, 63, 527-530, DOI: 10.1021/np990506z.

121 G. Cimino, S. De Rosa, S. De Stefano and G. Sodano, Comp. Biochem. Physiol., Part B: Biochem. Mol. Biol., 1982, 73B, 471-474, DOI: 10.1016/0305-0491(82)90061-X.

122 S. D. Rogers and V. J. Paul, Mar. Ecol.: Prog. Ser., 1991, 77, 221-232, DOI: 10.3354/meps077221.

123 C. Avila and V. J. Paul, Mar. Ecol.: Prog. Ser., 1997, 150, 171180, DOI: $10.3354 /$ meps150171.

124 A. Fontana, P. Cavaliere, N. Ungur, L. D'Souza, P. S. Parameswaram and G. Cimino, J. Nat. Prod., 1999, 62, 1367-1370, DOI: 10.1021/np9900932.

125 M. Gavagnin, E. Mollo, T. Docimo, Y.-W. Guo and G. Cimino, J. Nat. Prod., 2004, 67, 2104-2107, DOI: 10.1021/np040087s.

126 I. W. Mudianta, A. M. White and M. J. Garson, Nat. Prod. Commun., 2015, 10, 865-868.

127 A. M. White, G. K. Pierens, L. C. Forster, A. E. Winters, K. L. Cheney and M. J. Garson, J. Nat. Prod., 2016, 79, 477-483, DOI: 10.1021/acs.jnatprod.5b00866.

128 L. C. Forster, A. E. Winters, K. L. Cheney, P. Dewapriya, R. J. Capon and M. J. Garson, J. Nat. Prod., 2017, 80, 670675, DOI: 10.1021/acs.jnatprod.6b00936.

129 J. E. Hochlowski, R. P. Walker, C. Ireland and D. J. Faulkner, J. Org. Chem., 1982, 47, 88-91, DOI: 10.1021/jo00340a018.

130 S. H. Grode and J. H. Cardellina II, J. Nat. Prod., 1984, 47, 76-83, DOI: 10.1021/np50031a009.

131 J. C. Garcia-Gomez, G. Cimino and A. Medina, Mar. Biol., 1990, 106, 245-250.

132 C. Avila, G. Cimino, A. Fontana, M. Gavagnin, J. Ortea and E. Trivellone, J. Chem. Ecol., 1991, 17, 625-636, DOI: 10.1007/BF00982131.

133 G. Cimino, A. Fontana, F. Gimenez, A. Marin, E. Mollo, E. Trivellone and E. Zubia, Experientia, 1993, 49, 582-586.

134 A. Fontana, E. Trivellone, E. Mollo, G. Cimino, C. Avila, E. Martinez and J. Ortea, J. Nat. Prod., 1994, 57, 510-513, DOI: $10.1021 / \mathrm{np50106a011.}$

135 M. Haber, S. Cerfeda, M. Carbone, G. Calado, H. Gaspar, R. Neves, V. Maharajan, G. Cimino, M. Gavagnin, M. T. Ghiselin and E. Mollo, Biol. Bull., 2010, 218, 181188, DOI: 10.1086/BBLv218n2p181.

136 J. F. Cruz, H. Gaspar and G. Calado, Chemoecology, 2012, 22, 47-53, DOI: 10.1007/s00049-011-0097-z.

137 F. R. Pereira, R. G. S. Berlinck, E. Rodrigues Filho, K. Veloso, A. G. Ferreira and V. Padula, Quim. Nova, 2012, 35, 2194-2201, DOI: 10.1590/S0100-40422012001100018.

138 G. Cimino, S. De Stefano, L. Minale and E. Trivellone, Tetrahedron Lett., 1975, 3727-3730, DOI: 10.1016/S00404039(00)91320-0.

139 I. W. Mudianta, V. L. Challinor, A. E. Winters, K. L. Cheney, J. J. De Voss and M. J. Garson, Beilstein J. Org. Chem., 2013, 9, 2925-2933, DOI: 10.3762/bjoc.9.329.
140 A. S. Dewi, K. L. Cheney, H. H. Urquhart, J. T. Blanchfield and M. J. Garson, Mar. Drugs, 2016, 14, 198, DOI: 10.3390/md14110198.

141 S. J. Fahey and M. J. Garson, J. Chem. Ecol., 2002, 28, 17731785.

142 G. Guella, I. Mancini, A. Guerriero and F. Pietra, Helv. Chim. Acta, 1985, 68, 1276-1282, DOI: 10.1002/hlca.19850680523.

143 A. Fontana, C. Muniain and G. Cimino, J. Nat. Prod., 1998, 61, 1027-1029, DOI: 10.1021/NP980073K.

144 F. A. Fuhrman, G. J. Fuhrman, Y. H. Kim, L. A. Pavelka and H. S. Mosher, Science, 1980, 207, 193-195, DOI: 10.1126/ science.7350655.

145 S. J. Fahey and A. R. Carroll, J. Chem. Ecol., 2007, 33, 12261234, DOI: 10.1007/s10886-007-9288-z.

146 M. Gavagnin, N. Ungur, F. Castelluccio, C. Muniain and G. Cimino, J. Nat. Prod., 1999, 62, 269-274, DOI: 10.1021/ NP980344R.

147 E. Zubia, M. Gavagnin, A. Crispino, E. Martinez, J. Ortea and G. Cimino, Experientia, 1993, 49, 268-271.

148 N. Ungur, M. Gavagnin, E. Mollo and G. Cimino, Tetrahedron: Asymmetry, 1999, 10, 1635-1636, DOI: 10.1016/S0957-4166(99)00160-3.

149 J. Ren, P. Zhao, X. Xiao, T. Chen and B.-B. Zeng, Synthesis, 2016, 48, 4161-4166, DOI: 10.1055/s-0035-1561493.

150 Y. H. Kim, R. J. Nachman, L. Pavelka, H. S. Mosher, F. A. Fuhrman and G. J. Fuhrman, J. Nat. Prod., 1981, 44, 206-214, DOI: 10.1021/np50014a011.

151 R. J. Quinn, R. P. Gregson, A. F. Cook and R. T. Bartlett, Tetrahedron Lett., 1980, 21, 567-568, DOI: org/10.1016/ S0040-4039(01)85558-1.

152 K. Gustafson and R. J. Andersen, Tetrahedron, 1985, 41, 1101-1108, DOI: 10.1016/S0040-4020(01)96478-6.

153 M. D. Unson, C. B. Rose, D. J. Faulkner, L. S. Brinen, J. R. Steiner and J. Clardy, J. Org. Chem., 1993, 58, 63366343, DOI: 10.1021/jo00075a029.

154 E. Cherbuliez and K. Bernhard, Helv. Chim. Acta, 1932, 15, 978-980, DOI: 10.1002/hlca.193201501106.

155 F. A. Fuhrman, G. J. Fuhrman, R. J. Nachman and H. S. Mosher, Science, 1981, 212, 557-558, DOI: 10.1126/ science.7209552.

156 R. P. Walker and D. J. Faulkner, J. Org. Chem., 1981, 46, 1475-1478, DOI: 10.1021/jo00320a046.

157 R. P. de Jesus and D. J. Faulkner, J. Nat. Prod., 2003, 66, 671674, DOI: 10.1021/np020542p.

158 D. E. Williams, S. W. Ayer and R. J. Anderson, Can. J. Chem., 1986, 64, 1527-1529, DOI: 10.1139/v86-250.

159 J. Kubanek and R. J. Anderson, J. Nat. Prod., 1999, 62, 777779, DOI: $10.1021 /$ NP9804839.

160 K. V. Reddy, R. Mohanrajd, K. N. Murthy, C. Ramesh and P. Karthick, J. Coastal Life Med., 2015, 3, 582-584, DOI: 10.12980/JCLM.3.201514J65.

161 N. K. Gulavita, P. J. Scheuer and E. D. de Silva, Bioact. Compd. Mar. Org. Indo-U. S. Symp., ed. M. F. Thompson, R. Sarojini and R. Nagabhushanam, 1991, pp. 229-233.

162 W.-F. He, Y. Li, M.-T. Feng, M. Gavagnin, E. Mollo, S.-H. Mao and Y.-W. Guo, Fitoterapia, 2014, 96, 109-114, DOI: 10.1016/j.fitote.2014.04.011. 
163 R.-Y. Huang, W.-T. Chen, T. Kurtan, A. Mandi, J. Ding, J. Li, X.-W. Li and Y.-W. Guo, Future Med. Chem., 2016, 8, 17-27, DOI: $10.4155 /$ fmc.15.169.

164 A. Fontana, P. Cavaliere, S. Wahidulla, C. G. Naik and G. Cimino, Tetrahedron, 2000, 56, 7305-7308, DOI: 10.1016/S0040-4020(00)00629-3.

165 K. Charupant, K. Suwanborirux, S. Amnuoypol, E. Saito, A. Kubo and N. Saito, Chem. Pharm. Bull., 2007, 55, 81-86, DOI: $10.1248 / \mathrm{cpb} .55 .81$.

166 A. Kubo, Y. Kitahara and S. Nakahara, Chem. Pharm. Bull., 1989, 37, 1384-1386, DOI: 10.1248/cpb.37.1384.

167 C. Cuevas, M. Perez, A. Francesch, C. Fernandez, J. L. Chicharro, P. Gallego, M. Zarzuelo, F. De la Calle and I. Manzanares, PCT Int. Appl., WO 2000069862 A2 20001123, 2000.

168 B. J. Petek and R. L. Jones, Molecules, 2014, 19, 1232812335, DOI: 10.3390/molecules190812328.

169 D. Castiello, G. Cimino, S. De Rosa, S. De Stefano, G. Izzo and G. Sodano, Colloq. Int. C. N. R. S., 1979, 291, 413416.

170 D. Castiello, G. Cimino, S. De Rosa, S. De Stefano and G. Sodano, Tetrahedron Lett., 1980, 21, 5047-5050, DOI: 10.1016/S0040-4039(00)71129-4.

171 M. L. Ciavatta, G. Nuzzo, K. Takada, V. Mathieu, R. Kiss, G. Villani and M. Gavagnin, J. Nat. Prod., 2014, 77, 16781684, DOI: 10.1021/np500298h.

172 P. J. Krug, K. G. Boyd and D. J. Faulkner, Tetrahedron, 1995, 51, 11063-11074, DOI: 10.1016/0040-4020(95)00679-3.

173 E. I. Graziani, R. J. Andersen, P. J. Krug and D. J. Faulkner, Tetrahedron, 1996, 52, 6869-6878, DOI: 10.1016/00404020(96)00327-4.

174 N. Ungur, M. Gavagnin, A. Fontana and G. Cimino, Tetrahedron: Asymmetry, 1999, 10, 1263-1273, DOI: 10.1016/S0957-4166(99)00119-6.

175 R. J. Andersen and F. W. Sum, Tetrahedron Lett., 1980, 21, 797-800, DOI: 10.1016/S0040-4039(00)71508-5.

176 K. Gustafson, R. J. Andersen, M. H. M. Chen, J. Clardy and J. E. Hochlowski, Tetrahedron Lett., 1984, 25, 11-14, DOI: 10.1016/S0040-4039(01)91135-9.

177 A. Soriente, G. Sodano, K. C. Reed and C. Todd, Nat. Prod. Lett., 1993, 3, 31-35, DOI: 10.1080/10575639308043834.

178 G. Cimino, A. Crispino, M. Gavagnin, E. Trivellone, E. Zubia, E. Martinez and J. Ortea, J. Nat. Prod., 1993, 56, 1642-1646, DOI: 10.1021/np50099a033.

179 N. Ungur, M. Gavagnin and G. Cimino, Tetrahedron Lett., 1996, 37, 3549-3552, DOI: 10.1016/0040-4039(96)00609-0.

180 R. M. Young and B. J. Baker, Planta Med., 2016, 81, S1-S381.

181 A. Cutignano, W. Zhang, C. Avila, G. Cimino and A. Fontana, Eur. J. Org. Chem., 2011, 5383-5389, S5383, DOI: $10.1002 /$ ejoc.201100552.

182 M. T. Davies-Coleman and D. J. Faulkner, Tetrahedron, 1991, 47, 9743-9750, DOI: 10.1016/S0040-4020(01) 80714-6.

183 M. Gavagnin, A. De Napoli, G. Cimino, K. Iken, C. Avila and F. J. Garcia, Tetrahedron: Asymmetry, 1999, 10, 2647-2650, DOI: 10.1016/S0957-4166(99)00273-6.
184 J. A. Maschek, E. Mevers, T. Diyabalanage, L. Chen, Y. Ren, J. B. McClintock, C. D. Amsler, J. Wu and B. J. Baker, Tetrahedron, 2012, 68, 9095-9104, DOI: 10.1016/ j.tet.2012.08.045.

185 M. Gavagnin, E. Trivellone, F. Castelluccio, G. Cimino and R. Cattaneo-Vietti, Tetrahedron Lett., 1995, 36, 7319-7322, DOI: 10.1016/0040-4039(95)01476-X.

186 M. Gavagnin, M. Carbone, E. Mollo and G. Cimino, Tetrahedron, 2003, 59, 5579-5583, DOI: 10.1016/S00404020(03)00775-0.

187 T. Diyabalanage, K. B. Iken, J. B. McClintock, C. D. Amsler and B. J. Baker, J. Nat. Prod., 2010, 73, 416-421, DOI: $10.1021 / \mathrm{np} 900617 \mathrm{~m}$.

188 M. Gavagnin, A. De Napoli, F. Castelluccio and G. Cimino, Tetrahedron Lett., 1999, 40, 8471-8475, DOI: 10.1016/S00404039(99)01777-3.

189 L. Núñez-Pons and C. Avila, Nat. Prod. Rep., 2015, 32, 11141130, DOI: 10.1039/C4NP00150H.

190 M. Gavagnin, M. Carbone, E. Mollo and G. Cimino, Tetrahedron Lett., 2003, 44, 1495-1498, DOI: 10.1016/ S0040-4039(02)02849-6.

191 K. Iken, C. Avila, A. Fontana and M. Gavagnin, Mar. Biol., 2002, 141, 101-109, DOI: 10.1007/s00227-002-0816-7.

192 M. Gavagnin, A. Fontana, M. L. Ciavatta and G. Cimino, Ital. J. Zool., 2000, 67(Suppl.), 101-109, DOI: 10.1080/ 11250000009356363.

193 G. Cimino, M. Gavagnin, G. Sodano, R. Puliti, C. A. Mattia and L. Mazzarella, Tetrahedron, 1988, 44, 2301-2310, DOI: 10.1016/S0040-4020(01)81739-7.

194 M. Gavagnin, N. Ungur, F. Castelluccio and G. Cimino, Tetrahedron, 1997, 53, 1491-1504, DOI: 10.1016/S00404020(96)01083-6.

195 L. De Petrocellis, V. Di Marzo, B. Arca, M. Gavagnin, R. Minei and G. Cimino, Comp. Biochem. Physiol., C: Comp. Pharmacol., 1991, 100C, 603-607.

196 C. Avila, M. Ballesteros, G. Cimino, A. Crispino, M. Gavagnin and G. Sodano, Comp. Biochem. Physiol., Part B: Biochem. Mol. Biol., 1990, 97B, 363-368, DOI: 10.1016/ 0305-0491(90)90294-4.

197 G. Cimino, A. Crispino, S. De Stefano, M. Gavagnin and G. Sodano, Experientia, 1986, 42, 1301-1302.

198 M. Porcelli, G. Cacciapuoti, A. Oliva and V. Zappia, J. Chromatogr., 1988, 440, 151-155, DOI: 10.1016/S00219673(00)94519-9.

199 A. C. Granato, R. G. S. Berlinck, A. Magalhaes, A. B. Schefer, A. G. Ferreira, B. De Sanctis, J. C. De Freitas, E. Hajdu and A. E. Migotto, Quim. Nova, 2000, 23, 594-599, DOI: 10.1590/ S0100-40422000000500005.

200 M. Porcelli, G. Cacciapuoti, G. Cimino, M. Gavagnin, G. Sodano and V. Zappia, Biochem. J., 1989, 263, 635-640, DOI: $10.1042 /$ bj2630635.

201 S. W. Ayer, J. Hellou, M. Tischler and R. J. Andersen, Tetrahedron Lett., 1984, 25, 141-144, DOI: 10.1016/S00404039(00)99824-1.

202 S. W. Ayer, R. J. Andersen, C. H. He and J. Clardy, J. Org. Chem., 1984, 49, 2653-2654, DOI: 10.1021/jo00188a036. 
203 E. I. Graziani and R. J. Andersen, J. Am. Chem. Soc., 1996, 118, 4701-4702, DOI: 10.1021/JA9539305.

204 E. I. Graziani, T. M. Allen and R. J. Andersen, Tetrahedron Lett., 1995, 36, 1763-1766, DOI: 10.1016/0040-4039(95) 00118-V.

205 H. H. Strain, Biol. Bull., 1949, 97, 206-209, DOI: 10.2307/ 1538298.

206 J. W. McBeth, Comp. Biochem. Physiol., Part B: Biochem. Mol. Biol., 1972, 41, 69-77, DOI: 10.1016/0305-0491(72)90008-9.

207 WoRMS, http://www.marinespecies.org/aphia.php? $\mathrm{p}=$ taxdetails\&id $=851581$, accessed 23 May 2017.

208 G. Cimino, S. De Rosa, S. De Stefano, G. Sodano and G. Villani, Science, 1983, 219, 1237-1238, DOI: 10.1126/ science.219.4589.1237.

209 G. Cimino, S. De Rosa, S. De Stefano and G. Sodano, Experientia, 1985, 41, 1335-1336.

210 G. Cimino, G. Sodano and A. Spinelli, J. Nat. Prod., 1988, 51, 1010-1011, DOI: 10.1021/np50059a039.

211 G. Cimino, S. De Rosa, S. De Stefano and G. Sodano, Tetrahedron Lett., 1981, 22, 1271-1272, DOI: 10.1016/ S0040-4039(01)90293-X.

212 G. Cimino, S. De Rosa, S. De Stefano, R. Morrone and G. Sodano, Tetrahedron, 1985, 41, 1093-1100, DOI: 10.1016/S0040-4020(01)96477-4.

213 A. Fontana, M. L. Ciavatta, T. Miyamoto, A. Spinella and G. Cimino, Tetrahedron, 1999, 55, 5937-5946, DOI: 10.1016/S0040-4020(99)00256-2.

214 Y. Sakio, Y. J. Hirano, M. Hayashi, K. Komiyama and M. Ishibashi, J. Nat. Prod., 2001, 64, 726-731, DOI: 10.1021/np000639g.

215 R. K. Okuda, P. J. Scheuer, J. E. Hochlowski, R. P. Walker and D. J. Faulkner, J. Org. Chem., 1983, 48, 1866-1869, DOI: $10.1021 /$ jo00159a014.

216 M. Gavagnin, E. Mollo, G. Calado, S. Fahey, M. Ghiselin, J. Ortea and G. Cimino, Chemoecology, 2001, 11, 131-136, DOI: $10.1007 /$ PL00001843.

217 C. Avila, G. Cimino, A. Crispino and A. Spinella, Experientia, 1991, 47, 306-310, DOI: 10.1007/BF01958169.

218 A. Fontana, G. Villani and G. Cimino, Tetrahedron Lett., 2000, 41, 2429-2433, DOI: 10.1016/S0040-4039(00)00135-0.

219 N. V. Zhukova and M. G. Eliseikina, Mar. Biol., 2012, 159, 1783-1794, DOI: 10.1007/s00227-012-1969-7.

220 Y. Asakawa and T. Aratani, Bull. Soc. Chim. Fr., 1976, 9-10, 1469-1470.

221 H. Gaspar, M. Gavagnin, G. Calado, F. Castelluccio, E. Mollo and G. Cimino, Tetrahedron, 2005, 61, 1103211037, DOI: 10.1016/j.tet.2005.08.096.

222 A. Fontana, A. Tramice, A. Cutignano, G. d'Ippolito, M. Gavagnin and G. Cimino, J. Org. Chem., 2003, 68, 2405-2409, DOI: 10.1021/jo026131v.

223 M. Gavagnin, E. Mollo, F. Castelluccio, M. T. Ghiselin, G. Calado and G. Cimino, Tetrahedron, 2001, 57, 89138916, DOI: 10.1016/S0040-4020(01)00876-6.

224 A. Spinella, L. A. Alvarez, C. Avila and G. Cimino, Tetrahedron Lett., 1994, 35, 8665-8668, DOI: 10.1016/ S0040-4039(00)78466-8.
225 H. Gaspar, A. Cutignano, T. Ferreira, G. Calado, G. Cimino and A. Fontana, J. Nat. Prod., 2008, 71, 2053-2056, DOI: 10.1021/np8004387.

226 B. J. Burreson, P. J. Scheuer, J. Finer and J. Clardy, J. Am. Chem. Soc., 1975, 97, 4763-4764, DOI: 10.1021/ja00849a053.

227 M. R. Hagadone, B. J. Burreson, P. J. Scheuer, J. S. Finer and J. Clardy, Helv. Chim. Acta, 1979, 62, 2484-2894, DOI: 10.1002/hlca.19790620742.

228 N. Fusetani, H. J. Wolstenholme and S. Matsunaga, Tetrahedron Lett., 1990, 31, 5623-5624, DOI: 10.1016/ S0040-4039(00)97915-2.

229 R. A. Edrada, V. Wray and P. Proksch, J. Nat. Prod., 2003, 66, 1512-1514, DOI: 10.1021/np030237j.

230 N. K. Gulavita, E. D. De Silva, M. R. Hagadone, P. Karuso, P. J. Scheuer, G. D. Van Duyne and J. Clardy, J. Org. Chem., 1986, 51, 5136-5139, DOI: 10.1021/jo00376a015.

231 K. E. Kassühlke, B. C. M. Potts and D. J. Faulkner, J. Org. Chem., 1991, 56, 3747-3750, DOI: 10.1021/jo00011a065.

232 T. Okino, E. Yoshimura, H. Hirota and N. Fusetani, Tetrahedron, 1996, 52, 9447-9454, DOI: 10.1016/00404020(96)00481-4.

233 N. Fusetani, H. J. Wolstenholme, K. Shinoda, N. Asai and S. Matsunaga, Tetrahedron Lett., 1992, 33, 6823-6826.

234 A. M. White, G. K. Pierens, T. Skinner-Adams, K. T. Andrews, P. V. Bernhardt, E. H. Krenske, E. Mollo and M. J. Garson, J. Nat. Prod., 2015, 78, 1422-1427, DOI: 10.1021/acs.jnatprod.5b00354.

235 S. Jaisamut, S. Prabpai, C. Tancharoen, S. Yuenyongsawad, S. Hannongbua, P. Kongsaeree and A. Plubrukarn, J. Nat. Prod., 2013, 76, 2158-2161, DOI: 10.1021/np4007074.

236 N. Fusetani, H. J. Wolstenholme and S. Matsunaga, Tetrahedron Lett., 1991, 32, 7291-7294, DOI: 10.1016/00404039(91)80501-V.

237 H. Hirota, T. Okino, E. Yoshimura and N. Fusetani, Tetrahedron, 1998, 54, 13971-13980, DOI: 10.1016/S00404020(98)00867-9.

238 E. J. Dumdei, A. E. Flowers, M. J. Garson and C. J. Moore, Comp. Biochem. Physiol., Part A: Mol. Integr. Physiol., 1997, 118A, 1385-1392, DOI: 10.1016/S0300-9629(97)00051-0.

239 A. D. Wright, Comp. Biochem. Physiol., Part A: Mol. Integr. Physiol., 2003, 134A, 307-313, DOI: 10.1016/S10956433(02)00265-9.

240 E. Manzo, M. L. Ciavatta, M. Gavagnin, E. Mollo, Y.-W. Guo and G. Cimino, J. Nat. Prod., 2004, 67, 1701-1704, DOI: 10.1021/np0400961.

241 E. G. Lyakhova, S. A. Kolesnikova, A. I. Kalinovskii and V. A. Stonik, Chem. Nat. Compd., 2010, 46, 534-538, DOI: 10.1007/s10600-010-9670-x.

242 T. Jomoria, T. Shibutani, P. Ahmadi, T. Suzuka and J. Tanaka, Nat. Prod. Commun., 2015, 10, 1913-1914.

243 N. Fusetani, H. Hiroto, T. Okino, Y. Tomono and E. Yoshimura, J. Nat. Toxins, 1996, 5, 249-259.

244 K. Nishikawa, H. Nakahara, Y. Shirokura, Y. Nogata, E. Yoshimura, T. Umezawa, T. Okino and F. Matsuda, $J$. Org. Chem., 2011, 76, 6558-6573, DOI: 10.1021/jo2008109.

245 N. V. Zhukova, Lipids, 2007, 42, 1169-1175, DOI: $10.1007 /$ s11745-007-3123-8. 
246 A. Alqudahi, S. B. Saad, D. Susanti and N. F. Hadry, Malays. Appl. Biol., 2016, 45, 23-28.

247 J. Tanaka and T. Higa, J. Nat. Prod., 1999, 62, 1339-1340, DOI: $10.1021 / \mathrm{np} 990186 \mathrm{j}$.

248 S. J. Wratten and D. J. Faulkner, Tetrahedron Lett., 1978, 16, 1395-1398, DOI: 10.1016/S0040-4039(01)94554-X.

249 S. J. Wratten, D. J. Faulkner, D. Van Engen and J. Clardy, Tetrahedron Lett., 1978, 16, 1391-1394.

250 S. Carmely, M. Ilan and Y. Kashman, Tetrahedron, 1989, 45, 2193-2200.

251 K. A. Alvi, P. Crews and D. G. Loughhead, J. Nat. Prod., 1991, 54, 1509-1515, DOI: 10.1021/np50078a004.

252 K. A. Alvi, B. M. Peters, L. M. Hunter and P. Crews, Tetrahedron, 1993, 49, 329-336, DOI: 10.1016/S00404020(01)80302-1.

253 A. R. Carroll, B. F. Bowden and J. C. Coll, Aust. J. Chem., 1993, 46, 1229-1234, DOI: 10.1071/CH9931229.

254 J. A. Roesener and P. J. Scheuer, J. Am. Chem. Soc., 1986, 108, 846-847, DOI: 10.1021/ja00264a052.

255 S. M. Parrish, W. Yoshida, B. Yang and P. G. Williams, J. Nat. Prod., 2017, 80, 726-730, DOI: 10.1021/ acs.jnatprod.6b00896.

256 S. Matsunaga, N. Fusetani, K. Hashimoto, K. Koseki and M. Noma, Tennen Yuki Kagobutsu Toronkai Koen Yoshishu, 1985, 27, 375-382.

257 S. Matsunaga, N. Fusetani, K. Hashimoto, K. Koseki and M. Noma, J. Am. Chem. Soc., 1986, 108, 847-849, DOI: 10.1021/ja00264a053.

258 J. R. Pawlik, M. R. Kernan, T. F. Molinski, M. K. Harper and D. J. Faulkner, J. Exp. Mar. Biol. Ecol., 1988, 119, 99-109, DOI: 10.1016/0022-0981(88)90225-0.

259 D. S. Dalisay, E. W. Rogers, A. S. Edison and T. F. Molinski, J. Nat. Prod., 2009, 72, 732-738, DOI: 10.1021/np8007649.

260 S. Matsunaga, N. Fusetani, K. Hashimoto, K. Koseki, M. Noma, H. Noguchi and U. Sankawa, J. Org. Chem., 1989, 54, 1360-1363, DOI: 10.1021/jo00267a024.

261 M. R. Kernan, T. F. Molinski and D. J. Faulkner, J. Org. Chem., 1988, 53, 5014-5020, DOI: 10.1021/jo00256a021.

262 E. Vincent, J. Saxton, C. Baker-Glenn, I. Moal, J. D. Hirst, G. Pattenden and P. E. Shaw, Cell. Mol. Life Sci., 2007, 64, 487-497, DOI: 10.1007/s00018-007-6427-1.

263 Y. Guo, M. Gavagnin, E. Mollo, E. Trivellone and G. Cimino, Tetrahedron Lett. , 1998, 39, 2635-2638, DOI: 10.1016/S00404039(98)00225-1.

264 Y. Tanaka, S. Yamada and M. Sameshima, Nippon Suisan Gakkaishi, 1992, 58, 1549, DOI: 10.2331/suisan.58.1549.

265 R. E. Coman and B. C. L. Weedon, J. Chem. Soc., Perkin Trans. 1, 1975, 2529-2532.

266 W. Zhang, M. Gavagnin, Y.-W. Guo, E. Mollo, M. T. Ghiselin and G. Cimino, Tetrahedron, 2007, 63, 4725-4729, DOI: 10.1016/j.tet.2007.03.082.

267 D. S. Nielsen, H. N. Hoang, R.-J. Lohman, F. Diness and D. P. Fairlie, Org. Lett., 2012, 14, 5720-5723, DOI: 10.1021/ol3027347.

268 E. K. Singh, D. M. Ramsey and S. R. McAlpine, Org. Lett., 2012, 14, 1198-1201, DOI: 10.1021/ol203290n.
269 H. Wahyudi, W. Tantisantisom, X. Liu, D. M. Ramsey, E. K. Singh and S. R. McAlpine, J. Org. Chem., 2012, 77, 10596-10616, DOI: 10.1021/jo3017499.

270 B. Carté and D. J. Faulkner, J. Org. Chem., 1983, 48, 23142318.

271 B. Carté and D. J. Faulkner, J. Chem. Ecol., 1986, 12, 795804.

272 A. C. Granato, J. H. H. L. de Oliveira, M. H. R. Seleghim, R. G. S. Berlinck, M. L. Macedo, A. G. Ferreira, R. M. da Rocha, E. Hajdu, S. Peixinho, C. O. Pessoa, M. O. Moraes and B. C. Cavalcanti, Quim. Nova, 2005, 28, 192-198, DOI: 10.1590/S0100-40422005000200005.

273 A. J. Blackman and C. Li, Aust. J. Chem., 1994, 47, 16251629.

274 A. Franks, P. Haywood, C. Holmstrom, S. Egan, S. Kjelleberg and N. Kumar, Molecules, 2005, 10, 1286-1291.

275 R. Kazlauskas, J. F. Marwood, P. T. Murphy and R. J. Wells, Aust. J. Chem., 1982, 35, 215-217, DOI: 10.1071/CH9820215.

276 S. Matsunaga, N. Fusetani and K. Hashimoto, Experientia, 1986, 42, 84.

277 V. J. Paul, N. Lindquist and W. Fenical, Mar. Ecol.: Prog. Ser., 1990, 59, 109-118.

278 H. H. Wasserman, D. J. Friedland and D. A. Morrison, Tetrahedron Lett., 1968, 641-644, DOI: 10.1016/S00404039(00)75602-4.

279 M. Carbone, C. Irace, F. Costagilola, F. Castelluccio, G. Villani, G. Calado, V. Padula, G. Cimino, J. L. Cervera, R. Santamaria and M. Gavagnin, Bioorg. Med. Chem. Lett., 2010, 20, 2668-2670, DOI: 10.1016/j.bmcl.2010.02.020.

280 N. Lindquist and W. Fenical, Experientia, 1991, 47, 504-506.

281 B. C. Cavalcnti, H. V. N. Júnior, M. H. R. Seleghim, R. G. S. Berlinck, G. M. A. Cunha, M. O. Moraes and C. Pessoa, Chem.-Biol. Interact., 2008, 174, 155-162, DOI: 10.1016/j.cbi.2008.05.029.

282 K. Gustafson and R. J. Anderson, J. Org. Chem., 1982, 47, 2167-2169, DOI: 10.1021/jo00132a036.

283 E. I. Graziani and R. J. Anderson, J. Nat. Prod., 1998, 61, 285-286, DOI: 10.1021/NP970397T.

284 E. I. Graziani and R. J. Andersen, Chem. Commun., 1996, 2377-2378, DOI: 10.1039/cc9960002377.

285 J. Kubanek and R. J. Andersen, Tetrahedron Lett., 1997, 38, 6327-6330, DOI: 10.1016/S0040-4039(97)01455-X.

286 E. Piers, J. M. Chong, K. Gustafson and R. J. Andersen, Can. J. Chem., 1984, 62, 1-5, DOI: 10.1139/v84-001.

287 J. W. McBeth, Comp. Biochem. Physiol., Part B: Biochem. Mol. Biol., 1972, 41, 55-68, DOI: 10.1016/0305-0491(72)90007-7.

288 T. Matsuno, M. Ookubo and T. Komori, J. Nat. Prod., 1985, 48, 606-613, DOI: 10.1021/np50040a015.

289 B. Czeczuga, Hydrobiologia, 1976, 51, 71-75, DOI: 10.1007/ BF00007987.

290 S. Affeld, S. Kehraus, H. Wägele and G. M. König, J. Nat. Prod., 2009, 72, 298-300, DOI: 10.1021/np800583e.

291 N. R. Howe and L. G. Harris, J. Chem. Ecol., 1978, 4, 551561, DOI: $10.1007 /$ BF00988919.

292 M. C. Leal, C. Nunes, D. Alexandre, T. L. Silva, A. Reis, M. T. Dinis and R. Calado, Mar. Biol., 2012, 159, 17451751, DOI: 10.1007/s00227-012-1962-1. 
293 A. Garese, S. Garcia-Matucheski, F. H. Acuna and C. Muniain, Zool. Stud., 2012, 51, 905-912.

294 M. L. Ciavatta, E. Trivellone, G. Villani and G. Cimino, Gazz. Chim. Ital., 1996, 126, 707-710.

295 S. J. Rochfort and R. J. Capon, J. Nat. Prod., 1994, 57, 849851, DOI: 10.1021/np50108a029.

296 R. Martin, S. Hild, P. Walther, K. Ploss, W. Boland and K.-H. Tomaschko, Biol. Bull., 2007, 213, 307-315, DOI: $10.2307 / 25066648$.

297 I. E. Kasheverov, I. V. Shelukhina, D. S. Kudryavtsev, T. N. Makarieva, E. N. Spirova, A. G. Guzii, V. A. Stonik and V. I. Tsetlin, Mar. Drugs, 2015, 13, 1255-1266, DOI: 10.3390/md13031255.

298 W. D. Raverty, R. H. Thomson and T. J. King, J. Chem. Soc., Perkin Trans. 1, 1977, 10, 1204-1211.

299 K. Kondo and J. Nishi, J. Nat. Prod., 1994, 57, 1008-1011, DOI: $10.1021 / \mathrm{np50109a023.}$

300 A. Aiello, F. Borrelli and R. Capasso, Bioorg. Med. Chem. Lett. $\quad 2003, \quad 13, \quad 4481-4483$, DOI: 10.1016/ j.bmcl.2003.08.081.

301 C. Megina, T. Gosliner and J. L. Cervera, Cah. Biol. Mar., 2007, 48, 1-7.

302 M. Carbone, Y. Li, C. Irace, E. Mollo, F. Castelluccio, A. Di Pascale, G. Cimino, R. Santamaria, Y.-W. Guo and M. Gavagnin, Org. Lett., 2011, 13, 2516-2519, DOI: 10.1021/ol200234r.

303 J. T. Brogan, S. L. Stoops and C. W. Lindsley, ACS Chem. Neurosci., 2012, 3, 658-664, DOI: 10.1021/cn300064r.

304 H.-Y. Lin and B. B. Snider, J. Org. Chem., 2012, 77, 48324836, DOI: 10.1021/jo300449n.

305 E. Manzo, D. Pagano, M. Carbone, M. L. Ciavatta and M. Gavagnin, ARKIVOC, 2012, 220-228, DOI: 10.3998/ ark.5550190.0013.919.

306 J. C. Buchanan, B. P. Petersen and S. Chamberland, Tetrahedron Lett., 2013, 54, 6002-6004, DOI: 10.1016/ j.tetlet.2013.08.063.

307 C. V. Maftei, E. Fodor, P. G. Jones, M. H. Franz, G. Kelter, H. Fiebig and I. Neda, Beilstein J. Org. Chem., 2013, 9, 2202-2215, DOI: 10.3762/bjoc.9.259.

308 C.-S. Jiang, Y. Fu, L. Zhang, J.-X. Gong, Z.-Z. Wang, W. Xiao, H.-Y. Zhang and Y.-W. Guo, Bioorg. Med. Chem. Lett., 2015, 25, 216-220, DOI: 10.1016/j.bmcl.2014.11.068.

309 L. Zhang, C.-S. Jiang, L.-X. Gao, J.-X. Gong, Z.-H. Wang, J.-Y. Li, J. Li, X.-W. Li and Y.-W. Guo, Bioorg. Med. Chem. Lett., 2016, 26, 778-781, DOI: 10.1016/j.bmcl.2015.12.097.

310 J. C. Coll, B. F. Bowden, D. M. Tapiolas, R. H. Willis, P. Djura, M. Streamer and L. Trott, Tetrahedron, 1985, 41, 1085-1092, DOI: 10.1016/S0040-4020(01)96476-2.

311 M. Slattery, C. Avila, J. Starmer and V. J. Paul, J. Exp. Mar. Biol. Ecol., 1998, 226, 33-49, DOI: 10.1016/S0022-0981(97) 00240-2.

312 R. A. Edrada, V. Wray, L. Witte, L. van Ofwegen and P. Proksch, Z. Naturforsch., C: J. Biosci., 2000, 55, 82-86, DOI: 10.1515/znc-2000-1-216.

313 A. Bogdanov, C. Hertzer, S. Kehraus, S. Nietzer, S. Rohde, P. J. Schupp, H. Waegele and G. M. König, J. Nat. Prod., 2016, 79, 611-615, DOI: 10.1021/acs.jnatprod.5b00860.
314 A. S. R. Anjaneyulu, P. M. Gowri, M. J. R. V. Venugopal, P. Sarada, M. V. R. K. Murthy, G. V. Rao, P. S. N. Murthy, C. V. Rao and G. Kumar, J. Indian Chem. Soc., 1999, 76, 651-659.

315 M. Sugano, T. Shindo, A. Sato, Y. Iijima, T. Oshima, H. Kuwano and T. Hata, J. Org. Chem., 1990, 55, 58035804, DOI: 10.1021/jo00310a001.

316 S.-C. Mao, M. Gavagnin, E. Mollo and Y.-W. Guo, Biochem. Syst. Ecol., 2011, 39, 408-411, DOI: 10.1016/ j.bse.2011.05.018.

317 D. Chen, W. Cheng, D. Liu, L. van Ofwegen, P. Proksch and W. Lin, Tetrahedron Lett., 2014, 55, 3077-3082, DOI: 10.1016/j.tetlet.2014.03.132.

318 A. Guerriero, M. D'Ambrosio and F. Pietra, Helv. Chim. Acta, 1987, 70, 984-991, DOI: 10.1002/hlca.19870700408.

319 A. Guerriero, M. D'Ambrosio and F. Pietra, Helv. Chim. Acta, 1988, 71, 472-485, DOI: 10.1002/hlca.19880710221.

320 A. Guerriero, M. D'Ambrosio and F. Pietra, Helv. Chim. Acta, 1990, 73, 277-283, DOI: 10.1002/hlca.19900730206.

321 W. Zhang, M. Gavagnin, Y.-W. Guo, E. Mollo and G. Cimino, Chin. J. Org. Chem., 2006, 26, 1667-1672.

322 R. K. Okuda, D. Klein, R. B. Kinnel, M. Li and P. J. Scheuer, Pure Appl. Chem., 1982, 54, 1907-1914, DOI: 10.1351/ pac198254101907.

323 G. Cimino, S. De Rosa, S. De Stefano and G. Sodano, Tetrahedron Lett., 1980, 21, 3303-3304, DOI: 10.1016/ S0040-4039(00)78673-4.

324 R. Kuhn, J. Stene and N. A. Sorensen, Ber. Dtsch. Chem. Ges. $B, 1939,72 B, 1688-1701$.

325 T. Barsby, R. G. Linington and R. J. Anderson, Chemoecology, 2002, 12, 199-202, DOI: 10.1007/ PL00012669.

326 G. Cimino, A. Crispino, V. Di Marzo, G. Sodano, A. Spinella and G. Villani, Experientia, 1991, 47, 56-60.

327 S. W. Ayer and R. J. Andersen, Experientia, 1983, 39, 255256, DOI: $10.1007 / \mathrm{BF} 01955289$.

328 D. Barnard and L. Bateman, J. Chem. Soc., 1950, 932-936, DOI: $10.1039 / J R 9500000932$.

329 J. L. Sevigny, L. E. Kirouac, W. K. Thomas, J. S. Ramsdell, K. E. Lawlor, O. Sharifi, S. Grewal, C. Baysdorfer, K. Curr, A. A. Naimie, K. Okamoto, J. A. Murray and J. M. Newcomb, PLoS One, 2015, 10, e0127519, DOI: 10.1371/journal.pone.0127519.

330 J. L. Sevigny, L. E. Kirouac, W. K. Thomas, J. S. Ramsdell, K. E. Lawlor, O. Sharifi, S. Grewal, C. Baysdorfer, K. Curr, A. A. Naimie, K. Okamoto, J. A. Murray and J. M. Newcomb, PLoS One, 2015, 10, e0132861, DOI: 10.1371/journal.pone.0132861.

331 G. Cimino, A. Spinella and G. Sodano, Tetrahedron Lett., 1989, 30, 3589-3592, DOI: 10.1016/S0040-4039(00)99449-8.

332 G. Cimino, A. Crispino, V. Di Marzo, A. Spinella and G. Sodano, J. Org. Chem., 1991, 56, 2907-2911, DOI: 10.1021/jo00008a056.

333 K. Tsuboi, Y. Sugimoto and A. Ichikawa, Prostaglandins Other Lipid Mediators, 2002, 68-69, 535-556, DOI: 10.1016/S0090-6980(02)00054-0. 
334 M. L. Ciavatta, E. Manzo, E. Mollo, C. A. Mattia, C. Tedesco, C. Irace, Y.-W. Guo, X.-B. Li, G. Cimino and M. Gavagnin, J. Nat. Prod., 2011, 74, 1902-1907, DOI: 10.1021/np200342k.

335 T. S. Sousa, G. Nuzzo, M. C. M. Torres, N. P. Lopes, A. Cutignano, P. C. Jimenez, E. A. Santos, B. A. Gomes, A. Sardo, O. D. L. Pessoa, L. V. Costa-Lotufo and A. Fontana, Rev. Bras. Farmacogn., 2015, 25, 600-604, DOI: 10.1016/j.bjp.2015.08.010.

336 M. Ishibashi, M. Takahashi and J. Kobayashi, J. Org. Chem., 1995, 60, 6062-6066, DOI: 10.1021/jo00124a015.

337 D. E. Williams and R. J. Anderson, Can. J. Chem., 1987, 65, 2244-2247, DOI: 10.1139/v87-374.

338 D. E. Williams, R. J. Anderson, G. Van Duyne and J. Clardy, J. Org. Chem., 1987, 52, 332-335, DOI: 10.1021/jo00379a002.

339 M. G. Missakian, B. J. Burreson and P. J. Scheuer, Tetrahedron, 1975, 31, 2513-2515, DOI: 10.1016/00404020(75)80262-6.

340 S. J. Wratten, W. Fenical, D. J. Faulkner and J. C. Wekell, Tetrahedron Lett., 1977, 18, 1559-1562, DOI: 10.1016/ S0040-4039(01)93102-8.

341 G. Cronin, M. E. Hay, W. Fenical and N. Lindquist, Mar. Ecol.: Prog. Ser., 1995, 119, 177-189, DOI: 10.3354/ meps119177.

342 J. B. McClintock, B. J. Baker, M. Slattery, J. N. Heine, P. J. Bryan, W. Yoshida, M. T. Davies- Coleman and D. J. Faulkner, J. Chem. Ecol., 1994, 20, 3361-3372, DOI: 10.1007/BF02033732.

343 A. Cutignano, J. Moles, C. Avila and A. Fontana, J. Nat. Prod., 2015, 78, 1761-1764, DOI: 10.1021/ acs.jnatprod.5b00378.

344 J. Moles, H. Wagele, A. Cutignano, A. Fontana and C. Avila, Mar. Biol., 2016, 163, 1-11, DOI: 10.1007/s00227-016-28310.

345 J. Pika and D. J. Faulkner, Tetrahedron, 1994, 50, 3065-3070, DOI: 10.1016/S0040-4020(01)81106-6.

346 K. L. McPhail, M. T. Davies-Coleman and J. Starmer, J. Nat. Prod., 2001, 64, 1183-1190, DOI: 10.1021/np010085x.

347 C. E. Whibley, K. L. McPhail, R. A. Keyzers, M. F. Maritz, V. D. Leaner, M. J. Birrer, M. T. Davies-Coleman and D. T. Hendricks, Mol. Cancer Ther., 2007, 6, 2535-2543, DOI: 10.1158/1535-7163.MCT-06-0760.

348 A. Putz, S. Kehraus, G. Diaz-Agras, H. Waegele and G. M. Koenig, Eur. J. Org. Chem., 2011, 3733-3737, S3733, DOI: $10.1002 /$ ejoc.201100347.

349 J. Moles, H. Waegele, M. Ballesteros, A. Pujals, G. Uhl and C. Avila, PLoS One, 2016, 11, e0157941, DOI: 10.1371/ journal.pone.0157941.

350 G. Sodano and A. Spinella, Tetrahedron Lett., 1986, 27, 2505-2508, DOI: 10.1016/S0040-4039(00)84569-4.

351 J. Wang, M. R. Prinsep, D. P. Gordon, M. J. Page and B. R. Copp, J. Nat. Prod., 2015, 78, 530-533, DOI: 10.1021/ np500752y.

352 WoRMS, http://www.marinespecies.org/aphia.php? $\mathrm{p}=$ taxdetails\&id $=834002$, accessed 12 June 2017.

353 G. Inglis, N. Gust, I. Fitridge, O. Floerl, C. Woods, B. Hayden and G. Fenwick, Port of Tauranga: Baseline survey for non-indigenous marine species, Ministry of
Agriculture and Forestry Biosecurity, New Zealand: Wellington, NZ, 2005, p. 23.

354 OPK, http://opistobranquis.info/en/guia/nudibranchia/ dexiarchia/unassigned-cladobranchia/janolus-cristatus/ \#gsc.tab=0, accessed 29 July 2017.

355 L. Dean, M. Prinsep and R. Fairweather, Chemical Theft: The Sequestration of Natural Products by New Zealand Nudibranchs from their Bryozoan Prey, in NZIC-16, The New Zealand Institute of Chemistry Conference, Queenstown, New Zealand, August, 2016, pp. 21-24, http://www.nzic16.org/.

356 D. Obermann, U. Bickmeyer and H. Wägele, Toxicon, 2012, 60, 1108-1116, DOI: 10.1016/j.toxicon.2012.08.003.

357 H. Wägele and G. Johnsen, Org. Divers. Evol., 2001, 1, 193210, DOI: 10.1078/1439-6092-00016.

358 I. Burghardt, K. Stemmer and H. Wägele, Org. Divers. Evol., 2008, 8, 66-76, DOI: 10.1016/j.ode.2007.01.001.

359 WoRMS, http://www.marinespecies.org/aphia.php? $\mathrm{p}=$ taxdetails\&id $=581809$, accessed 19 May, 2017.

360 WoRMS, http://www.marinespecies.org/aphia.php? $\mathrm{p}=$ taxdetails\&id $=558499$, accessed $11^{\text {th }}$ May 2017.

361 WoRMS, http://www.marinespecies.org/aphia.php? $\mathrm{p}=$ taxdetails\&id $=558620$, accessed 5 October 2017.

362 WoRMS, http:/www.marinespecies.org/aphia.php? $\mathrm{p}=$ taxdetails\&id=565620, accessed 15 May 2017.

363 WoRMS, http:/www.marinespecies.org/aphia.php? $\mathrm{p}=$ taxdetails\&id $=597348$, accessed $11^{\text {th }}$ May 2017.

364 WoRMS, http://www.marinespecies.org/aphia.php? $\mathrm{p}=$ taxdetails\&id=597352, accessed 15 May 2017.

365 WoRMS, http:/www.marinespecies.org/aphia.php? $\mathrm{p}=$ taxdetails\&id=558218, accessed 28 July 2017.

366 WoRMS, http://www.marinespecies.org/aphia.php? $\mathrm{p}=$ taxdetails\&id $=597335$, accessed $11^{\text {th }}$ May 2017.

367 WoRMS, http:/www.marinespecies.org/aphia.php? $\mathrm{p}=$ taxdetails\&id $=597336$, accessed 15 May 2017.

368 WoRMS, http:/www.marinespecies.org/aphia.php? $\mathrm{p}=$ taxdetails\&id $=597358$, accessed $11^{\text {th }}$ May 2017.

369 WoRMS, http://www.marinespecies.org/aphia.php? $\mathrm{p}=$ taxdetails\&id $=558319$, accessed 28 July 2017.

370 WoRMS, http://www.marinespecies.org/aphia.php? $\mathrm{p}=$ taxdetails\&id=597339, accessed 15 May 2017.

371 WoRMS, http://www.marinespecies.org/aphia.php? $\mathrm{p}=$ taxdetails\&id=597403, accessed 15 May 2017.

372 WoRMS, http://www.marinespecies.org/aphia.php? $\mathrm{p}=$ taxdetails\&id $=597451$, accessed 15 May 2017.

373 WoRMS, http://www.marinespecies.org/aphia.php? $\mathrm{p}=$ taxdetails\&id=209601, accessed 28 July 2017.

374 WoRMS, http://www.marinespecies.org/aphia.php? $\mathrm{p}=$ taxdetails\&id=597452, accessed 15 May 2017.

375 WoRMS, http:/www.marinespecies.org/aphia.php? $\mathrm{p}=$ taxdetails\&id=597406, accessed 15 May 2017.

376 WoRMS, http://www.marinespecies.org/aphia.php? $\mathrm{p}=$ taxdetails\&id $=597365$, accessed 14 June 2017.

377 WoRMS, http://www.marinespecies.org/aphia.php? $\mathrm{p}=$ taxdetails\&id $=597367$, accessed 28 July 2017.

378 WoRMS, http://www.marinespecies.org/aphia.php? $\mathrm{p}=$ taxdetails\&id=597341, accessed 15 May 2017. 
379 WoRMS, http://www.marinespecies.org/aphia.php? $\mathrm{p}=$ taxdetails\&id=597380, accessed 11 May, 2017.

380 WoRMS, http://www.marinespecies.org/aphia.php? $\mathrm{p}=$ taxdetails\&id $=597343$, accessed 15 May 2017.

381 WoRMS, http://www.marinespecies.org/aphia.php? $\mathrm{p}=$ taxdetails\&id $=597374$, accessed 14 June 2017.

382 WoRMS, http://www.marinespecies.org/aphia.php? $\mathrm{p}=$ taxdetails\&id=559960, accessed 15 May 2017.

383 WoRMS, http://www.marinespecies.org/aphia.php? $\mathrm{p}=$ taxdetails\&id $=884441$, accessed 28 July, 2017.

384 WoRMS, http://www.marinespecies.org/aphia.php? $\mathrm{p}=$ taxdetails\&id $=597315$, accessed 11 May 2017 .

385 WoRMS, http://www.marinespecies.org/aphia.php? $\mathrm{p}=$ taxdetails\&id $=597398$, accessed 11 May, 2017.

386 WoRMS, http://www.marinespecies.org/aphia.php? $\mathrm{p}=$ taxdetails\&id=139143, accessed 11 May, 2017.

387 WoRMS, http://www.marinespecies.org/aphia.php? $\mathrm{p}=$ taxdetails\&id $=597530$, accessed 11 May, 2017.

388 WoRMS, http://www.marinespecies.org/aphia.php? $\mathrm{p}=$ taxdetails\&id $=597522$, accessed 11 May, 2017.

389 WoRMS, http://www.marinespecies.org/aphia.php? $\mathrm{p}=$ taxdetails\&id $=597514$, accessed 15 May 2017.

390 WoRMS, http://www.marinespecies.org/aphia.php? $\mathrm{p}=$ taxdetails\&id $=597520$, accessed 15 May 2017.

391 WoRMS, http://www.marinespecies.org/aphia.php? $\mathrm{p}=$ taxdetails\&id $=597543$, accessed 15 May 2017.

392 WoRMS, http:/www.marinespecies.org/aphia.php? $\mathrm{p}=$ taxdetails\&id $=558680$, accessed 21 September 2017.

393 WoRMS, http://www.marinespecies.org/aphia.php? $\mathrm{p}=$ taxdetails\&id=597820, accessed 15 May 2017.

394 WoRMS, http://www.marinespecies.org/aphia.php? $\mathrm{p}=$ taxdetails\&id $=597823$, accessed 15 May 2017.

395 WoRMS, http://www.marinespecies.org/aphia.php? $\mathrm{p}=$ taxdetails\&id $=558649$, accessed 15 May 2017.

396 WoRMS, http://www.marinespecies.org/aphia.php? $\mathrm{p}=$ taxdetails\&id=597827, accessed 15 May 2017.

397 WoRMS, http://www.marinespecies.org/aphia.php? $\mathrm{p}=$ taxdetails\&id $=597533$, accessed 15 May 2017.

398 WoRMS, http://www.marinespecies.org/aphia.php? $\mathrm{p}=$ taxdetails\&id $=597534$, accessed 15 May 2017.

399 WoRMS, http://www.marinespecies.org/aphia.php? $\mathrm{p}=$ taxdetails\&id=597536, accessed 15 May 2017.

400 WoRMS, http://www.marinespecies.org/aphia.php? $\mathrm{p}=$ taxdetails\&id $=597522$, accessed 15 May 2017.

401 WoRMS, http://www.marinespecies.org/aphia.php? $\mathrm{p}=$ taxdetails\&id $=597538$, accessed 15 May 2017.
402 WoRMS, http://www.marinespecies.org/aphia.php? $\mathrm{p}=$ taxdetails\&id=558646, accessed 28 July 2017.

403 WoRMS, http:/www.marinespecies.org/aphia.php? $\mathrm{p}=$ taxdetails\&id $=536910$, accessed 28 July 2017.

404 WoRMS, http:/www.marinespecies.org/aphia.php? $\mathrm{p}=$ taxdetails\&id $=594422$, accessed $9^{\text {th }}$ May 2017.

405 WoRMS, http:/www.marinespecies.org/aphia.php? $\mathrm{p}=$ taxdetails\&id $=536827$, accessed $9^{\text {th }}$ May 2017.

406 WoRMS, http:/www.marinespecies.org/aphia.php? $\mathrm{p}=$ taxdetails\&id $=872299$, accessed $9^{\text {th }}$ May 2017.

407 WoRMS, http://www.marinespecies.org/aphia.php? $\mathrm{p}=$ taxdetails\&id $=581816$, accessed $9^{\text {th }}$ May 2017.

408 WoRMS, http://www.marinespecies.org/aphia.php? $\mathrm{p}=$ taxdetails\&id $=581817$, accessed 15 May 2017.

409 WoRMS, http://www.marinespecies.org/aphia.php? $\mathrm{p}=$ taxdetails\&id=181228, accessed 15 May 2017.

410 WoRMS, http://www.marinespecies.org/aphia.php? $\mathrm{p}=$ taxdetails\&id=411132, accessed 15 May 2017.

411 WoRMS, http://www.marinespecies.org/aphia.php? $\mathrm{p}=$ taxdetails\&id=599485, accessed 23 May 2017.

412 WoRMS, http://www.marinespecies.org/aphia.php? $\mathrm{p}=$ taxdetails\&id $=536695$, accessed $9^{\text {th }}$ May 2017.

413 WoRMS, http:/www.marinespecies.org/aphia.php? $\mathrm{p}=$ taxdetails\&id $=536574$, accessed $9^{\text {th }}$ May 2017.

414 WoRMS, http:/www.marinespecies.org/aphia.php? $\mathrm{p}=$ taxdetails\&id $=531260$, accessed 30 May 2017 .

415 WoRMS, http:/www.marinespecies.org/aphia.php? $\mathrm{p}=$ taxdetails\&id $=730410$, accessed 28 April 2017.

416 WoRMS, http:/www.marinespecies.org/aphia.php? $\mathrm{p}=$ taxdetails\&id $=456805$, accessed 28 April 2017.

417 WoRMS, http://www.marinespecies.org/aphia.php? $\mathrm{p}=$ taxdetails\&id $=457000$, accessed 1 June 2017.

418 WoRMS, http:/www.marinespecies.org/aphia.php? $\mathrm{p}=$ taxdetails\&id=204424, accessed 28 April 2017.

419 WoRMS, http://www.marinespecies.org/aphia.php? $\mathrm{p}=$ taxdetails\&id=890630, accessed 21 September 2017.

420 WoRMS, http://www.marinespecies.org/aphia.php? $\mathrm{p}=$ taxdetails\&id $=412595$, accessed 1 June 2017.

421 WoRMS, http://www.marinespecies.org/aphia.php? $\mathrm{p}=$ taxdetails\&id $=558400$, accessed 1 June 2017.

422 WoRMS, http://www.marinespecies.org/aphia.php? $\mathrm{p}=$ taxdetails\&id $=851422$, accessed 28 July 2017 .

423 WoRMS, http://www.marinespecies.org/aphia.php? $\mathrm{p}=$ taxdetails\&id $=572093$, accessed 27 April 2017. 